\title{
Start Selective and Rigidify: The Discovery Path toward a Next Generation of EGFR Tyrosine Kinase Inhibitors
}

Harald Engelhardt, ${ }^{*},, \| \odot$ Dietrich Böse, ${ }^{\dagger, \S, \|}$ Mark Petronczki, ${ }^{\dagger}$ Dirk Scharn, ${ }^{\dagger}$ Gerd Bader, ${ }^{\dagger}$ Anke Baum, Andreas Bergner, ${ }^{\dagger}$ Eugene Chong, ${ }^{\ddagger}$ Sandra Döbel, ${ }^{\dagger}$ Georg Egger, ${ }^{\dagger}$ Christian Engelhardt, ${ }^{\dagger}$ Peter Ettmayer, ${ }^{\dagger}$ Julian E. Fuchs, ${ }^{\dagger}$ Thomas Gerstberger, ${ }^{\dagger}$ Nina Gonnella, ${ }^{\ddagger}$ A Andreas Grimm, ${ }^{\dagger}$ Elisabeth Grondal,,$^{\dagger}$ Nizar Haddad, ${ }^{\ddagger}$ Barbara Hopfgartner, ${ }^{\dagger}$ Roland Kousek, ${ }^{\dagger}$ Mariusz Krawiec, ${ }^{\dagger}$ Monika Kriz, ${ }^{\dagger}$ Lyne Lamarre, ${ }^{\dagger}$ Joyce Leung, ${ }^{\ddagger}$ Moriz Mayer, ${ }^{\dagger}$ Nitinchandra D. Patel, ${ }^{\ddagger 0}$ Biljana Peric Simov, ${ }^{\dagger}$ Jonathan T. Reeves, ${ }^{\ddagger}$ Renate Schnitzer, ${ }^{\dagger}$ Andreas Schrenk, ${ }^{\dagger}$ Bernadette Sharps, ${ }^{\dagger}$ Flavio Solca, ${ }^{\dagger}$ Heinz Stadtmüller, ${ }^{\dagger}$ Zhulin Tan, ${ }^{\ddagger}$ Tobias Wunberg, ${ }^{\dagger}$ Andreas Zoephel, ${ }^{\dagger}$ and Darryl B. McConnell ${ }^{\dagger}$

\footnotetext{
${ }^{\dagger}$ Boehringer Ingelheim RCV GmbH \& Co KG, Dr-Boehringer-Gasse 5-11, Vienna 1120, Austria

${ }^{\ddagger}$ Boehringer Ingelheim Pharmaceuticals, Inc., 900 Ridgebury Road, Ridgefield, Connecticut 06877, United States
}

Supporting Information

ABSTRACT: The epidermal growth factor receptor (EGFR), when carrying an activating mutation like del19 or L858R, acts as an oncogenic driver in a subset of lung tumors. While tumor responses to tyrosine kinase inhibitors (TKIs) are accompanied by marked tumor shrinkage, the response is usually not durable. Most patients relapse within two years of therapy often due to acquisition of an additional mutation in EGFR kinase domain that confers resistance to TKIs. Crucially, oncogenic EGFR harboring both resistance mutations, T790M and C797S, can no longer be inhibited by currently approved EGFR TKIs. Here, we describe the discovery of BI-4020, which is a noncovalent, wild-type EGFR sparing, macrocyclic TKI. BI-4020 potently inhibits the above-described EGFR variants and induces tumor regressions in a cross-resistant EGFR $^{\text {del19 T790M C797S }}$ xenograft model. Key was the identification of a highly selective but moderately potent benzimidazole followed by complete rigidification of the molecule through macrocyclization.

\section{INTRODUCTION}

Kinases are one of the most successfully pursued drug target families with more than 50 kinase inhibitors approved by the FDA to date. ${ }^{1}$ Despite this success, discovering kinase inhibitors with a sufficiently high degree of kinome selectivity and hence tolerability remains a significant challenge to medicinal chemists. ${ }^{2,3}$ This challenge is exacerbated in oncology by the emergence of drug resistance, which requires next generation inhibitors that are able to inhibit both primary and resistant oncogenic clones while maintaining kinome selectivity. ${ }^{4-7}$ New approaches for the discovery of highly selective kinase inhibitors have emerged such as the screening of libraries of kinase inhibitors with intrinsic selectivity profiles $^{8,9}$ and macrocyclization of kinase inhibitors. ${ }^{10,11}$

The epidermal growth factor receptor (EGFR) is a receptor tyrosine kinase that transduces mitogenic signals. Mutations in the EGFR gene are found in approximately $12-47 \%$ of nonsmall cell lung cancer (NSCLC) tumors with adenocarcinoma histology. ${ }^{12}$ The two most frequent EGFR alterations found in NSCLC tumors are short in-frame deletions in exon
19 (del19) of the EGFR gene and L858R, a single missense mutation in exon 21. ${ }^{13}$ These two mutations cause ligandindependent EGFR activation and are collectively referred to as $\mathrm{EGFR}^{\mathrm{M}+}$. Del19 and L858R mutations in EGFR sensitize NSCLC tumors to the treatment with EGFR tyrosine kinase inhibitors (TKIs). Clinical experience shows that the objective response rate in lung cancer patients carrying tumors with $\mathrm{EGFR}^{\mathrm{M}+}$ is approximately $60-85 \%$ in first line with the first, second, and third generation EGFR TKIs erlotinib, gefitinib, afatinib, and osimertinib (see structures in Figure 1). ${ }^{14-17}$ These responses demonstrate that EGFR ${ }^{\mathrm{M}+}$ NSCLC cells and tumors depend on oncogenic EGFR activity for survival and proliferation, establishing del19 or L858R mutated EGFR variants as a validated drug targets and predictive biomarkers for the treatment of NSCLC.

While tumor responses are accompanied by marked tumor shrinkage in patients, the response is usually not durable, and

Received: August 14, 2019

Published: November 5, 2019 


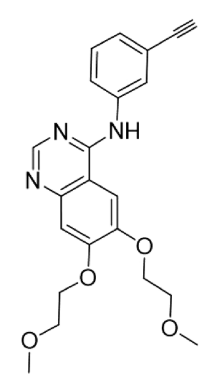

Erlotinib $1^{\text {st }}$ generation<smiles>COc1cc2ncnc(Nc3ccc(F)c(Cl)c3)c2cc1OCCCN1CCOCC1</smiles>

Gefitinib $1^{\text {st }}$ generation<smiles>CN(C)C/C=C/C(=O)Nc1cc2c(Nc3ccc(F)c(Cl)c3)ncnc2cc1O[C@H]1CCOC1</smiles>

Afatinib $2^{\text {nd }}$ generation<smiles>C=CC(=O)Nc1cc(Nc2nccc(-c3cn(C)c4ccccc34)n2)c(OC)cc1N(C)CCN(C)C</smiles>

Osimertinib $3^{\text {rd }}$ generation

Figure 1. Overview of selected approved first, second, and third generation EGFR TKIs.<smiles>[R17]CC(=O)Nc1ccc(OC)c(Nc2ccc(-c3nc(CCCO)n[nH]3)cc2-c2ccc(F)cc2)c1</smiles>

Biochemical Potency: ${ }^{33}$ $\mathrm{IC}_{50}$ EGFR $^{\mathrm{L} 858 \mathrm{R}}$ T790M C7975 $8 \mathrm{nM}$

Selectivity: ${ }^{33}$

wt-sparing ratio (biochem.): $<1$<smiles>[R4]C(C)c1nc2cnc(Nc3ccnc(N4CCC(F)C(O)C4)n3)cc2n1C(C)(C)C</smiles>

Biomarker Potency (BaF3 cells):* $\mathrm{IC}_{50}$ p-EGFR del19 T790M C797s.

$13 \mathrm{nM}$<smiles>[R10][R17]NC(=O)CC</smiles>

Anti-Proliferation Potency (BaF3 cells): ${ }^{37}$

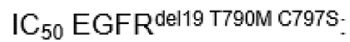

$320 \mathrm{nM}$

Selectivity: ${ }^{37}$

wt-sparing ratio (biochem.):

$<1$

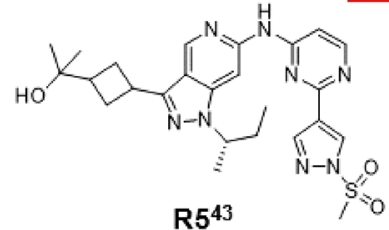

Biomarker Potency (PC-9 cells): ${ }^{43}$

$\mathrm{IC}_{50}$ p-EGFR del19.

$33 \mathrm{nM}$

Anti-Proliferation Potency (BaF3 cells): $\mathrm{IC}_{50}$ EGFR del19 T790M C797S: $\quad 200 \mathrm{nM}$

Selectivity:* wt-sparing ratio (proliferation):

6

Selectivity: ${ }^{43}$

wt-sparing ratio (biomarker):

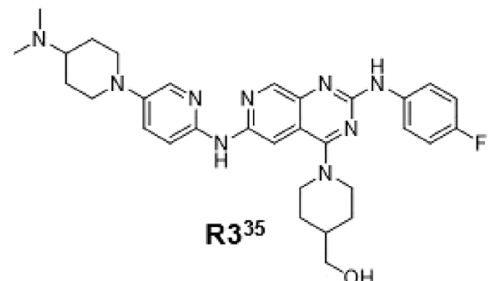

Biochemical Potency: 35 OH $\mathrm{IC}_{50}$ EGFR L858R T790M C7975: $7 \mathrm{nM}$

Selectivity: $:^{35}$

wt-sparing ratio (biochem.): $\quad 1.4$<smiles>N#Cc1ccc(O)c(-c2nc(NCc3cnccn3)c3ccccc3n2)c1</smiles>

$\mathrm{R6}^{42}$

Biochemical Potency: 42

$I_{50}$ p-EGFR del19 T790M C797s.

$18 \mathrm{nM}$

Biomarker Potency (BaF3 cells):*

$I_{50}$ p-EGFR del19 T790M C797s $\quad 1,200 \mathrm{nM}$

Selectivity: $:^{42}$

wt-sparing ratio (biochemical): $>1,000$

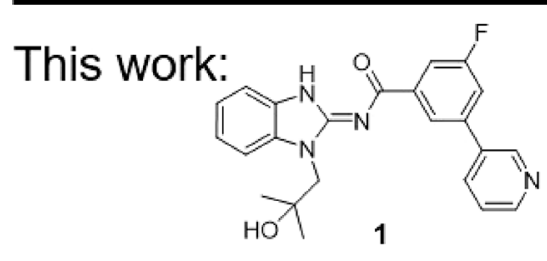

Biomarker Potency (BaF3 cells):* $I_{50}$ p-EGFR del19 T790M C797s: 790 nM

Anti-Proliferation Potency (BaF3 cells):* $\mathrm{IC}_{50} \mathrm{EGFR}^{\text {del19 T790M C7975: }} 300 \mathrm{nM}$

Selectivity:*

wt-sparing ratio (biochem.): $>400$
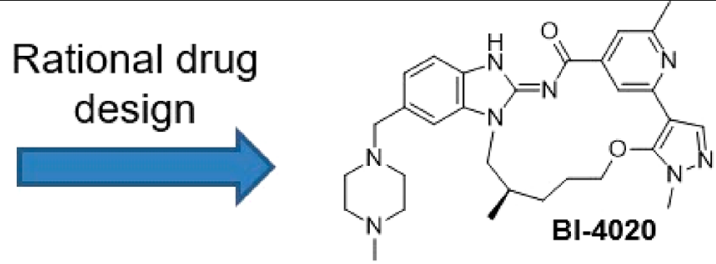

Biomarker Potency (BaF3 cells):*

$\mathrm{IC}_{50}$ p-EGFR del19 T790M C797S. $0.6 \mathrm{nM}$

Anti-Proliferation Potency (BaF3 cells):* $\mathrm{IC}_{50}$ EGFR $^{\text {del19 T790M C797s: }} \quad 0.2 \mathrm{nM}$

Selectivity:

wt-sparing ratio (proliferation): $>400 \quad *$ in house data

Figure 2. Overview of selected published EGFR inhibitors with inhibition data $\left(\mathbf{R} \mathbf{1}=\mathbf{3 1 \mathbf { b }} ;{ }^{33} \mathbf{R} \mathbf{2}=\mathbf{J N D} 3229 ;{ }^{37} \mathbf{R} \mathbf{3}=\mathbf{B} 30 ;{ }^{35} \mathbf{R 4}=\mathbf{4 2} ;{ }^{39} \mathbf{R 5}=\mathbf{2 1} ;{ }^{43}\right.$ and $\mathbf{R} 6=1 \mathbf{1}^{42}$ ). Compound 1 serves as a starting point for this work, and BI-4020 demonstrates the superiority of the compounds reported by this work as compared to state of the art. 
Table 1. SAR for the Open-Chain Aminobenzimidazoles 1-5

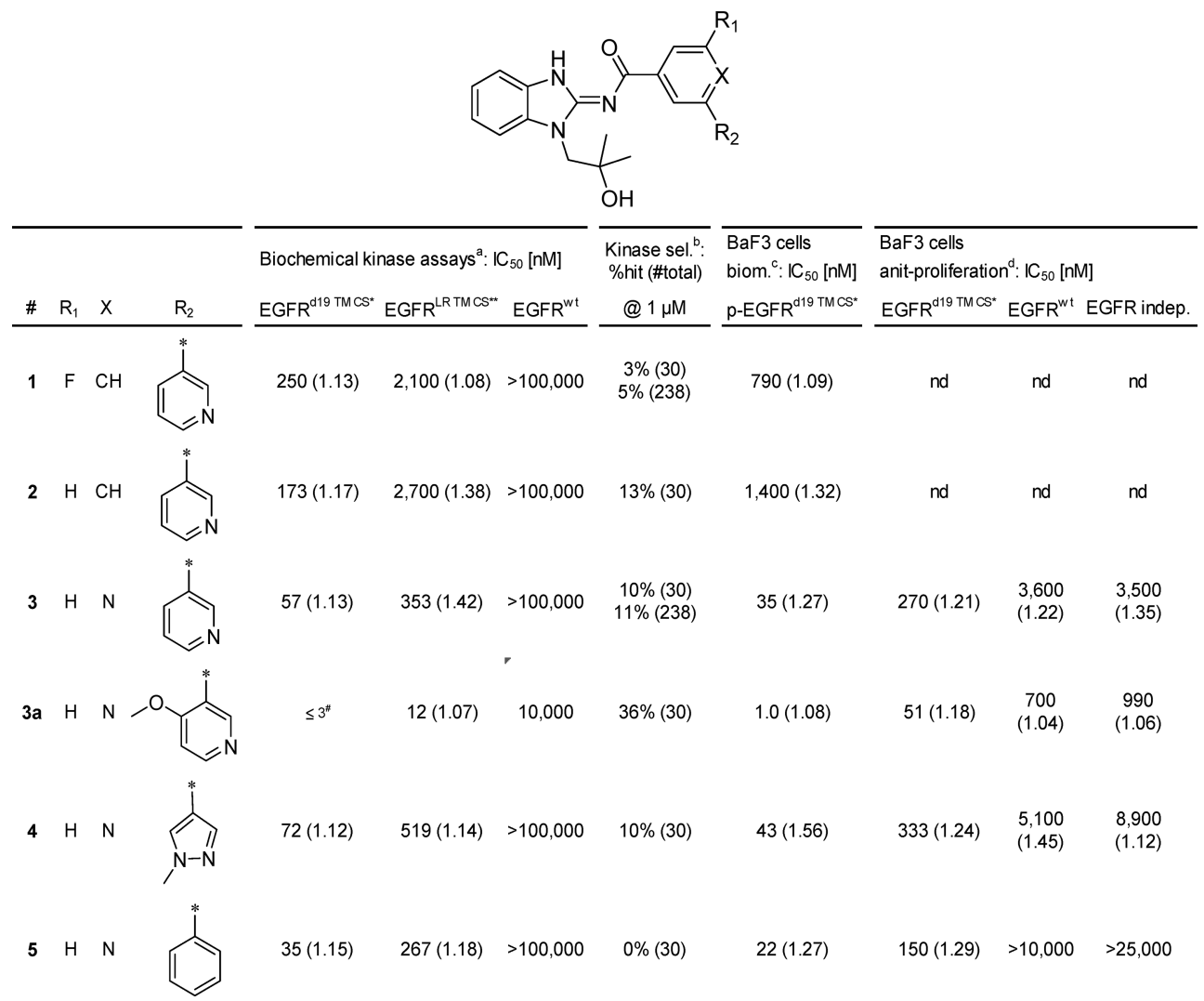

${ }^{a}$ Data are reported as geometric mean of at least three independent measurements, and in brackets is the geometric standard deviation as multiplicative factor given. Biochemical kinase assay using different EGFR variants, which measures the inhibitory effect of compounds on the phosphorylation activity of EGFR enzyme forms on poly-GT substrate in the presence of ATP. *: EGFR ${ }^{\text {d19 TM CS }}$ means EGFR $^{\text {del19 T790M C7975 }}$ **: EGFR $^{\text {LR TM CS }}$ means EGFR ${ }^{\mathrm{L} 858 \mathrm{R} \text { T790M C797S }}$. \#: Activity of compound at or below assay wall (assay wall around $3 \mathrm{nM}$ due to enzyme concentration/ activity and substrate concentration). ${ }^{b}$ Kinase selectivity was determined using the "SelectScreen Kinase Profiling Services" from ThermoFisher.

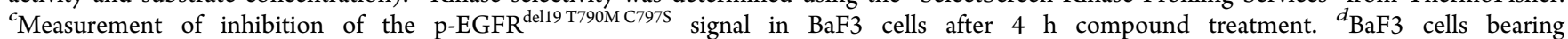
EGFR $^{\text {del19 T790M C797S }}$ protein were treated for 3 days with compound, the effect on proliferation was measured; nd means not determined.

most patients relapse within $9.2-14.7$ months of treatment with first and second generation EGFR TKIs. ${ }^{14-18}$ The most prominent molecular resistance mechanism associated with disease progression in $50-70 \%$ of patients treated with first and second generation EGFR inhibitors is the acquisition of a secondary mutation in EGFR, the gatekeeper mutation T790M. ${ }^{19,20}$ This mutation attenuates the inhibitory activity of first and second generation TKIs in cellular assays. EGFR wild-type sparing covalent third generation EGFR TKIs, such as osimertinib, have been developed that effectively inhibit the primary EGFR mutations del19 and L858R independent of the presence or absence of the secondary T790M resistance mutation. $^{21,22}$

While osimertinib in second line treatment of EGFR $\mathrm{M}^{+}$ T790M-positive NSCLC patients demonstrates clear clinical efficacy, ${ }^{23,24}$ disease progression occurs after an average duration of 10 months. ${ }^{24}$ Recent data suggest that $20-40 \%$ of second line patients relapsing on osimertinib $\mathrm{TKI}^{25-29}$ acquire a tertiary EGFR mutation at the cysteine residue (C797S) required for covalent inhibitor binding. ${ }^{21,22}$ Crucially, the EGFR del19/L858R T790M C797S cis mutant kinase variant that emerges in second line patients progressing on osimertinib $^{25-29}$ can no longer be inhibited by any of the approved first, second, or third generation EGFR TKIs. ${ }^{27}$ While the EGFR resistance mutation spectrum after first line osimertinib treatment has not been extensively studied, first available data also suggest the emergence of the C797S mutation. ${ }^{30}$ Hence, the next generation of EGFR TKIs should (a) be highly active against most common EGFR activation mutation del19, (b) not be susceptible to the most common resistance mutations T790M and/or C797S, (c) have low inhibition of EGFR ${ }^{\text {wt }}$ to avoid on-target toxicities such as rash and diarrhea, and (d) be highly selective across the human kinome.

Recently, a number of potent EGFR inhibitors able to overcome EGFR T790M and C797S resistance mutations were reported, ${ }^{31-44}$ but these compounds are equipotent or more active on EGFR ${ }^{\mathrm{wt}}$ (see R1-3 in Figure 2). ${ }^{31-38}$ Conversely, some cases of good selectivity for mutated versus wild-type EGFR have been reported but with low overall in vitro potency (see R4 and R6 in Figure 2). ${ }^{40-42}$ The noncovalent inhibitor $\mathbf{R 5}^{43}$ has demonstrated acceptable p-EGFR biomarker modulation in vivo in a NCI-H1975 xenograft model $\left(\right.$ EGFR $\left.^{\text {L858R T790M }}\right)$ after high oral dose administration, but the compound displays an insufficient EGFR wt-sparing ratio. Allosteric EGFR inhibitors, which overcome T790M and C797S resistance and display EGFR wt-sparing behavior, have been reported, ${ }^{45-49}$ but these compounds are only active on the L858R mutant but not on the most prevalent del19 mutant. 


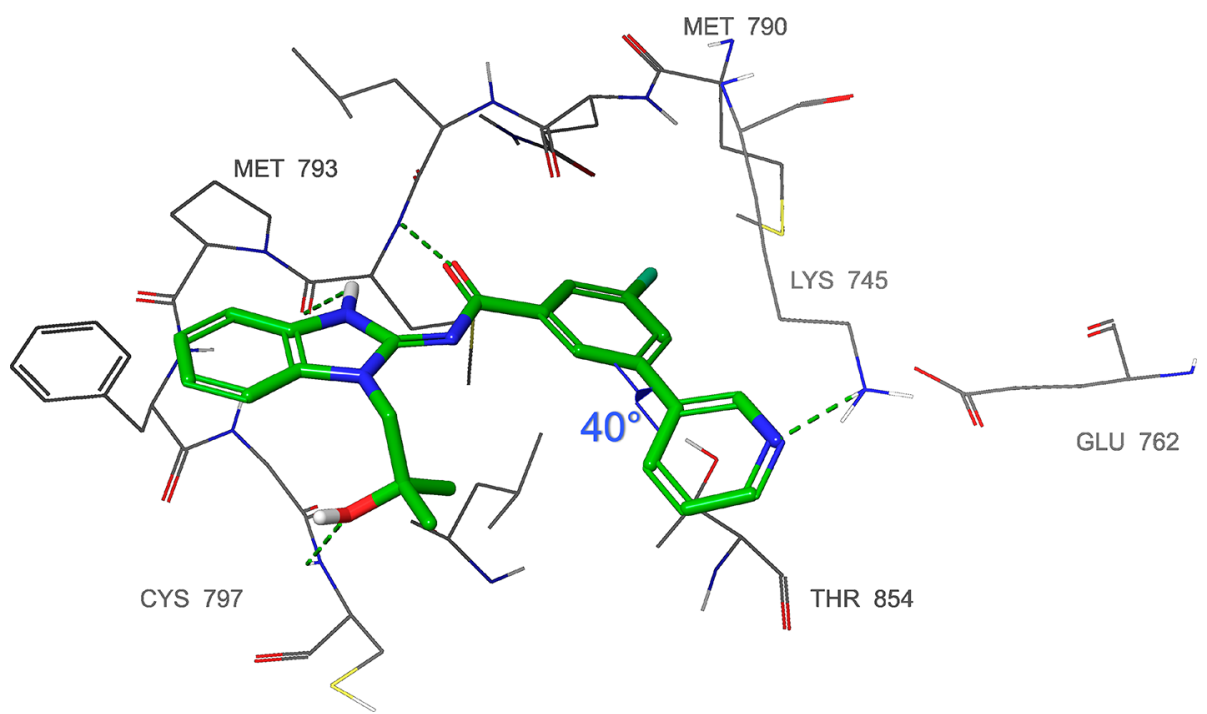

Figure 3. X-ray structure of ligand 1 (PDB: 6S9B) bound to the ATP pocket of the EGFR ${ }^{\mathrm{L} 858 \mathrm{R} \text { T790M }}$ protein.

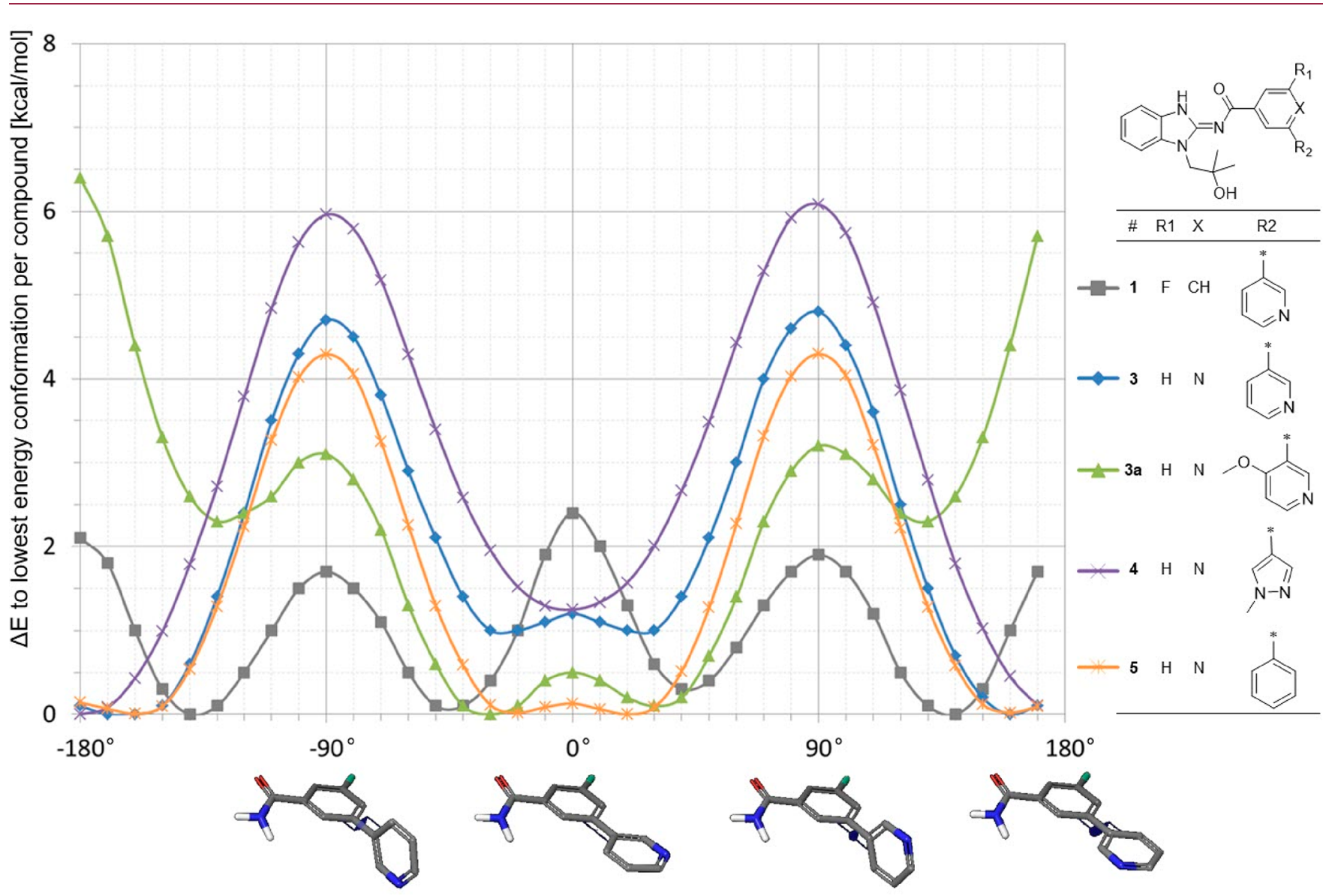

Figure 4. QM-torsion angle scans for compounds 1, 3, 3a, 4, and 5. The baseline energy is set for each compound individually (to zero), and not deducted from the lowest energy of all compounds.

In this Article, we describe the discovery of BI-4020, the first compound to exhibit a next generation EGFR TKI profile, wtsparing, capable of inhibiting complex EGFR mutations containing T790M and/or C797S modifications, including a triple cis mutation in the $\mathrm{EGFR}^{\text {del19 }}$ background. Key to the discovery was the identification of a highly selective but moderately potent benzimidazole by screening our corporate selective kinase inhibitor library followed by complete rigidification of the molecule through macrocyclization. BI4020 is a noncovalent, macrocyclic TKI, which inhibits not only the triple mutant EGFR ${ }^{\text {del19 T790M C797S }}$ variant but also the double mutant EGFR ${ }^{\text {del19 T790M }}$ and primary mutant EGFR ${ }^{\text {del19 }}$ while sparing activity against EGFR ${ }^{\mathrm{wt}}$ (see Figure 2 and Table 4). BI-4020 shows high potency on EGFR mutant cells, high kinome selectivity, and good DMPK properties, which led to 
tumor regressions in the human PC-9 (EGFR ${ }^{\text {del19 T790M C797S) }}$ triple mutant NSCLC xenograft model in mice.

\section{RESULTS AND DISCUSSION}

Selectivity First: Screening for a Highly Selective Rather than a Highly Active Starting Point. At the outset of the project, we decided to start a screening campaign to find chemical starting points, which provided selectivity for the mutated EGFR proteins over EGFR ${ }^{\mathrm{wt}}$ protein rather than a high activity. We hypothesized that it would be easier to improve upon the activity of an EGFR ${ }^{\mathrm{wt}}$ selective molecule than it would be to rationally design EGFR ${ }^{\text {wt }}$ selectivity of a potent but unselective inhibitor. A structure-based design approach to generate selectivity for the EGFR primary activation mutation L858R and del19 over EGFR ${ }^{\mathrm{wt}}$ was further ruled out as no structural differences between the binding pockets from the publicly available X-ray structures of the $\mathrm{EGFR}^{\mathrm{L} 858 \mathrm{R}}$ and EGFR ${ }^{\mathrm{wt}}$ proteins were observable.

Instead, we resolved to design a focused in-house library based on Boehringer Ingelheim kinase selectivity panel data obtained with previous research compounds from various projects. Focusing on selective kinase inhibitors where more than $10 \mathrm{mg}$ of solid was in stock and that fulfilled minimal drug-like properties (heavy atoms $\leq 34$ or soluble at $\mathrm{pH} 6.8$ ), we compiled a list of 1826 kinase inhibitors from 40 past kinase and 47 nonkinase projects. A compound, which qualifies as a selective kinase inhibitor, needs to be tested against at least 30 kinases and should be active in at least 2 assays (single concentration measurement using a biochemical kinase assay; compound needs to display a value below $50 \%$ of control), but should not hit more than $10 \%$ of all tested kinases. Interestingly, this Selective Kinase Inhibitor (SKIny) Screening Library covered 269 kinases.

Despite the fact that we were most interested in the more frequent appearing $\mathrm{EGFR}^{\text {del19 } 7790 \mathrm{M} \text { C797S }}$ mutation, the triple mutant EGFR ${ }^{\text {L858R T790M C979S }}$ protein was used for the biochemical screening assay, because we were not able to obtain sufficient high quality amounts of the $\mathrm{EGFR}^{\text {del19 T790M C797S }}$ protein. In parallel to an activity screening, we conducted a selectivity screening using the EGFR ${ }^{\text {wt }}$ protein to directly assess the WT-sparing effect of the hits found in the screen. The aminobenzimidazole $\mathbf{1}$ was identified as a promising hit from the screen as it showed reasonable affinity to mutated EGFR ( IC $_{50}$ EGFR $^{\text {L858R T790M C797S }}=2100$ $\mathrm{nM} ; \mathrm{IC}_{50} \mathrm{EGFR}^{\text {del19 T790MC7975 }}=250 \mathrm{nM}$ ) and had no measurable affinity to $\mathrm{EGFR}^{\mathrm{wt}}$ (see Table 1). To assess the overall kinase selectivity of $\mathbf{1}$, we performed a kinase selectivity assay $^{50}$ with 238 kinases and found that only 5\% of the screened kinases were inhibited above $70 \%$. To determine the overall kinase selectivity for further compounds more quickly, we have defined a diverse set of 30 kinases representing the kinome. For key compounds 1, 3, and BI-4020, we have confirmed the results of the small panel with a larger set of kinases (see Table 1 and 2). Gratifyingly, we were also already able to measure biomarker modulation in an

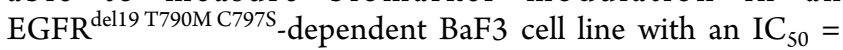
$790 \mathrm{nM}$.

$\mathrm{EGFR}^{\mathrm{L} 858 \mathrm{R}}$ protein was used for protein crystallography as $\mathrm{EGFR}^{\text {del19 }}$ protein has proven particularly recalcitrant to X-ray crystallography with no structures published. Compound $\mathbf{1}$ was successfully crystallized with EGFR $^{\mathrm{L} 858 \mathrm{R}}$ with the gatekeeper mutation T790M (Figure 3). From the X-ray structure, a twopoint hinge binding motive can be seen, with the benzimidazole $\mathrm{N}-\mathrm{H}$ and carbonyl group binding to Met793. The isobutyl hydroxy group fills the sugar pocket ${ }^{51}$ of the kinase, while the pyridine substituent in the $R_{2}$-position (nomenclature see Figure 4) binds to the Lys745 in the phosphate region of the pocket. No clash between the bulky Met790 gatekeeper residue and the benzimidazole is observed. Important for our further optimization was the observation that the torsion angle between the two aromatic rings of $\mathbf{1}$ is $\sim 40^{\circ}$, which was found to be a low-energy conformation based on a QM-torsion angle scan (see Figure 4). Therefore, the dihedral angle was scanned in $10^{\circ}$ steps while optimizing all other degrees of freedom within the ligand on the $\omega \mathrm{B} 97 \mathrm{XD} /$ cc-pVDZ level of theory. ${ }^{52}$

A close analogue (2) missing the fluorine atom in the $R_{1}$ position (see Table 1) was found to show similar activities in the biochemical and biomarker assays $\left(\mathrm{IC}_{50} \mathrm{EGFR}^{\mathrm{L} 858 \mathrm{R} \text { T790M C797S }}=2700 \mathrm{nM} ; \mathrm{IC}_{50}\right.$ EGFR $\left.^{\text {del19 T790M C797S }}=173 \mathrm{nM}\right)$. Because of synthetic accessibility, we decided to move on with our further optimization program without a substituent in the $R_{1}$ position.

In the next step, we decided to address the hydroxyl group of the side chain of Thr854 via a nitrogen acceptor from the Xposition of the central aromatic ring system (see Figure 4). In addition, the newly designed ligands should still have a torsion angle of $30-40^{\circ}$ at a low-energy conformation to enable a proper interaction with Lys754. To access both requirements, we performed a QM-torsion angle scan for the bis aryl system of the newly designed compounds 3, 3a, and 4 (Figure 4).

The pyridyl nitrogen of the $\mathrm{R}_{2}$ moiety of compound 3 desymmetrizes the bis aryl system further, and therefore a larger energy difference between the minima $\left(30^{\circ}\right.$ and $\left.160^{\circ}\right)$ in comparison to compound $\mathbf{1}$ is observed (see Figure 4). In case of the minimum at $30^{\circ}$, both pyridyl nitrogens of compound 3 are located at the same side, which leads to an unfavorable dipole-dipole interaction (overall dipole: $3.87 \mathrm{D}$ ) as compared to the minimum at $160^{\circ}$ for which the pyridyl nitrogens are located at the opposite side leading to partial dipole cancellation (overall dipole: $2.35 \mathrm{D}$ ).

The local minimum at $30^{\circ}$ of compound 3 would allow the ligand to interact via the pyridyl nitrogen of the $R_{2}$ moiety with Lys745. However, this local minimum is approximately $1 \mathrm{kcal} /$ mol higher than the absolute minimum, which is located at $160^{\circ}$. Therefore, an energy penalty has to be paid for the nonoptimal dihedral angle, but a gain in binding affinity was expected due to the interaction with Thr854. Interestingly, the benzimidazole 3 showed a factor of 3-8 improved activity in the biochemical assays $\left(\mathrm{IC}_{50} \mathrm{EGFR}^{\mathrm{L} 858 \mathrm{R} \text { T790M C797S }}=353 \mathrm{nM}\right.$; $\mathrm{IC}_{50} \mathrm{EGFR}^{\text {del19 T790M C797S }}=57 \mathrm{nM}$ ) and demonstrated an even more pronounced gain in potency in the cellular biomarker modulation assay, while at the same time maintaining the low affinity for wild-type EGFR.

For compound 4, a similar situation was observed. A local minimum was found at a torsion angle of $0^{\circ}$, while the absolute minimum is approximately $1 \mathrm{kcal} / \mathrm{mol}$ lower and is located at $180^{\circ}$. Again, an energy penalty must be paid for the nonoptimal dihedral angle, but on the other hand a gain in binding affinity could be expected due to the interaction with Thr854. Also, for compound 4, a slight improvement of activity was observed in biochemical and an even more pronounced gain in the cellular biomarker modulation assay.

We investigated several different aromatic ring systems for the $R_{2}$ position with the goal to identify motifs, which would bind with the absolute minimum conformation regarding the 


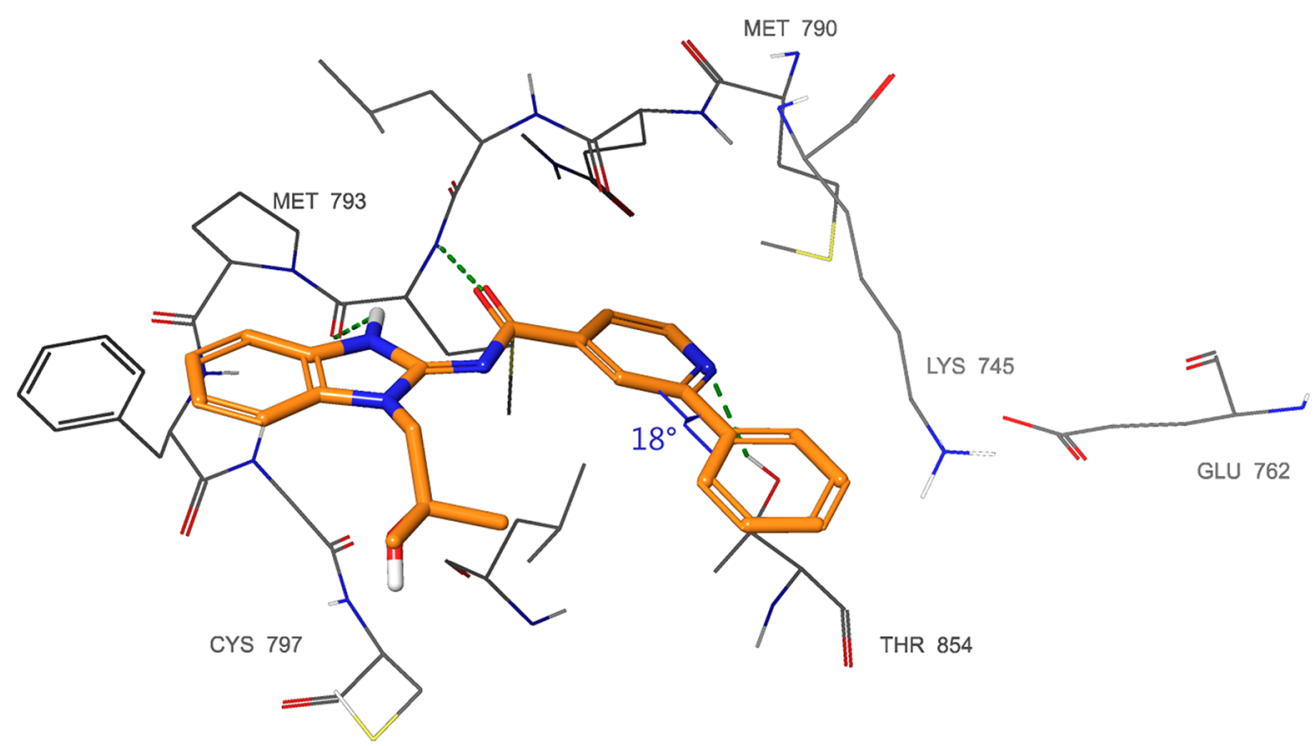

Figure 5. X-ray structure of compound 5 (PDB: 6S9C) in complex with $\mathrm{EGFR}^{\mathrm{L} 858 \mathrm{R} T 790 \mathrm{M}}$.

dihedral angle of the bis aryl system to EGFR. One possible solution is shown by compound 3a, which bears a 4-methoxypyrid-3-yl moiety at the $\mathrm{R}_{2}$ position. The QM-torsion angle scan (see Figure 4) for the bis aryl system showed high energy for dihedral angle $160-180^{\circ}$ due to unfavorable interactions of the methoxy group and the facing pyridyl nitrogen, but an absolute minimum at $30^{\circ}$. The unfavorable dipole-dipole interaction between the two ring nitrogen atoms at $30^{\circ}$ is also given for compound 3a, but the energy penalty is compensated by the favorable electrostatic interactions of the methoxy group with the facing proton (see Figure S1). Therefore, the energy at $30^{\circ}$ of ligand $3 \mathrm{a}$ is lower than that for compound 3 . This optimized binding conformation of ligand $3 \mathbf{a}$ translates into a 30 -fold improved biochemical activity based on the $\mathrm{EGFR}^{\mathrm{L} 858 \mathrm{R} \text { T790M C797S }}$ protein as compared to ligands 3 and 4. The same trend can be seen comparing the biochemical EGFR $^{\text {del19 T790M C797S }}$ data. This improved biochemical activity led to a 35-fold improved p-EGFR ${ }^{\text {del19 T790M C797S }}$ biomarker modulation and to a 5-fold improved antiproliferative effect in $\mathrm{BaF} 3$ cells as compared to ligands 3 and 4 . However, the compound displayed a clearly lower general kinase selectivity as compared to compounds 3 and 4 (36\% hits; see Table 1 ). These data show that activity can be massively gained by optimal interaction with Lys745, but at the expense of reduced kinase selectivity.

We hypothesized that better kinase selectivity could be achieved, if the pocket around Lys745 (phosphate region) is addressed by an aromatic system, which bears no acceptor. Prerequisite for this strategy was that the envisioned $\mathrm{R}_{2}$ moiety does not clash with Lys745, which could be achieved with a dihedral angle of $<20^{\circ}$.

To probe the hypothesis, we synthesized benzimidazole 5, which does not contain a hydrogen-bond acceptor atom in the second aromatic ring and carries only a symmetric phenyl ring in the $\mathrm{R}_{2}$-position. Therefore, almost no energy difference is seen between the minima $\left(20^{\circ}\right.$ and $160^{\circ}$; see Figure 4$)$. To our delight, we found that, while the biochemical and cellular potency against EGFR mutated cells was basically unchanged as compared to compound 3 , the selectivity was significantly improved, as it is evident from the not observable cytotoxic activity against EGFR independent cells. At the same time, the kinase selectivity was found to be very high, as only mutant EGFR was hit among a panel of 30 kinases. Furthermore, benzimidazole 5 also showed an excellent wt-sparing effect based on the comparison of the antiproliferative effect on EGFR $^{\text {del19 T790M C797S }}$ versus EGFR ${ }^{\text {wt }}$ in BaF3 cell lines (see Table 1).

The X-ray structure of compound 5 with EGFR ${ }^{\text {L858R T790M }}$ shows (see Figure 5) that the compound binds to the protein with the expected dihedral angle of the bis aryl system of approximately $20^{\circ}$. In addition, the distance to the Lys 745 and Glu762 is sufficiently large $(3.5 \AA)$ to avoid a clash.

Entropy-Driven Optimization: Rigidification through Macrocyclization. Compound 5 represented a selective but not yet sufficiently potent compound (Table 1, entry 6). In analogy to the discovery of lorlatinib, ${ }^{11}$ we chose reduction of ligand entropy through macrocyclization as the strategy to improve potency. ${ }^{53-55} \mathrm{We}$ pursued both theoretical and experimental methods to assist the design of cyclized compounds. Initially, as for the computational conformation analysis of ligand $\mathbf{5}$, the MOE module LowModeMD, ${ }^{56}$ followed by semi empirical (MOPAC, AM1) energy minimization of all of the conformers in vacuo, was employed for the analysis and selection of low-energy conformers. In the course of the project, we then complemented this approach with enhanced sampling molecular dynamics methods in explicit solvation. ${ }^{57}$ These findings were supported by a detailed 2D NMR analysis of compound 5, which showed ROE correlations between protons, as indicated in Scheme 1. The ROEs support the presence of both active and inactive conformational states in the population observed in solution. This was further corroborated by QM-DFT ${ }^{13} \mathrm{C},{ }^{1} \mathrm{H}$, and partial ${ }^{15} \mathrm{~N}$ chemical shift predictions, which support a Boltzmann-weighted energy distribution, with significant population of active and inactive conformers. ${ }^{57,58}$ We therefore expected a significant improvement of binding affinity to EGFR $^{\text {del19 T790M C979S }}$ if the molecule could be constrained in its "active" binding conformation.

Starting from ligand $\mathbf{5}$ as a template for the active conformation, several different macrocyclic variants with varying linker lengths and attachment points were designed. The macrocycles were then virtually subjected to conforma- 
Scheme 1. Two-Dimensional Representation of the Most Prevalent Conformations of Ligand 5 As Computationally Predicted and Detected in Solution by $2 \mathrm{D}-\mathrm{NMR}^{a}$
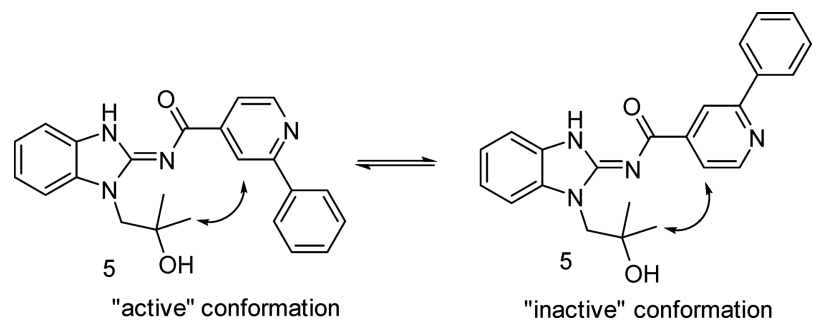

${ }^{a}$ Important ROE-correlations are displayed as arrows.

tional searches (MOE LowModeMD), ${ }^{56}$ followed by AM1 energy minimization of all conformers. Low-energy conformations were compared to the binding conformation of amino benzimidazole 5 and macrocyclic ligand 6, with a $\mathrm{C}_{5} \mathrm{H}_{10} \mathrm{O}$ linker found to display a good overlap with the desired "active" conformation (see Figure 6).

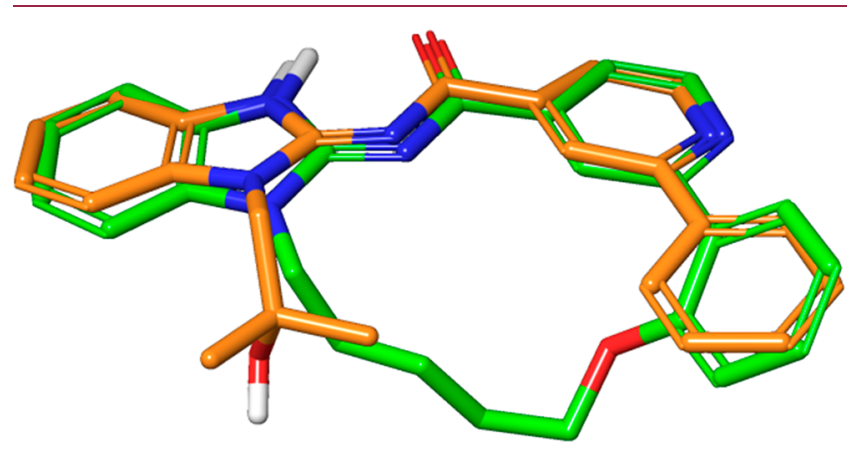

Figure 6. Overlay of X-ray-based structure of compound 5 (orange) and calculated minimum conformation structure of macrocyclic ligand 6 (green).

The first macrocyclic ligand 6 displayed a biochemical activity in the EGFR del19 T790M C797S assay at the assay wall, ${ }^{58}$ which hampers the evaluation of the activity improvement. Fortunately, the biochemical activity of macrocycle 6 in the $\mathrm{EGFR}^{\mathrm{L} 858 \mathrm{R} \text { T790M C797S }}$ assay is still above the assay wall (see Table S8, entry 1), and therefore a 17-fold improved biochemical activity over the open chain ligand 5 can be determined. The gain in biochemical activity translates into a 5 -fold improvement of cellular potency over the open chain ligand $\mathbf{5}$ as is evident from the inhibition of the p-EGFR signal and antiproliferative effect on EGFR ${ }^{\text {del19 T790M C979S }}$-dependent BaF3 cells (see Table 2, entry 1). Noteworthy for compound 6 was the favorable EGFR ${ }^{\text {wt }}$ and general kinase selectivity $(0 / 30$ kinases were hit at $1 \mu \mathrm{M})^{50}$ observed.

From the protein X-ray structure (see Figure 7), it is evident that the observed potency improvement resulted mostly from the conformational restrictions as no new or changed interactions with the EGFR protein are visible. Also, the observed binding conformation of ligand $\mathbf{6}$ is in excellent agreement with the computationally predicted minimum conformation.

From the predicted minimum energy conformation of ligand 6, it was expected that the bis aryl torsion angle in the macrocyclic ligand should be constrained to approx $\sim 40^{\circ}$, a value that is very close to the observed angle in the X-ray structure $\left(39^{\circ}\right)$ (see Figure 7 ). This indicated that a reinstallment of a hydrogen-bond acceptor in the second aromatic ring should lead to a favorable hydrogen-bond formation to Lys745. Therefore, we decided to further improve the potency of the molecule by implementing a polar interaction with Lys745, as was seen in ligands 1-4. We chose the $N$-methylpyrazole from ligand 4 rather than the pyridine moiety of compound 3 , because the metabolic stability predicted from human hepatocytes was superior for ligand 4 (\%QH: $12 \%)$ over ligand 3 (\%QH: $34 \%)$. Additionally, a fluorine atom was reinstalled in the $\alpha$-position $\left(\mathrm{R}_{1}\right)$ of the pyridine nitrogen to fill the observed small subpocket in the protein X-ray structure of 6 with the EGFR protein (see Figure 7). We hypothesized that this substituent might be in part responsible for the excellent general kinase selectivity of ligand 1 . These structural changes resulted in ligand 7, which showed at least an additional 5-fold improved biochemical activity in the EGFR ${ }^{\mathrm{L} 858 \mathrm{R} \text { T790M C797S }}$ assay. It is noteworthy that macrocycle 7 also shows activity around the assay wall in this biochemical assay (see Table S8, entry 2). This prevents the use of biochemical EGFR assays to determine further potency improvements. Also, a 5-fold improved antiproliferative effect against EGFR ${ }^{\text {del19 }}$ T790M C797S dependent cells of ligand 7 versus 6 can be seen. At the same time, we observed a submicromolar antiproliferative effect against EGFR ${ }^{\mathrm{wt}}$ and EGFR independent cells for the first time. However, the ratio of the $\mathrm{IC}_{50}$ values remained unchanged between ligand $6\left(\mathrm{IC}_{50} \mathrm{EGFR}^{\mathrm{wt}} / \mathrm{IC}_{50} \mathrm{EGFR}^{\text {del19 T790M C7975 }}=\right.$ 48) and ligand 7 ( IC $_{50} \mathrm{EGFR}^{\mathrm{wt}} / \mathrm{IC}_{50} \mathrm{EGFR}^{\text {del19 T790M C7975 }=}$ 45 ), suggesting a generally improved kinase activity instead of a specific improvement for mutant EGFR. The size of the substituent at the $\mathrm{R}_{1}$-position was increased from fluorine to methyl, which gave rise to compound 8 . While the cellular potency of aminobenzimidazole $8\left(\mathrm{IC}_{50} \mathrm{EGFR}^{\text {del19 } \mathrm{T} 790 \mathrm{M} \mathrm{C} 797 \mathrm{~S}}=\right.$ $5 \mathrm{nM}$ ) was found to be unchanged as compared to ligand 7 $\left(\mathrm{IC}_{50} \mathrm{EGFR}^{\text {del19 T790M C797S }}=6 \mathrm{nM}\right)$, the selectivity for EGFR mutant-dependent cells over EGFR ${ }^{\text {wt }}$-dependent cell or EGFR independent cells was significantly improved for ligand $8\left(\mathrm{IC}_{50}\right.$ $\left.\mathrm{EGFR}^{\mathrm{wt}} / \mathrm{IC}_{50} \mathrm{EGFR}^{\text {del19 T790M C797S }}=460\right)$. The enhanced selectivity for EGFR mutant-dependent cells over EGFR independent cells was also reflected by the improved overall kinase selectivity profile (see Table 2). For all further studies, we kept the methyl group in the $\mathrm{R}_{1}$-position as a "selectivity trigger", which allowed us to further improve the potency while maintaining excellent kinase selectivity.

In the next step, we reinvestigated the three-dimensional shape of our molecule by means of computational conformation analysis. From our previous computations and from the protein X-ray structures with ligand 6, we knew that the conformation of the macrocyclic ligands was not flat but rather bowl shaped. From the lack of a stereo center in ligands 6-8, these bowl-shaped molecules could adopt two enantiotopic minimum energy conformations (see Figure 8: green and magenta ligands). We hypothesized that the interconversion between these two enantiotopic conformers would go through a low-energy transition state and would be fast at room temperature. From the protein X-ray structures with ligand 6, the desired enantiomer was already known (see Figure 7 and Figure 8; green ligand), and we envisioned a further improvement of the cellular potency by an additional restriction of the ligand to only one enantiotopic minimum conformer. To do so, we decided to install a stereo center in the linker and therefore to desymmetrize the molecule, so that the conformation at the newly installed stereo center would 
Table 2. SAR for the Macrocyclic Benzimidazoles 6-9 and BI-4020 ${ }^{a}$

\begin{tabular}{|c|c|c|c|c|c|c|c|c|c|}
\hline & & & & & $\begin{array}{c}\text { BaF3 cells } \\
\text { biomarker }{ }^{\mathrm{c}}: \mathrm{IC}_{50}[\mathrm{nM}]\end{array}$ & anit-prol & $\begin{array}{l}\text { BaF3 cells } \\
\text { liferation }{ }^{d}: \mathrm{IC}_{5}\end{array}$ & $50[\mathrm{nM}]$ & $\begin{array}{l}\text { Kinase sel. } \\
\text { \%hit (\#total) }\end{array}$ \\
\hline \# & $\mathrm{R}_{1}$ & $\mathrm{Ar}$ & $\mathrm{R}_{2}$ & $\mathrm{R}_{3}$ & p-EGFR ${ }^{d 19}$ TM CS $^{*}$ & EGFR $^{\mathrm{d} 19 \mathrm{TMCS}^{*}}$ & EGFR $^{w t}$ & EGFR indep. & \\
\hline 6 & $\mathrm{H}$ & & $\mathrm{H}$ & $\mathrm{H}$ & $3.0(1.10)$ & $27(1.10)$ & $1,300(1.13)$ & $1,600(1.17)$ & $0 \%(30)$ \\
\hline 7 & $\mathrm{~F}$ & & $\mathrm{H}$ & $\mathrm{H}$ & $1.2(1.11)$ & $6.0(1.42)$ & $270(1.10)$ & $330(1.24)$ & $26 \%(30)$ \\
\hline 8 & $\mathrm{Me}$ & & $\mathrm{H}$ & $\mathrm{H}$ & $1.0(1.10)$ & $5.0(1.15)$ & $2,300(1.21)$ & $1,700(1.22)$ & $10 \%(30)$ \\
\hline 9 & $\mathrm{Me}$ & & $\mathrm{Me}$ & $\mathrm{H}$ & $0.8(1.14)$ & $1.0(1.25)$ & $1,100(1.10)$ & $1,000(1.23)$ & $13 \%(30)$ \\
\hline $\begin{array}{l}\mathrm{BI}- \\
4020\end{array}$ & $\mathrm{Me}$ & & $\mathrm{Me}$ & & $0.6(1.07)$ & $0.2(1.15)$ & $190(1.19)$ & $1,100(1.15)$ & $\begin{array}{c}7 \%(30) \\
8 \%(238) \\
7 \%(393)\end{array}$ \\
\hline
\end{tabular}

${ }^{a}$ Data are reported as geometric mean of at least three independent measurements, and in brackets is the geometric standard deviation as multiplicative factor given. *: EGFR ${ }^{\mathrm{d} 19} \mathrm{TM}$ CS means EGFR del19 T790M C7975. ${ }^{b}$ Kinase selectivity was determined using the "SelectScreen Kinase Profiling Services" from ThermoFisher. " ${ }^{c}$ Measurement of inhibition of the p-EGFR del19 T790M C797S signal in BaF3 cells after $4 \mathrm{~h}$ compound treatment. ${ }^{d} \mathrm{BaF} 3$ cells bearing EGFR ${ }^{\text {del19 }}{ }^{\mathrm{T} 790 \mathrm{M} \mathrm{C} 797 \mathrm{~S}}$ protein were treated for 3 days with compound, and the effect on proliferation was measured.

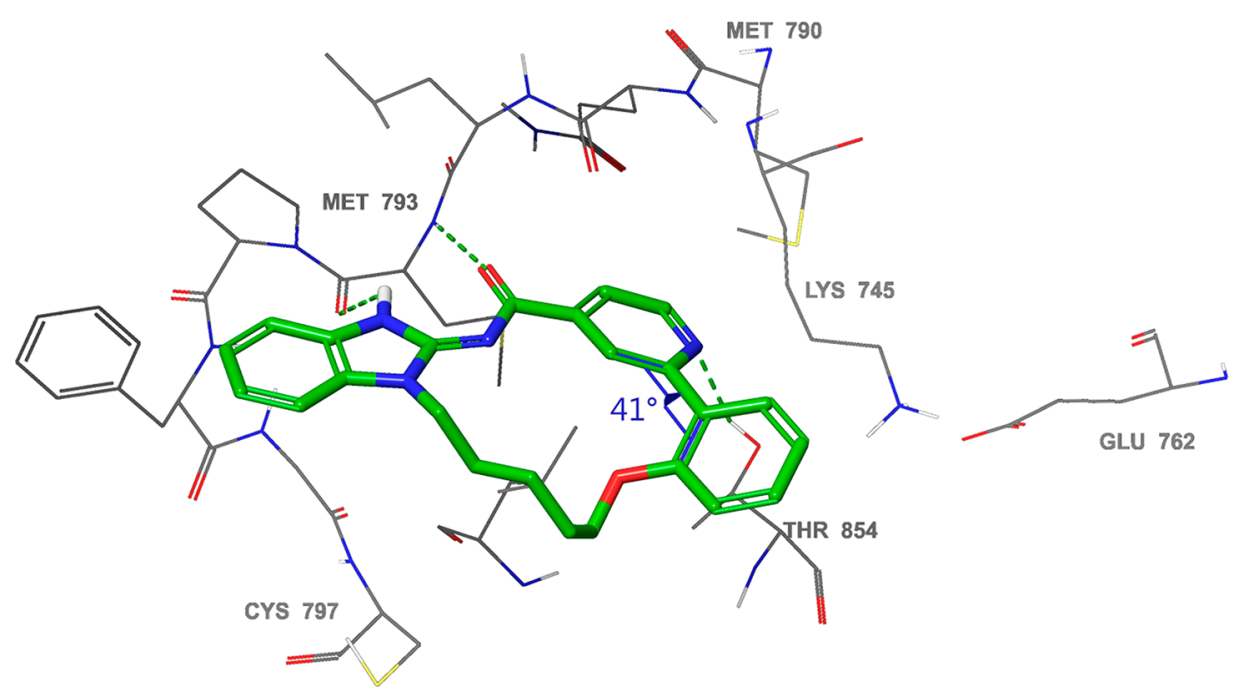

Figure 7. X-ray structure of compound 6 (PDB: 6S9D) in complex with EGFR ${ }^{\mathrm{L} 85 \mathrm{R} \text { T790M }}$.

determine the conformational outcome of the entire ligand. Furthermore, we speculated that a correctly placed alkyl substituent in the linker would help to fill the "sugar-pocket" of the EGFR protein, which was previously filled by the bulky isobutyl-hydroxy group in ligands $\mathbf{1 - 5}$.

Again, we compared the calculated minimum conformations of the newly designed ligands to the desired "active" conformation of ligand 6 , this time focusing our attention toward the optimal conformation of the linker and the absolute configuration of the minimum conformers. After investigating numerous possible macrocyclic ligands, we decided to synthesize ligand 9 with an additional methyl group in 2position of the linker. On the basis of our calculations, the newly installed stereogenic center needed to be $(R)$-configured to give the ligand in the desired shape. Satisfyingly, we found that ligand 9 shows an additional improvement in cellular 


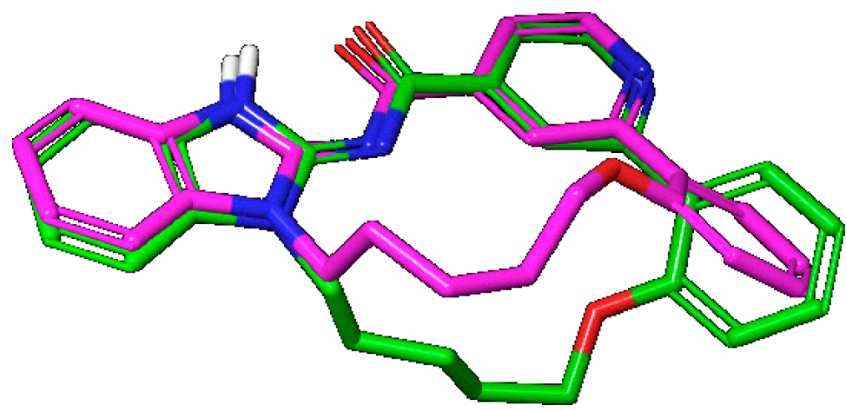

Figure 8. Two calculated enantiotopic minimum energy conformations of compound 6 .

potency against mutant EGFR-dependent cells ( $\mathrm{IC}_{50}$ $\mathrm{EGFR}^{\text {del19 T790M C979S }}=1 \mathrm{nM}$ ) without losing the favorable selectivity window against EGFR ${ }^{\mathrm{wt}}$-dependent cell lines $\left(\mathrm{IC}_{50}\right.$

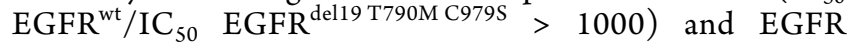
independent cell lines, and as before the overall kinase selectivity was maintained. While we were unsuccessful in obtaining an X-ray crystal structure of this molecule with the EGFR protein, we were able to solve a small-molecule X-ray structure of a very close analogue of 9 bearing a bromine substituent at the $\mathrm{R}_{3}$ position $9-\mathrm{Br}$ (see Figure 9).

The small-molecule X-ray structure of $9 \mathrm{Br}$ with the heavy atom in 6-position of the benzimidazole allowed not only for the unambiguous determination of the absolute configuration at the newly created stereo center ( $R$-configuration), but also confirmed the predicted minimum energy conformation of 9 (see Figure 9).

At this point in the project, we felt that no further optimization of the cellular potency of the benzimidazole ligands was necessary. Instead, we focused any further optimization toward improving the DMPK parameters of the molecules. Particularly, the high plasma protein binding and the low aqueous solubility of ligand 9 were of concern (see Table 3). We believed that the high lipophilicity at the phenyl core caused the observed low solubility. Therefore, we decided to investigate several different solubilizing groups attached to the phenyl core. From the X-ray structure of ligand 6 (see Figure 7) with the EGFR protein, an exit vector toward the solvent from positions 5 and 6 of the benzimidazole core became apparent.

During our studies, we found that only very few substituents at the 5-position were accepted without dramatic loss in cellular activity (data not shown). Therefore, we decided to focus on solubilizing groups at the 6-position of the molecule and synthesized several ligands with varying solubilizing groups. From this collection of molecules, ligand BI-4020 was identified as the most promising ligand with optimally balanced properties. The human clearance predicted by hepatocytes of compound BI-4020 was higher than that for ligand 9, but still in an acceptable range. Solubility, fraction unbound in plasma, and permeability of ligand BI-4020 were clearly improved as compared to ligand $\mathbf{9}$.

Surprisingly, an additional boost in cellular activity was observed with ligand BI-4020 $\left(\mathrm{IC}_{50} \mathrm{EGFR}^{\text {del19 T790M C979S }}=0.2\right.$ $\mathrm{nM}$ ) showing for the first time subnanomolar activity. Pampa data indicate that the cellular potency gain could be explained by the improved permeability of BI-4020 (Papp A-B at $\mathrm{pH}$ 7.4:5.3 $\times 10^{-6} \mathrm{~cm} / \mathrm{s}$ ) as compared to ligand 9 (Papp A-B at $\mathrm{pH}$ 7.4:0.2 $\left.\times 10^{-6} \mathrm{~cm} / \mathrm{s}\right)$. While the absolute activity on EGFR ${ }^{\mathrm{wt}}$ was also significantly increased $\left(\mathrm{IC}_{50} \mathrm{EGFR}^{\mathrm{wt}}=190 \mathrm{nM}\right)$, the ratio between $\mathrm{EGFR}^{\mathrm{wt}}$ and EGFR mutant-dependent cells remained high $\left(\mathrm{IC}_{50} \mathrm{EGFR}^{\mathrm{wt}} / \mathrm{IC}_{50} \mathrm{EGFR}^{\text {del19 T790M C979S }>}\right.$ 950). Furthermore, the ratio between EGFR independent and EGFR mutant-dependent cells was even increased. The kinase selectivity, now measured on three different panels (30 kinases, 238 kinases, and 394 kinases), remained also unchanged.

Aqueous solubility was determined from $1 \mathrm{mg} / \mathrm{mL}$ solid compound dispensed into aqueous McIlvaine buffer $(\mathrm{pH} 4.5$ or 6.8), or dissolved in acetonitrile/water (1:1) as reference. Dissolved concentrations were determined with an Agilent $1200 \mathrm{HPLC} / \mathrm{DAD}-\mathrm{UV}$ system.

Plasma protein binding (PPB) was determined by equilibrium dialysis. Plasma was spiked with EGFR TKI and dialyzed against Soerensen buffer ( $\mathrm{pH} 7.4$ ) for $3 \mathrm{~h}$ at $37{ }^{\circ} \mathrm{C}$. PPB was calculated by quantifying EGFR TKI concentrations in plasma and buffer by HPLC/MS-MS. In vivo hepatic clearance (CL) was predicted by in vitro incubations of EGFR TKI with cryopreserved hepatocytes (Celsis IVT) and measured depletion over $240 \mathrm{~min}$ by quantitation of EGFR TKI by LC/MS/MS and using the well-stirred model. PAMPA parameters were determined as described previously. ${ }^{65}$

Next, we benchmarked the antiproliferative effects of BI4020 with osimertinib in a series of relevant EGFR mutant cell lines (see Table 4).

While the covalent inhibitor osimertinib showed only weak in vitro biomarker modulation of the triple mutant EGFR due to the Cys797 to Ser797 resistance mutation, noncovalent inhibitor BI-4020 showed strong subnanomolar potency (see Table 4). The strong biomarker modulation of ligand BI-4020 translates into subnanomolar antiproliferative effects against EGFR $^{\text {del19 T790M C979S }}$-dependent BaF3 cells, whereas osimertinib was approximately 4000-fold less active. Osimertinib and BI-4020 display equivalent activity on $\mathrm{EGFR}^{\text {del19 }} \mathrm{BaF} 3$ cells as well as comparable selectivity for EGFR mutant over EGFR ${ }^{\text {wt }}$ (see Table 4). As expected already from the BaF3 cell profile,<smiles>CCCOc1c(-c2cc(C(=O)N=c3[nH]c4ccc(Br)cc4n3CC(C)C)cc(C)n2)cnn1C</smiles>

$9 \mathrm{Br}$

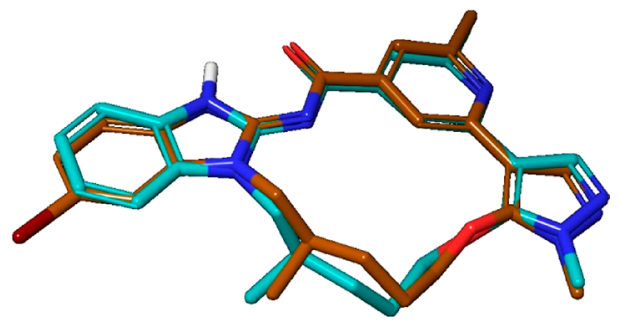

Figure 9. Structure of $\mathbf{9 B r}$ and comparison of small compound X-ray structure of $\mathbf{9 B r}$ (brown, CCDC 1941612) with the calculated minimum energy conformation of 9 (cyan). 
Table 3. DMPK Properties of Macrocycle 9 and BI-4020 in Comparison to Osimertinib

\begin{tabular}{|c|c|c|c|c|c|c|}
\hline \multirow[b]{2}{*}{ no. } & \multirow[b]{2}{*}{ solubility $^{a}$ at $\mathrm{pH} 6.8[\mu \mathrm{g} / \mathrm{mL}]$} & \multicolumn{2}{|c|}{$\begin{array}{c}\text { metabolic stability } \\
\text { hepatocytes }{ }^{b}[\% \mathrm{QH}]\end{array}$} & \multicolumn{2}{|c|}{ PPB free fraction ${ }^{c}$} & \multirow{2}{*}{$\frac{\text { permeability pampa assay }^{d}}{\text { Papp A-B }[\mathrm{cm} / \mathrm{s}] \text { at } \mathrm{pH} 7.4}$} \\
\hline & & mouse & human & mouse & human & \\
\hline 9 & $<0.1$ & 47 & 12 & $<0.3$ & 0.5 & $0.2 \times 10^{-6}$ \\
\hline BI-4020 & 95 & 56 & 47 & 1.2 & 7.5 & $5.3 \times 10^{-6}$ \\
\hline osimertinib & 86 & 83 & 27 & $<0.1$ & 2.5 & $2.7 \times 10^{-6}$ \\
\hline
\end{tabular}

${ }^{a}$ Aqueous solubility was determined from $1 \mathrm{mg} / \mathrm{mL}$ solid compound dispensed into aqueous Mcllvaine buffer ( $\mathrm{pH} 6.8$ ). ${ }^{b}$ In vivo hepatic clearance (CL) was predicted by in vitro incubations of $1 \mu \mathrm{M}$ EGFR TKI with cryopreserved hepatocytes (Celsis IVT) and measured depletion over 240 min by quantitation of EGFR TKI by LC/MS/MS. ${ }^{c}$ Plasma protein binding (PPB) was determined by equilibrium dialysis. Plasma was spiked with EGFR TKI and dialyzed against Soerensen buffer ( $\mathrm{pH}$ 7.4) for $3 \mathrm{~h}$ at $37^{\circ} \mathrm{C}$. ${ }^{d}$ Permeability was accessed by using a chamber separated by a microfilter disc (coated with structured layers of immobilized artificial phospholipid membranes) into a donor and an acceptor area.

Table 4. Comparison between Ligand BI-4020 and Osimertinib $^{a}$

\begin{tabular}{|c|c|c|c|}
\hline cellular potency $^{b}$ & unit & BI-4020 & osimertinib \\
\hline $\begin{array}{r}\text { IC }_{50} \text { p-EGFR BaF3 } \\
\left(\text { EGFR }^{\text {del19TMCSc }}\right)\end{array}$ & {$[\mathrm{nM}]$} & $0.6(1.07)$ & $3100(1.22)$ \\
\hline $\mathrm{IC}_{50} \mathrm{BaF} 3\left(\mathrm{EGFR}^{\text {del19TMCSc}}\right)$ & {$[\mathrm{nM}]$} & $0.2(1.15)$ & $780(1.06)$ \\
\hline $\mathrm{IC}_{50} \mathrm{BaF} 3\left(\mathrm{EGFR}^{\text {del19}}\right)$ & {$[\mathrm{nM}]$} & $1(1.09)$ & $1(1.11)$ \\
\hline $\mathrm{IC}_{50} \mathrm{BaF} 3\left(\mathrm{EGFR}^{\mathrm{wt}}\right)$ & {$[\mathrm{nM}]$} & $190(1.19)$ & $81(1.16)$ \\
\hline $\mathrm{IC}_{50} \mathrm{BaF} 3$ (EGFR indep.) & {$[\mathrm{nM}]$} & $1100(1.15)$ & $1100(1.23)$ \\
\hline $\mathrm{IC}_{50}$ PC-9 $\left(\mathrm{EGFR}^{\text {del19TMCS } c}\right)$ & {$[\mathrm{nM}]$} & $1.3(1.10)$ & $>1000$ \\
\hline $\mathrm{IC}_{50} \mathrm{~A} 431\left(\mathrm{EGFR}^{\mathrm{wt}}\right)$ & {$[\mathrm{nM}]$} & $200(1.12)$ & $84(1.05)$ \\
\hline kinase selectivity & $\begin{array}{l}\% \text { hit } \\
\text { (no. total) }\end{array}$ & $8 \%(238)$ & $7 \%(238)$ \\
\hline
\end{tabular}

${ }^{a}$ Data are reported as geometric mean of at least three independent measurements, and in brackets is given the geometric standard deviation as multiplicative factor. ${ }^{b} \mathrm{BaF} 3$ cells bearing different EGFR variants were treated for 3 days with compound, and the effect on proliferation was measured. ${ }^{c}$ EGFRdel19 TMCS means EGFR del19 T790M C797s.

also an excellent potency of $1.3 \mathrm{nM}$ was observed for BI-4020 in the NSCLC cell line PC-9 del19 T790M C797S, whereas osimertinib shows no anti proliferative effect up to $1 \mu \mathrm{M}$. The great EGFR wt-sparing effect of BI-4020 (150 fold; see Table 4) could be also demonstrated using the NSCLC cell pair A431 (EGFR ${ }^{\mathrm{wt}}$ ) and PC-9 del19 T790M C797S.

In Vitro and In Vivo Characterization of Macrocycle BI-4020: First EGFR TKI Showing Regression in an EGFR $^{\text {del19 T790M C797S }}$ Model. On the basis of the high potency and favorable in vitro DMPK parameters (see Table 3 and Table 4), the macrocycle BI-4020 was chosen for in vivo studies. The measured clearance of $56 \% \mathrm{QH}$ nicely matches the predicted clearance from hepatocytes. A volume of distribution of $4.2 \mathrm{l} / \mathrm{kg}$ indicates good distribution into tissue. After oral dosing of $10 \mathrm{mg} / \mathrm{kg}$, a medium bioavailability is observed, and the unbound $\mathrm{IC}_{50}$ is covered for more than $6 \mathrm{~h}$, enabling further biomarker studies (see Figure S4).

To test the ability of the macrocycle BI-4020 to inhibit EGFR in vivo, mice bearing subcutaneous PC-9 del19 T790M C797S xenotransplants were treated orally with the vehicle (natrosol) or $10 \mathrm{mg} / \mathrm{kg}$ of compound BI-4020. Tumors were subsequently harvested 6,18 , and $24 \mathrm{~h}$ after treatment with BI-4020. Analysis and quantification of Tyr1068 phosphorylated EGFR (p-EGFR) from tumor lysates revealed that single oral administration of $10 \mathrm{mg} / \mathrm{kg}$ of BI-4020 suppressed EGFR $^{\text {del19 T790M C797S }}$ phosphorylation 5-10-fold at all three time points as compared to the $6 \mathrm{~h}$ vehicle control (see Figure 10). These results demonstrate pharmacodynamic biomarker modulation of double resistance mutation-positive EGFR in

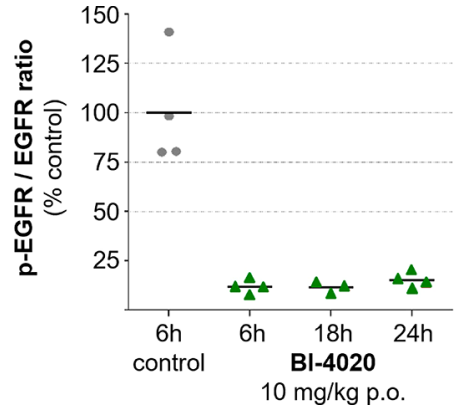

Figure 10. In vivo biomarker modulation by macrocycle BI-4020; $x$ axis, time point of biomarker analysis after treatment with vehicle (control) or with $10 \mathrm{mg} / \mathrm{kg}$ BI-4020 p.o.; $y$-axis, ratio of p-EGFR signal versus EGFR total signal.

vivo by oral administration of compound BI-4020 across a 24 $\mathrm{h}$ period and prompted us to conduct tumor growth efficacy experiments.

Daily oral treatment with $10 \mathrm{mg} / \mathrm{kg} \mathrm{BI-4020}$ was tested for in vivo efficacy in the EGFR del19 T790M C797S mutant human nonsmall cell lung cancer model PC-9del19T790MC797S. At treatment start, the tumors display a size between 53 and $153 \mathrm{~mm}^{3}$. All groups were treated for 19 days. BI-4020 induced strong regressions in 10 out of 10 tumors leading to a TGI of $121 \%(P=0.0005)$ (see Figure 11$)$, while daily treatment with $25 \mathrm{mg} / \mathrm{kg}$ osimertinib showed no effect of tumor growth with a TGI of $6 \%$ in the same model $(p>0.05)$. Both treatments were well tolerated in all mice.

\section{SYNTHESIS}

Schemes 2-7 illustrate the routes that were used to synthesize the compounds described herein.

Carboxylic acids $\mathbf{1 3 a}-\mathbf{f}$ were synthesized applying a Suzuki reaction of the commercially available bromides $11 \mathbf{a}-\mathbf{d}$ and boronic acids $12 \mathbf{a}-\mathbf{d}$ followed by an ester cleavage. Amide coupling of aminobenzimidazole 14 and carboxylic acids 13af led to the final compounds $\mathbf{1 - 5}$ (see Scheme 2).

Key intermediates $\mathbf{2 2 a - c}$ were synthesized from starting material $\mathbf{1 5}$ applying an alkylation reaction followed by the reduction of the nitro group in intermediate 17 and a ring closure reaction of diamine 18. Alternatively, key intermediates $22 \mathrm{a}-\mathrm{c}$ were synthesized by alkylating phenols $16 \mathrm{~b}, \mathrm{c}$ with 1,5 dibromo-pentane 19 followed by a substitution reaction of 20a,b with aminobenzimidazole 21 . Final compounds 6 , 7, and $9 \mathrm{Br}$ were synthesized from $22 \mathrm{a}-\mathrm{c}$ by cleaving the ester followed by an amide coupling. Key intermediate 26 was synthesized from aminobenzimidazole $\mathbf{2 1}$ applying an alkylation reaction with bromide $\mathbf{2 3}$ followed by an amide 

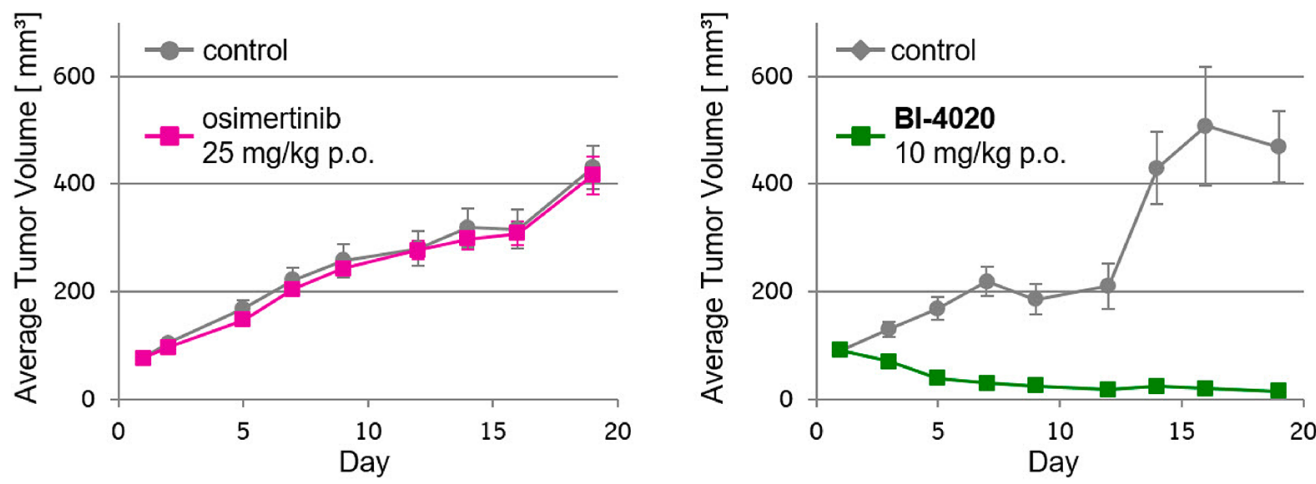

\begin{tabular}{|c|c|c|c|c|c|}
\hline & $\begin{array}{c}\text { Dose p.o. } \\
\text { [mg/kg] }\end{array}$ & Schedule & $\begin{array}{c}\text { TGI @ d d } \\
{[\%]}\end{array}$ & $p_{\text {Value }}$ & $\begin{array}{c}\text { Mortality } \\
{[x / 10]}\end{array}$ \\
\hline control & - & qd & - & * & 0 \\
\hline osimertinib & 25 & qd & 6 & $>0.05$ & 0 \\
\hline Bl-4020 & 10 & $q d$ & 121 & 0.0005 & 0 \\
\hline
\end{tabular}

Figure 11. Xenograft model with PC-9 cells bearing a EGFR ${ }^{\text {del19 } 7790 M \text { C797s }}$ protein; control group, 10 animals; treatment groups, 8 animals; animal type and strain, 6-8 week old, female BomTac:NMRI-Foxn $1^{\text {nu }}$ mice.

Scheme 2. Synthesis of Compounds $1-5^{a}$

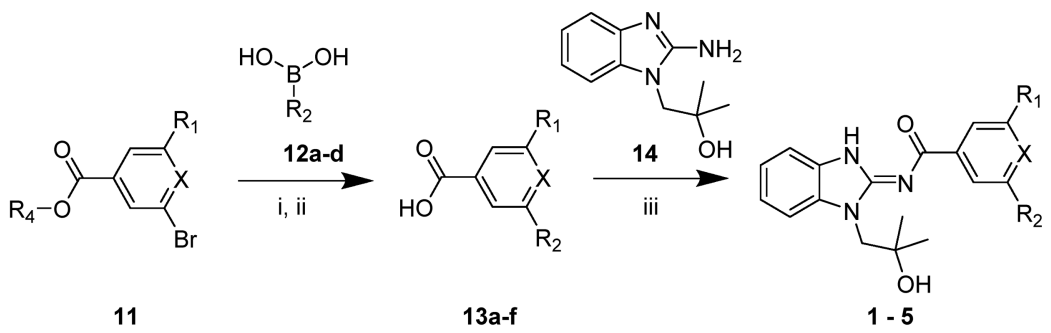

11a: $R_{1}=F ; R_{4}=H ; \quad X=C H ; \quad 12 a: R_{2}=$ pyridine-3-yl

13a: $\mathrm{R}_{1}=\mathrm{F} ; \mathrm{X}=\mathrm{CH} ; \mathrm{R}_{2}=$ pyridine-3-yl

11b: $R_{1}=H ; R_{4}=M e ; X=C H ; 12 b: R_{2}=4-M e t h o x y-p y r i d i n e-3-y l \quad 13 b: R_{1}=H ; X=C H ; R_{2}=$ pyridine-3-yl

11c: $R_{1}=H ; R_{4}=t B u ; X=N ; \quad 12 c: R_{2}=1-$ Methyl-1H-pyrazol-4-yl 13c: $R_{1}=H ; X=N ; \quad R_{2}=$ pyridine-3-yl

11d: $R_{1}=H ; R_{4}=M e ; X=N ; \quad 12 d: R_{2}=$ phenyl

13d: $R_{1}=H ; X=N ; \quad R_{2}=4-$ Methoxy-pyridine-3-yl

13e: $R_{1}=H ; X=N ; \quad R_{2}=1-$ Methyl-1H-pyrazol-4-yl

13f: $R_{1}=H ; X=N ; \quad R_{2}=$ phenyl

${ }^{a}$ Reagents and conditions: (i) Pd dppf, $\mathrm{Cs}_{2} \mathrm{CO}_{3}$, DME, water, $90{ }^{\circ} \mathrm{C}$; $16 \mathrm{~h}$; (ii) LiOH, THF, MeOH, $20{ }^{\circ} \mathrm{C}, 2 \mathrm{~h}$; (iii) HATU, DIPEA, dioxane, 60 ${ }^{\circ} \mathrm{C}, 12 \mathrm{~h}$.

coupling with carboxylic acid 25. Final compound 8 was synthesized via a Mitsunobu reaction starting from intermediate 26 (see Scheme 3).

Catalytic hydrogenation of $9 \mathbf{B r}$ with palladium on carbon led to macrocycle 9. Benzimidazol BI-4020 was synthesized from key intermediate $\mathbf{9 B r}$ applying a reductive carbonylation reaction, which led to aldehyde 27 , followed by a reductive amination reaction (see Scheme 4.)

Phenols 16a and $16 \mathrm{~b}$ were synthesized via a palladiumcatalyzed cross-coupling reaction from chloropyridines $\mathbf{2 8}$ and 30. Biaryl 36 was synthesized via Suzuki coupling of iodide 35 with boronic ester 34, which was prepared by a $\mathrm{CH}$ activation of pyridine derivate 32. Deprotection of phenolether 36 applying a palladium-catalyzed debenzylation reaction led to phenol 16c (see Scheme 5).

Key intermediate $\mathbf{2 5}$ was synthesized from 2-chloroisonicotinic acid methyl ester $\mathbf{3 8}$ applying a $\mathrm{CH}$ activation reaction followed by a Suzuki coupling and ester cleavage. SEM protection of pyrazole $\mathbf{2 9}$ was followed by an electro- philic aromatic substitution reaction leading to iodo-pyrazole 44 (see Scheme 6).

Nucleophilic aromatic substitution reaction of amine 43 with electrophile $\mathbf{4 1}$ followed by an esterification with methanesulfonyl chloride led to nitroaniline $\mathbf{1 5}$ (see Scheme 7).

\section{CONCLUSION}

The highly selective aminobenzimidazole 1 with $250 \mathrm{nM}$ inhibition constant for EGFR ${ }^{\text {del19 T790M C797S }}$ was identified by screening our corporate selective kinase inhibitor library. Structure-based design and macrocyclization led to the discovery of BI-4020, a highly active, noncovalent EGFR inhibitor. The strategy to increase the potency of a given ligand by restricting its conformational space to the "active" conformation by means of macrocyclization was shown to be a key contributor to success. BI-4020 displays a single digitnanomolar antiproliferative activity against EGFR mutantdependent cells, including cells that are dependent on EGFR bearing the two most clinically prevalent resistance mutations 
Scheme 3. Synthesis of Compounds $6-9 \mathrm{Br}^{a}$

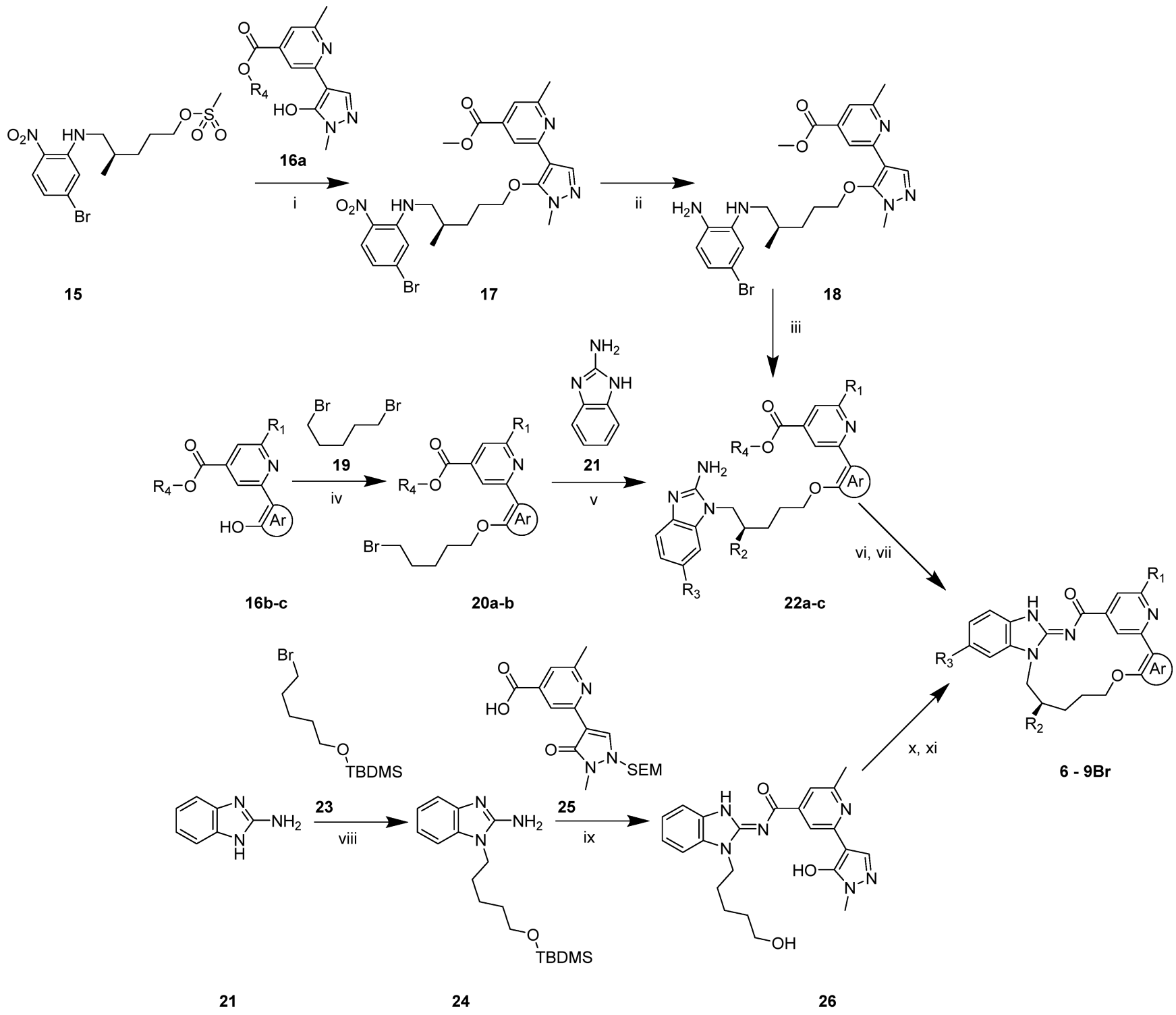

$\begin{array}{ll}\text { 16a: } & R_{1}=M e ; A r=\text { methylpyrazol; } R_{4}=M e ; \\ \text { 16b: } R_{1}=H ; A r=\text { phenyl; } \quad R_{4}=t B u\end{array}$

16b: $\mathrm{R}_{1}=\mathrm{H} ; \quad \mathrm{Ar}=$ phenyl; $\quad \mathrm{R}_{4}=\mathrm{tBu}$;

20a: $R_{1}=H ; A r=$ phenyl; $\quad R_{4}=t B u ; \quad 22 a: R_{1}=M e ; R_{2}=M e ; A r=$ methylpyrazol; $R_{3}=B r ; R_{4}=M e$;

20b: $R_{1}=F ; A r=$ methylpyrazol; $R_{4}=M e ;$

22a': $R_{1}=M e ; R_{2}=M e ; A r=$ methylpyrazol; $R_{3}=B r ; R_{4}=H$;

22b: $\mathrm{R}_{1}=\mathrm{H} ; \quad \mathrm{R}_{2}=\mathrm{H} ; \quad \mathrm{Ar}=$ phenyl; $\quad \mathrm{R}_{3}=\mathrm{H} ; \mathrm{R}_{4}=\mathrm{tBu}$

22c: $R_{1}=F ; \quad R_{2}=H ; \quad A r=$ methylpyrazol; $R_{3}=H ; R_{4}=H$;

${ }^{a}$ Reagents and conditions: (i) DMF, $\mathrm{K}_{2} \mathrm{CO}_{3}, 60^{\circ} \mathrm{C}, 16 \mathrm{~h}$; (ii) Pt and V/C, 3 bar $\mathrm{H}_{2}, \mathrm{MeOH}, 20^{\circ} \mathrm{C}, 16 \mathrm{~h}$; (iii) $\mathrm{CN}-\mathrm{Br} \mathrm{CH}_{2} \mathrm{Cl}_{2}, t-\mathrm{BuOH}, 20^{\circ} \mathrm{C}, 18$ h; (iv) $\mathrm{ACN}, \mathrm{K}_{2} \mathrm{CO}_{3}$, reflux, $16 \mathrm{~h}$; (v) $\mathrm{ACN}, \mathrm{K}_{2} \mathrm{CO}_{3}, 110^{\circ} \mathrm{C}(\mathrm{MW}), 16 \mathrm{~h}$; (vi) NaOH, THF, water, $20^{\circ} \mathrm{C}, 1 \mathrm{~h}$; (vii) $\mathrm{TBTU}^{\circ} \mathrm{NEt}_{3}, \mathrm{CH}_{2} \mathrm{Cl}_{2}, 20^{\circ} \mathrm{C}$, $30 \mathrm{~min}$; (viii) $\mathrm{ACN}, \mathrm{K}_{2} \mathrm{CO}_{3}$, reflux, $16 \mathrm{~h}$; (ix) $\mathrm{HATU}$, EtNi- $\mathrm{Pr}_{2}$, dioxane, $20^{\circ} \mathrm{C}, 16 \mathrm{~h}$; (x) $\mathrm{HCl}$ in dioxane, $\mathrm{EtOH}, 20^{\circ} \mathrm{C}, 16 \mathrm{~h}$; $(\mathrm{xi}) \mathrm{PPh}_{3}, \mathrm{DIAD}$, THF, $20{ }^{\circ} \mathrm{C}, 30 \mathrm{~min}$.

T790M and C797S. At the same time, BI-4020 shows a sufficient EGFR ${ }^{\text {wt }}$ sparing window and high kinome selectivity that is comparable to that observed with osimertinib. Furthermore, BI-4020 induces tumor regressions in the osimertinib resistant PC-9 $\left(\right.$ EGFR $\left.^{\text {del19 T790M C797S }}\right)$ triple mutant mouse xenograft model.

Altogether, for the first time, a highly active, EGFR ${ }^{\mathrm{wt}}$ sparing next generation EGFR TKI with an excellent in vitro and in vivo activity was presented. Representatives from this promising compound class will be further profiled to be developed toward a clinical candidate, which will be active in a clinical setting where osimertinib resistance has occurred and no targeted treatment option with a TKI is available at the moment.

\section{EXPERIMENTAL SECTION}

General Remarks. Chemicals and reagents were obtained from commercial suppliers and were used without further purification. All moisture-sensitive reactions were carried out under a nitrogen atmosphere in commercially available anhydrous solvents. Starting materials and intermediates are commercially available unless specified otherwise. NMR experiments were acquired as described in the Supporting Information. 
Scheme 4. Synthesis of Compounds 9 and BI-4020 ${ }^{a}$<smiles></smiles>

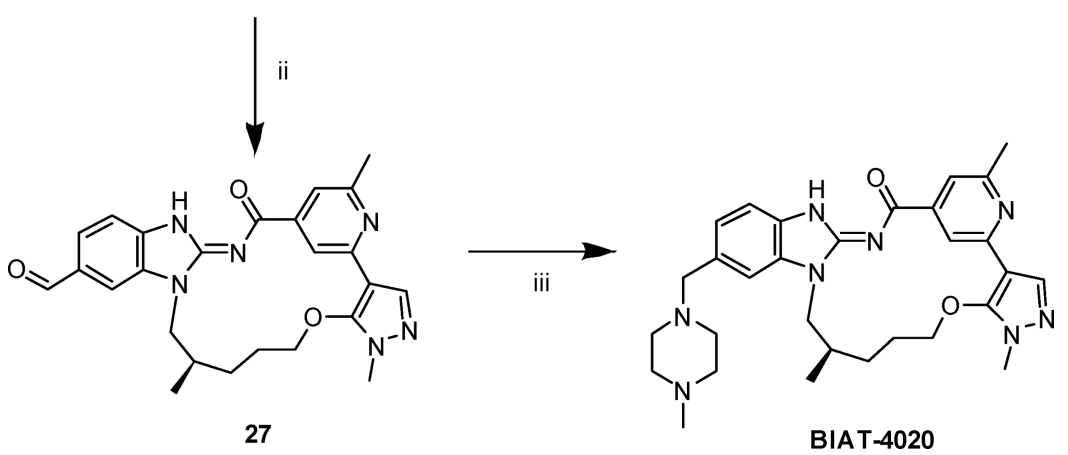

${ }^{a}$ Reagents and conditions: (i) $\mathrm{Pd} / \mathrm{C}, \mathrm{H}_{2}, \mathrm{MeOH}, 20{ }^{\circ} \mathrm{C}, 4 \mathrm{~h}$; (ii) $\mathrm{Pd}(\mathrm{OAc})_{2}$, di(1-adamantyl)- $n$-butylphosphine, TMEDA, $\mathrm{H}_{2} / \mathrm{CO}$, dioxane, 100 ${ }^{\circ} \mathrm{C}, 24 \mathrm{~h}$; (iii) $\mathrm{NaBH}(\mathrm{OAc})_{3}, \mathrm{HOAc}, \mathrm{CH}_{2} \mathrm{Cl}_{2}, 20^{\circ} \mathrm{C}, 6 \mathrm{~h}$.

Scheme 5. Synthesis of Compounds $16 a-c^{a}$<smiles>COC(=O)c1cc(C)nc(Cl)c1</smiles>

30

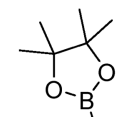<smiles>[R7]c1cc(C(=O)OC)ccn1</smiles>

32

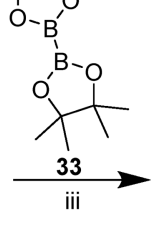

iii

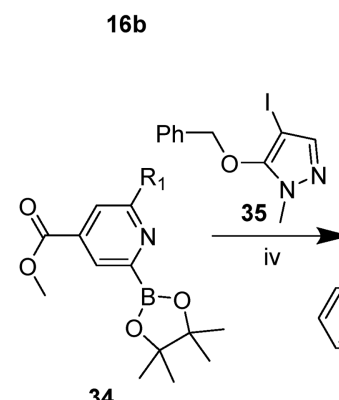

34

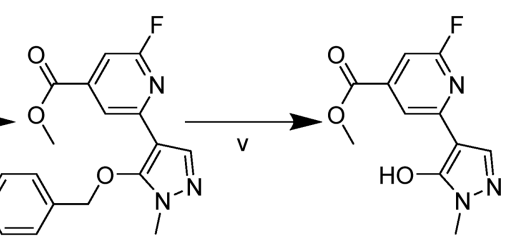

36

$16 c$

${ }^{a}$ Reagents and conditions: (i) $\mathrm{PdCl}_{2} \mathrm{DPPF}$, anisole, $\mathrm{Na}_{2} \mathrm{CO}_{3}, 130{ }^{\circ} \mathrm{C}, 16 \mathrm{~h}$; (ii) $\mathrm{PdCl}_{2} \mathrm{DPPF}$, dioxane, $\mathrm{K}_{2} \mathrm{CO}_{3}, 90{ }^{\circ} \mathrm{C}, 16 \mathrm{~h}$; (iii) (1,5cyclooctadiene)(methoxy)iridium(I) dimer, 4,4'-di-tert-butyl-2,2'-bipyridyl, $20^{\circ} \mathrm{C}$, $90 \mathrm{~h}$; (iv) $\mathrm{PdCl}_{2} \mathrm{DPPF}$, dioxane, $\mathrm{K}_{2} \mathrm{CO}_{3}, 90^{\circ} \mathrm{C}, 1 \mathrm{~h}$; (v) $\mathrm{Pd} / \mathrm{C}$, 5 bar $\mathrm{H}_{2}, \mathrm{MeOH}, 20{ }^{\circ} \mathrm{C}, 16 \mathrm{~h}$.

High-resolution mass spectrometry data were obtained on a LTQ Orbitrap XL (Thermo Scientific) coupled with a Triversa Nanomate Nanospray ion source (ADVION Bioscience Inc.).

Analytical HPLC-MS analyses were conducted using an Agilent 1100 series LC/MSD system. The analytic methods A1 and A2 are defined in Table S1. Compound purities were calculated as the percentage peak area of the analyzed compound by UV detection at $254 \mathrm{~nm}$. If purity data are not explicitly mentioned, the compound displays a purity $>95 \%$. Flash column chromatography was carried out using hand packed silica gel 60 (230-400 mesh) or prepacked silica gel columns from Biotage, and product was eluted under medium pressure liquid chromatography. Preparative high performance chromatography was carried out on a Gilson system (pump system, 333 and 334 prep-scale HPLC pump; fraction collector, 215 liquid handler; detector, Gilson UV/vis 155) using prepacked reversed phase silica gel columns from waters. The methods for preparative high performance chromatography P1-P3 are defined in Table S1. 


\section{Scheme 6. Synthesis of Compound $25^{a}$}

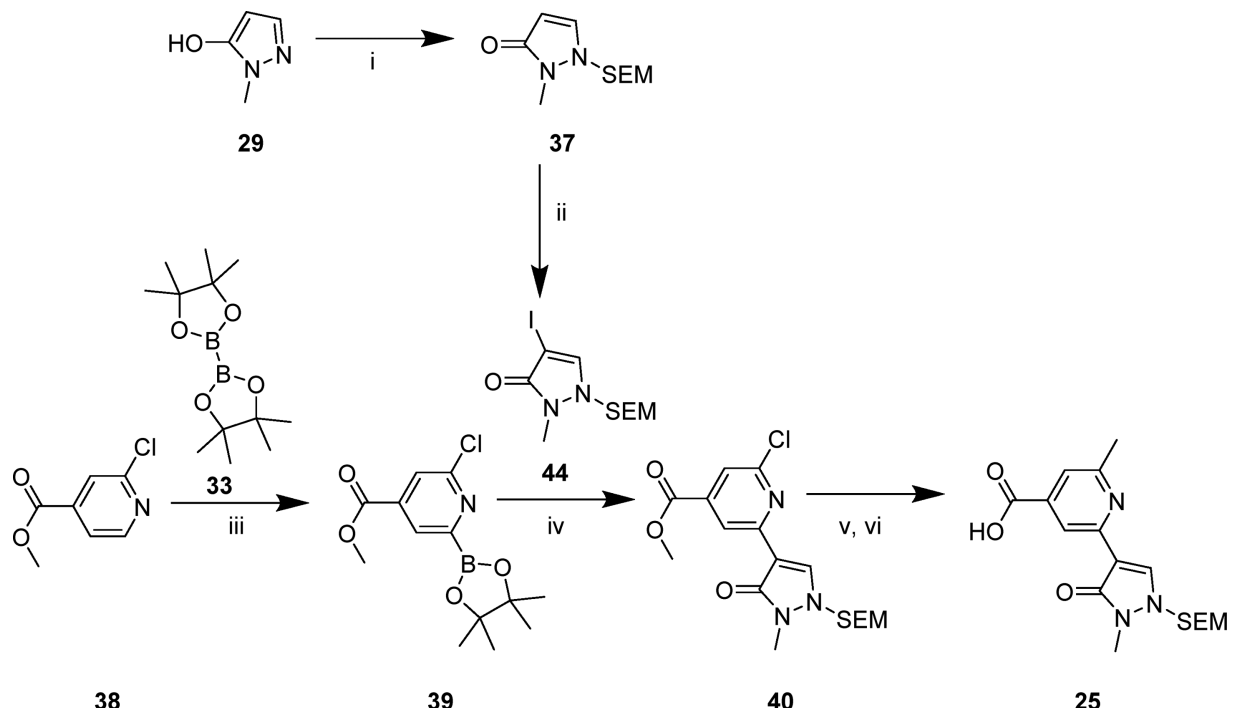

${ }^{a}$ Reagents and conditions: (i) SEM-Cl, $\mathrm{K}_{2} \mathrm{CO}_{3}$, ACN, $20{ }^{\circ} \mathrm{C}, 14 \mathrm{~h}$; (ii) NIS, ACN, 0-20 ${ }^{\circ} \mathrm{C}, 2 \mathrm{~h}$; (iii) (1,5-cyclooctadiene)(methoxy)iridium(I) dimer, 4,4'-di-tert-butyl-2,2'-bipyridyl, $20{ }^{\circ} \mathrm{C}, 66 \mathrm{~h}$; (iv) tris(dibenzylideneacetone)dipalladium, di(1-adamantyl)- $n$-butylphosphine, $\mathrm{Cs}_{2} \mathrm{CO}_{3}$, toluene, water, $50{ }^{\circ} \mathrm{C}, 2 \mathrm{~h}$; (v) trimethylboroxine, tris(dibenzylideneacetone)dipalladium, di(1-adamantyl)- $n$-butylphosphine, $\mathrm{Cs}_{2} \mathrm{CO}_{3}$, dioxane, 80 ${ }^{\circ} \mathrm{C}, 18 \mathrm{~h}$; (vi) $\mathrm{NaOH}, \mathrm{THF}, 20{ }^{\circ} \mathrm{C}, 1 \mathrm{~h}$.

\section{Scheme 7. Synthesis of Compound $15^{a}$}

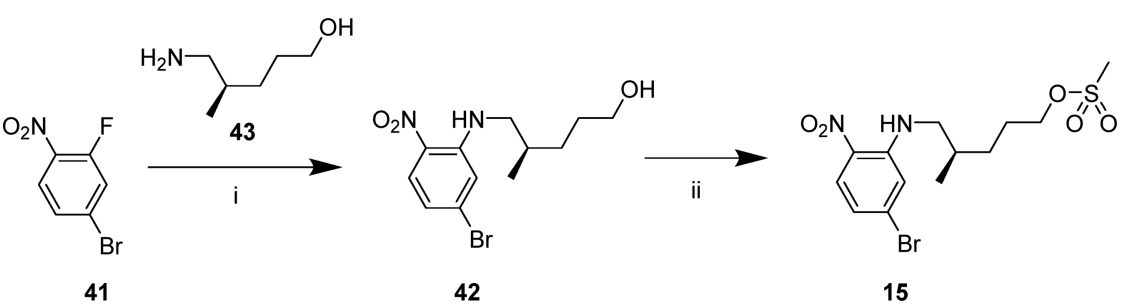

${ }^{a}$ Reagents and conditions: (i) $\mathrm{K}_{2} \mathrm{CO}_{3}, \mathrm{DMF}, 20^{\circ} \mathrm{C}, 24 \mathrm{~h}$; (ii) $\mathrm{MsCl}, \mathrm{NEt}_{3}, \mathrm{CH}_{2} \mathrm{Cl}_{2}, 0{ }^{\circ} \mathrm{C}, 1 \mathrm{~h}$.

The in vitro biological data shown in this publication are the geometric mean of at least three independent measurements.

All compounds for which biology data were shown were screened for PAINS, and none of them was classified as pan assay interference compound. ${ }^{59,60}$

3-Fluoro-N-[1-(2-hydroxy-2-methyl-propyl)-1H-benzoimidazol2-yl]-5-pyridin-3-yl-enzamide (1). Compound 1 was synthesized according to the procedure of compound 2.

Purity by method A1, >95\%; RT $=1.27 \mathrm{~min}$; MS $\left(\mathrm{ESI}^{+}\right) \mathrm{m} / z 405$ $(\mathrm{M}+\mathrm{H})^{+}$; HRMS $(m / z),[\mathrm{M}+\mathrm{H}]^{+}$calculated for $\mathrm{C}_{23} \mathrm{H}_{21} \mathrm{FN}_{4} \mathrm{O}_{2}$, 405.17213; found, 405.17126; ${ }^{1} \mathrm{H}$ NMR $\left(500 \mathrm{MHz}, \mathrm{DMSO}-d_{6}\right) \delta$ $12.85(\mathrm{br} \mathrm{s}, 1 \mathrm{H}), 8.97(\mathrm{~d}, J=2.21 \mathrm{~Hz}, 1 \mathrm{H}), 8.64(\mathrm{dd}, J=1.42,4.89$ $\mathrm{Hz}, 1 \mathrm{H}), 8.36(\mathrm{~s}, 1 \mathrm{H}), 8.17(\mathrm{td}, J=1.73,8.20 \mathrm{~Hz}, 1 \mathrm{H}), 7.95(\mathrm{dd}, J=$ $1.10,9.30 \mathrm{~Hz}, 1 \mathrm{H}), 7.78-7.83(\mathrm{~m}, 1 \mathrm{H}), 7.63(\mathrm{dd}, J=1.73,6.78 \mathrm{~Hz}$, $1 \mathrm{H}), 7.52-7.58(\mathrm{~m}, 2 \mathrm{H}), 7.24(\mathrm{ddd}, J=1.42,5.52,7.25 \mathrm{~Hz}, 2 \mathrm{H})$, $5.05(\mathrm{~s}, 1 \mathrm{H}), 4.25(\mathrm{~s}, 2 \mathrm{H}), 1.25(\mathrm{~s}, 6 \mathrm{H}) ;{ }^{13} \mathrm{C}$ NMR $(125 \mathrm{MHz}$, DMSO- $\left.d_{6}\right) \delta 171.3,162.6(\mathrm{~d}, J(\mathrm{CF})=243.4 \mathrm{~Hz}), 152.9,149.2,147.7$, $141.6(\mathrm{~d}, J(\mathrm{CF})=6.4 \mathrm{~Hz}), 139.2(\mathrm{~d}, J(\mathrm{CF})=8.2 \mathrm{~Hz}), 134.4,134.3$, $130.7,128.8,124.0,122.9,122.6,122.6,116.2(\mathrm{~d}, J(\mathrm{CF})=22.7 \mathrm{~Hz})$, $114.5(\mathrm{~d}, J(\mathrm{CF})=21.8 \mathrm{~Hz}), 111.9,111.7,71.0,52.8,27.9$.

$\mathrm{N}$-[1-(2-Hydroxy-2-methyl-propyl)-1H-benzoimidazol-2-yl]-5pyridin-3-yl-enzamide (2). 3-(Pyridin-3-yl)benzoic acid 13b (65 mg, $0.33 \mathrm{mmol}$ ) and 1-(2-amino-1H-benzo[d]imidazol-1-yl)-2-methylpropan-2-ol $14(65 \mathrm{mg}, 0.32 \mathrm{mmol})$ were dissolved in $2 \mathrm{~mL}$ of DMF, and HATU $(137 \mathrm{mg}, 0.36 \mathrm{mmol})$ and ethyldiisopropylamine $(163 \mu \mathrm{L}$, $0.95 \mathrm{mmol}$ ) were added. The reaction mixture was stirred for $3 \mathrm{~h}$ at room temperature. The volatile components have been evaporated under reduced pressure, and the crude product was purified applying preparative high performance chromatography method $\mathrm{P} 1$, yielding
$94 \mathrm{mg}(75 \%, 0.24 \mathrm{mmol})$ of the title compound. Purity by method $\mathrm{Al},>95 \%$; RT $=1.21 \mathrm{~min}$; $\mathrm{MS}\left(\mathrm{ESI}^{+}\right) \mathrm{m} / z 387(\mathrm{M}+\mathrm{H})^{+}$; HRMS $(m / z),[\mathrm{M}+\mathrm{H}]^{+}$calculated for $\mathrm{C}_{23} \mathrm{H}_{22} \mathrm{~N}_{4} \mathrm{O}_{2}, 387.18155$; found, 387.18221; ${ }^{1} \mathrm{H}$ NMR (500 MHz, DMSO- $d_{6}$ ) $\delta 12.87$ (br s, $1 \mathrm{H}$ ), 8.94 $(\mathrm{d}, J=1.58 \mathrm{~Hz}, 1 \mathrm{H}), 8.62(\mathrm{dd}, J=1.58,4.73 \mathrm{~Hz}, 1 \mathrm{H}), 8.51(\mathrm{~s}, 1 \mathrm{H})$, $8.23-8.30(\mathrm{~m}, 1 \mathrm{H}), 8.12-8.16(\mathrm{~m}, 1 \mathrm{H}), 7.85-7.92(\mathrm{~m}, 1 \mathrm{H}), 7.61-$ $7.66(\mathrm{~m}, 2 \mathrm{H}), 7.53-7.59(\mathrm{~m}, 1 \mathrm{H}), 7.55(\mathrm{dd}, J=1.58,6.31 \mathrm{~Hz}, 1 \mathrm{H})$, 7.23 (s, 2H), 5.11 (br s, $1 \mathrm{H}), 4.25(\mathrm{~s}, 2 \mathrm{H}), 1.25(\mathrm{~s}, 6 \mathrm{H}) ;{ }^{13} \mathrm{C} \mathrm{NMR}$ $\left(125 \mathrm{MHz}, \mathrm{DMSO}-d_{6}\right) \delta 172.6,152.9,148.6,147.5,139.0,136.8$, $135.6,134.3,130.7,129.6,129.0,129.0,128.3,126.9,124.1,122.5$, 111.9, 111.5, 71.0, 52.9, 27.8. Compounds 1 and 3-5 were synthesized accordingly.

[2,3']Bipyridinyl-4-carboxylic Acid [1-(2-Hydroxy-2-methyl-propyl)-1H-benzoimidazol-2-yl]-amide (3). Compound 3 was synthesized according to the procedure of compound 2 .

Purity by method A1, >95\%; RT $=1.10 \mathrm{~min}$; $\mathrm{MS}\left(\mathrm{ESI}^{+}\right) \mathrm{m} / z 388$ $(\mathrm{M}+\mathrm{H})^{+}$; HRMS $(m / z),[\mathrm{M}+\mathrm{H}]^{+}$calculated for $\mathrm{C}_{22} \mathrm{H}_{21} \mathrm{~N}_{5} \mathrm{O}_{2}$, 388.17680; found, 388.1771; ${ }^{1} \mathrm{H}$ NMR (500 MHz, DMSO- $d_{6}$ ) $\delta$ $12.94($ br s, $1 \mathrm{H}), 9.28(\mathrm{~d}, J=1.89 \mathrm{~Hz}, 1 \mathrm{H}), 8.87(\mathrm{~d}, J=5.04 \mathrm{~Hz}, 1 \mathrm{H})$, $8.68(\mathrm{dd}, J=1.26,4.73 \mathrm{~Hz}, 1 \mathrm{H}), 8.59(\mathrm{~s}, 1 \mathrm{H}), 8.45-8.49(\mathrm{~m}, 1 \mathrm{H})$, $8.09(\mathrm{dd}, J=1.10,4.89 \mathrm{~Hz}, 1 \mathrm{H}), 7.64-7.68(\mathrm{~m}, 1 \mathrm{H}), 7.55-7.61(\mathrm{~m}$, $2 \mathrm{H})$, 7.22-7.30 (m, $2 \mathrm{H}), 4.97-5.04(\mathrm{~m}, 1 \mathrm{H}), 4.22-4.32(\mathrm{~m}, 2 \mathrm{H})$, $1.26(\mathrm{~s}, 6 \mathrm{H}) ;{ }^{13} \mathrm{C}$ NMR $\left(125 \mathrm{MHz}, \mathrm{DMSO}-d_{6}\right) \delta 171.1,154.4,152.8$, $150.5,150.0,147.7,146.7,134.1,134.0,130.7,128.8,123.9,122.7$, $122.7,121.9,119.0,112.0,111.9,71.0,52.9,27.9$.

4'-Methoxy-[2,3']bipyridinyl-4-carboxylic Acid [1-(2-Hydroxy-2methyl-propyl)-1H-benzoimidazol-2-yl]-amide (3a). Compound 3a was synthesized according to the procedure of compound 2 . 
Purity by method A1, >95\%; RT $=1.08 \mathrm{~min}$; MS $\left(\mathrm{ESI}^{+}\right) \mathrm{m} / z 418$ $(\mathrm{M}+\mathrm{H})^{+}$; HRMS $(m / z),[\mathrm{M}+\mathrm{H}]^{+}$calculated for $\mathrm{C}_{23} \mathrm{H}_{23} \mathrm{~N}_{5} \mathrm{O}_{3}$, 418.18737; found, 418.18740; ${ }^{1} \mathrm{H}$ NMR (500 MHz, DMSO- $d_{6}$ ) $\delta$ $12.68-13.22(\mathrm{~m}, 1 \mathrm{H}), 8.80(\mathrm{br} \mathrm{d}, J=4.73 \mathrm{~Hz}, 1 \mathrm{H}), 8.61(\mathrm{~s}, 1 \mathrm{H}), 8.52$ (br s, $1 \mathrm{H}), 8.05(\mathrm{dd}, J=1.26,5.04 \mathrm{~Hz}, 1 \mathrm{H}), 7.83(\mathrm{~d}, J=8.20 \mathrm{~Hz}$, $1 \mathrm{H}), 7.63(\mathrm{~d}, J=8.20 \mathrm{~Hz}, 1 \mathrm{H}), 7.24-7.29(\mathrm{~m}, 1 \mathrm{H}), 7.22(\mathrm{~d}, J=5.67$ $\mathrm{Hz}, 1 \mathrm{H}), 7.15(\mathrm{t}, J=7.57 \mathrm{~Hz}, 1 \mathrm{H}), 7.03(\mathrm{t}, J=7.57 \mathrm{~Hz}, 1 \mathrm{H}), 5.01(\mathrm{~s}$, $1 \mathrm{H}), 4.31-4.41(\mathrm{~m}, 2 \mathrm{H}), 3.79(\mathrm{~s}, 3 \mathrm{H}), 1.26(\mathrm{~s}, 6 \mathrm{H}) ;{ }^{13} \mathrm{C}$ NMR $(125$ $\left.\mathrm{MHz}, \mathrm{DMSO}-d_{6}\right) \delta 168.8,162.6,156.5,153.0,151.4,150.9,150.0$, $146.0,138.0,132.9,124.0,123.8,121.6,121.5,121.2,116.4,111.3$, $107.6,71.1,55.8,52.9,27.9$.

$\mathrm{N}$-[1-(2-Hydroxy-2-methyl-propyl)-1H-benzoimidazol-2-yl]-2-(1methyl-1H-pyrazol-4-yl)-isonicotinamide (4). Compound 4 was synthesized according to the procedure of compound 2 .

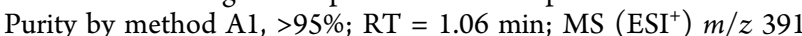
$(\mathrm{M}+\mathrm{H})^{+}$; HRMS $(m / z),[\mathrm{M}+\mathrm{H}]^{+}$calculated for $\mathrm{C}_{21} \mathrm{H}_{22} \mathrm{~N}_{6} \mathrm{O}_{2}$, 391.18770; found, 391.18765; ${ }^{1} \mathrm{H}$ NMR (500 MHz, DMSO-d $\left.d_{6}\right) \delta$ 12.88 (br s, 1H), $8.64(\mathrm{dd}, J=0.63,5.04 \mathrm{~Hz}, 1 \mathrm{H}), 8.33(\mathrm{~s}, 1 \mathrm{H}), 8.21$ $(\mathrm{s}, 1 \mathrm{H}), 8.01(\mathrm{~s}, 1 \mathrm{H}), 7.84(\mathrm{dd}, J=1.26,4.73 \mathrm{~Hz}, 1 \mathrm{H}), 7.63-7.68(\mathrm{~m}$, $1 \mathrm{H}), 7.57(\mathrm{dd}, J=1.42,7.41 \mathrm{~Hz}, 1 \mathrm{H}), 7.21-7.29(\mathrm{~m}, 2 \mathrm{H}), 5.00(\mathrm{~s}$, $1 \mathrm{H}), 4.26(\mathrm{~s}, 2 \mathrm{H}), 3.92(\mathrm{~s}, 3 \mathrm{H}), 1.26(\mathrm{~s}, 6 \mathrm{H}) ;{ }^{13} \mathrm{C}$ NMR $(125 \mathrm{MHz}$, DMSO- $\left.d_{6}\right) \delta 171.5,152.8,152.1,149.9,146.1,136.9,130.7,129.6$, $128.8,122.8,122.7,122.6,119.7,117.7,112.0,111.9,71.0,52.8,38.8$, 27.8 .

N-[1-(2-Hydroxy-2-methyl-propyl)-1H-benzoimidazol-2-yl]-2phenyl-isonicotinamide (5). Compound $\mathbf{5}$ was synthesized according to the procedure of compound 2.

Purity by method A1, >95\%; RT $=1.31 \mathrm{~min}$; $\mathrm{MS}\left(\mathrm{ESI}^{+}\right) \mathrm{m} / z 387$ $(\mathrm{M}+\mathrm{H})^{+}$; HRMS $(m / z),[\mathrm{M}+\mathrm{H}]^{+}$calculated for $\mathrm{C}_{23} \mathrm{H}_{22} \mathrm{~N}_{4} \mathrm{O}_{2}$, 387.18155; found, 387.18197; ${ }^{1} \mathrm{H}$ NMR (500 MHz, DMSO- $\left.d_{6}\right) \delta$ $12.93(\mathrm{br} \mathrm{s}, 1 \mathrm{H}), 8.82(\mathrm{~d}, J=5.04 \mathrm{~Hz}, 1 \mathrm{H}), 8.55(\mathrm{~s}, 1 \mathrm{H}), 8.11(\mathrm{~d}, J=$ $7.57 \mathrm{~Hz}, 2 \mathrm{H}), 8.03(\mathrm{~d}, J=5.04 \mathrm{~Hz}, 1 \mathrm{H}), 7.66(\mathrm{br} \mathrm{d}, J=7.25 \mathrm{~Hz}, 1 \mathrm{H})$, 7.52-7.59 (m, 3H), 7.45-7.51 (m, 1H), 7.21-7.29 (m, 2H), $5.02(\mathrm{~s}$, $1 \mathrm{H}), 4.27(\mathrm{~s}, 2 \mathrm{H}), 1.27(\mathrm{~s}, 6 \mathrm{H}) ;{ }^{13} \mathrm{C}$ NMR $\left(125 \mathrm{MHz}, \mathrm{DMSO}-d_{6}\right) \delta$ $171.3,156.6,152.8,150.2,146.5,138.7,130.7,129.2,128.9,128.8$, $126.5,122.7,122.7,121.2,118.6,112.0,111.9,71.0,52.9,27.9$.

$5^{1} \mathrm{H}$-11-Oxa-4-aza-5(2,1)-benzo[d]imidazola-2(2,4)-pyridina-1(1,2)-benzenacycloundecaphan-3-one (6). 2-\{2-[5-(2-Imino-2,3dihydro-benzimidazol-1-yl)-pentyloxy]-phenyl $\}$-isonicotinic acid tertbutyl ester $22 \mathbf{b}(186 \mathrm{mg}, 0.39 \mathrm{mmol})$ was dissolved in dichloromethane, and trifluoroacetic acid $(0.45 \mathrm{~mL}, 5.60 \mathrm{mmol})$ was added at room temperature. The reaction mixture was stirred for $20 \mathrm{~h}$ at room temperature. After complete conversion to product, the mixture was concentrated under reduced pressure. The residue was resolved in dichloromethane neutralized with $5 \mathrm{~mL}$ of $\mathrm{Et}_{3} \mathrm{~N}$, and the mixture was concentrated under reduced pressure again. The crude product was used in the next step without further purification, and yield was estimated as quantitative.

2-\{2-[5-(2-Imino-2,3-dihydro-benzoimidazol-1-yl)-pentyloxy]-phenyl $\}$-isonicotonic acid as a crude product $(160 \mathrm{mg}, 0.38 \mathrm{mmol})$ was dissolved in dichloromethane, and $0.17 \mathrm{~mL} \mathrm{Et}_{3} \mathrm{~N}$ (1.15 mmol) was added at room temperature. The solution was stirred for $30 \mathrm{~min}$ at room temperature, and HATU ( $164 \mathrm{mg}, 0.42 \mathrm{mmol})$ was added. The reaction mixture was stirred for $16 \mathrm{~h}$ at room temperature. After complete conversion, to the reaction mixture was added water, and it was extracted with dichloromethane. Collected organic layers were dried over $\mathrm{MgSO}_{4}$ and concentrated under reduced pressure. The crude product was purified applying preparative high performance chromatography method $\mathrm{P} 3$ yielding $23 \mathrm{mg}$ ( $15 \%, 0.058 \mathrm{mmol})$ of the title compound.

Purity by method A1, >95\%; RT $=1.48 \mathrm{~min}$; $\mathrm{MS}\left(\mathrm{ESI}^{+}\right) \mathrm{m} / z 399$ $(\mathrm{M}+\mathrm{H})^{+}$; HRMS $(m / z),[\mathrm{M}+\mathrm{H}]^{+}$calculated for $\mathrm{C}_{24} \mathrm{H}_{22} \mathrm{~N}_{4} \mathrm{O}_{2}$, 399.18155; found, 399.18060; ${ }^{1} \mathrm{H}$ NMR (500 MHz, DMSO-d $\left.d_{6}\right) \delta$ $12.75(\mathrm{~s}, 1 \mathrm{H}), 9.25(\mathrm{~s}, 1 \mathrm{H}), 8.80(\mathrm{dd}, J=0.63,5.04 \mathrm{~Hz}, 1 \mathrm{H}), 8.24$ $(\mathrm{dd}, J=1.73,7.72 \mathrm{~Hz}, 1 \mathrm{H}), 7.80(\mathrm{dd}, J=1.42,4.89 \mathrm{~Hz}, 1 \mathrm{H}), 7.51-$ $7.58(\mathrm{~m}, 2 \mathrm{H}), 7.42(\mathrm{ddd}, J=1.89,7.01,8.43 \mathrm{~Hz}, 1 \mathrm{H}), 7.28(\mathrm{dtd}, J=$ $0.95,7.65,19.39 \mathrm{~Hz}, 2 \mathrm{H}), 7.19(\mathrm{~d}, J=7.88 \mathrm{~Hz}, 1 \mathrm{H}), 7.09(\mathrm{t}, J=7.30$ $\mathrm{Hz}, 1 \mathrm{H}), 4.23(\mathrm{td}, J=5.00,17.10 \mathrm{~Hz}, 4 \mathrm{H}), 1.86-2.11(\mathrm{~m}, 6 \mathrm{H}) ;{ }^{13} \mathrm{C}$ NMR (125 MHz, DMSO-d $\left.d_{6}\right) \delta 172.4,157.0,154.4,152.2,149.6$,
$145.8,130.5,130.5,129.3,128.9,126.4,124.2,122.9,122.8,120.5$, $120.1,112.6,112.1,109.5,67.9,41.2,28.7,28.7,24.9$.

(E)-26-Fluoro- $1^{1}$-methyl- $5^{2}, 5^{3}$-dihydro- $1^{1} \mathrm{H}, 5^{1} \mathrm{H}-11$-oxa-4-aza-5$(2,1)$-benzo[d]imidazola-2(2,4)-pyridina-1 $(4,5)$-pyrazolacycloundecaphan-3-one (7). 2-(5-\{[5-(2-Amino-1H-1,3-benzodiazol-1-yl]pentyloxy\}-1-methyl-1H-pyrazol-4-yl)-6-fluoropyridine-4-carboxylic acid $22 \mathrm{c}(30 \mathrm{mg}, 0.068 \mathrm{mmol})$ and HATU $(29 \mathrm{mg}, 0.075 \mathrm{mmol})$ were suspended in $2 \mathrm{~mL}$ of dichloromethane, and $40 \mu \mathrm{L}$ of ${ }^{i} \operatorname{Pr}_{2} \mathrm{EtN}(0.21$ $\mathrm{mmol}$ ) was added at room temperature. The reaction mixture was stirred for $16 \mathrm{~h}$ at room temperature. After complete conversion time, volatile components have been evaporated under reduced pressure.

The crude product was purified by applying preparative high performance chromatography method P3 yielding $20 \mathrm{mg}$ (70\%) of the title compound.

Purity by method A1, >95\%; RT = $1.34 \mathrm{~min}$; $\mathrm{MS}\left(\mathrm{ESI}^{+}\right) \mathrm{m} / z 421$ $(\mathrm{M}+\mathrm{H})^{+}$; HRMS $(m / z),[\mathrm{M}+\mathrm{H}]^{+}$calculated for $\mathrm{C}_{22} \mathrm{H}_{21} \mathrm{FN}_{6} \mathrm{O}_{2}$ 421.17828; found, 421.17800; ${ }^{1} \mathrm{H}$ NMR (500 MHz, DMSO- $\left.d_{6}\right) \delta$ $12.78(\mathrm{~s}, 1 \mathrm{H}), 8.49(\mathrm{~s}, 1 \mathrm{H}), 7.88(\mathrm{~s}, 1 \mathrm{H}), 7.62(\mathrm{~d}, J=7.88 \mathrm{~Hz}, 1 \mathrm{H})$, $7.55(\mathrm{~d}, J=7.57 \mathrm{~Hz}, 1 \mathrm{H}), 7.20-7.34(\mathrm{~m}, 3 \mathrm{H}), 4.11-4.30(\mathrm{~m}, 4 \mathrm{H})$, $3.74(\mathrm{~s}, 3 \mathrm{H}), 2.05(\mathrm{br} \mathrm{d}, J=6.62 \mathrm{~Hz}, 4 \mathrm{H}), 1.73-1.88(\mathrm{~m}, 2 \mathrm{H}) ;{ }^{13} \mathrm{C}$ NMR $\left(125 \mathrm{MHz}, \mathrm{DMSO}-d_{6}\right) \delta 170.2(\mathrm{~d}, J(\mathrm{CF})=3.6 \mathrm{~Hz}), 163.9(\mathrm{~d}$, $J(\mathrm{CF})=234.3 \mathrm{~Hz}), 152.9(\mathrm{~d}, J(\mathrm{CF})=7.3 \mathrm{~Hz}), 152.0,151.7,150.1(\mathrm{~d}$, $J(\mathrm{CF})=14.5 \mathrm{~Hz}), 137.5,129.8,129.3,123.5,123.3,116.7(\mathrm{~d}, J(\mathrm{CF})$ $=2.7 \mathrm{~Hz}), 112.8,110.1,107.0,104.4(\mathrm{~d}, J(\mathrm{CF})=39.1 \mathrm{~Hz}), 72.3,42.9$, 34.7, 28.0, 25.4, 21.9 .

(E)-1 $1^{1}, 2^{6}$-Dimethyl- $5^{2}, 5^{3}$-dihydro- $1^{1} H, 5^{1} H$-11-oxa-4-aza-5 $(2,1)$ benzo[d]imidazola-2(2,4)-pyridina-1 $(4,5)$-pyrazolacycloundecaphan-3-one (8). (E)-2-(5-Hydroxy-1-methyl-1H-pyrazol-4-yl)-N-(1(5-hydroxypentyl)-1,3-dihydro-2H-benzo[d]imidazol-2-ylidene)-6methylisonicotinamide $26(50 \mathrm{mg}, 0.12 \mathrm{mmol})$ was dissolved in $5 \mathrm{~mL}$ of anhydrous tetrahydrofuran. Diisopropyl azodicarboxylate $(100 \mu \mathrm{L}$, $0.48 \mathrm{mmol}$ ) was added, and the reaction vessel was purged with argon. Triphenylphosphine $(130 \mathrm{mg}, 0.47 \mathrm{mmol})$ was added, and the reaction mixture was stirred at room temperature. After completion of the reaction, water was added and the reaction mixture was extracted with dichloromethane. The combined organic layers were dried over magnesium sulfate and concentrated. The residue was purified applying preparative high performance chromatography (method $\mathrm{P} 1)$, yielding $31 \mathrm{mg}(65 \%, 0.07 \mathrm{mmol})$ of the title compound.

Purity by method A1, >95\%; RT $=1.30 \mathrm{~min}$; MS $\left(\mathrm{ESI}^{+}\right) \mathrm{m} / z 417$ $(\mathrm{M}+\mathrm{H})^{+}$; HRMS $(m / z),[\mathrm{M}+\mathrm{H}]^{+}$calculated for $\mathrm{C}_{23} \mathrm{H}_{24} \mathrm{~N}_{6} \mathrm{O}_{2}$, 417.20335; found, 417.20338; ${ }^{1} \mathrm{H}$ NMR (500 MHz, DMSO-d $\left.d_{6}\right) \delta$ $12.67(\mathrm{br} \mathrm{s}, 1 \mathrm{H}), 8.41(\mathrm{~s}, 1 \mathrm{H}), 7.92(\mathrm{~s}, 1 \mathrm{H}), 7.59(\mathrm{~d}, J=7.57 \mathrm{~Hz}$, $1 \mathrm{H}), 7.57(\mathrm{~d}, J=0.63 \mathrm{~Hz}, 1 \mathrm{H}), 7.54(\mathrm{~d}, J=7.50 \mathrm{~Hz}, 1 \mathrm{H}), 7.28(\mathrm{ddd}, J$ $=1.50,7.00,8.10 \mathrm{~Hz}, 1 \mathrm{H}$ ), 7.23 (ddd, $J=1.00,7.00,8.10 \mathrm{~Hz}, 1 \mathrm{H})$, $4.17-4.24(\mathrm{~m}, 4 \mathrm{H}), 3.73(\mathrm{~s}, 3 \mathrm{H}), 2.56(\mathrm{~s}, 3 \mathrm{H}), 1.99-2.12(\mathrm{~m}, 4 \mathrm{H})$, $1.75-1.84(\mathrm{~m}, 2 \mathrm{H}) ;{ }^{13} \mathrm{C}$ NMR $\left(125 \mathrm{MHz}\right.$, DMSO- $\left.d_{6}\right) \delta 171.6,158.0$, $151.7,150.7,150.4,146.3,136.9,129.4,128.9,122.8,122.6,118.2$, 115.7, 112.2, 109.4, 107.8, 71.6, 42.3, 34.1, 27.5, 24.8, 24.5, 21.3.

$(R, E)-1^{1}, 2^{6}, 7-T r i m e t h y l-5^{2}, 5^{3}$-dihydro- $1^{1} \mathrm{H}, 5^{1} \mathrm{H}-11$-oxa-4-aza-5$(2,1)$-benzo[d]imidazola-2(2,4)-pyridina-1 $(4,5)$-pyrazolacycloundecaphan-3-one (9). (R,E)-5 - $5^{6}$-Bromo- $1^{1}, 2^{6}, 7$-trimethyl- $5^{2}, 5^{3}$-dihydro$11 \mathrm{H}, 51 \mathrm{H}$-11-oxa-4-aza-5(2,1)-benzo[d]imidazola-2(2,4)-pyridina-1(4,5)-pyrazolacycloundecaphan-3-one $9 \mathrm{Br}(100 \mathrm{mg}, 0.20 \mathrm{mmol})$ was dissolved in $3 \mathrm{~mL}$ of DMF, and then triethysilane $(0.32 \mathrm{~mL}, 1.91$ $\mathrm{mmol})$, sodium carbonate $(72 \mathrm{mg}, 0.68 \mathrm{mmol})$, and $\left[1,1^{\prime}\right.$ bis(diphenylphosphino)ferrocene] dichloropalladium(II) (4 mg, $0,005 \mathrm{mmol}$ ) were added at $25{ }^{\circ} \mathrm{C}$. The reaction mixture was stirred at $90{ }^{\circ} \mathrm{C}$ for $16 \mathrm{~h}$, and afterward it was filtered over Celite and the solvents were removed under reduced pressure. The residue was purified applying preparative high performance chromatography (method P1), yielding $21 \mathrm{mg}(25 \%, 0.05 \mathrm{mmol})$ of the title compound.

Purity by method A1, >95\%; RT = $1.36 \mathrm{~min}$; MS $\left(\mathrm{ESI}^{+}\right) \mathrm{m} / z 431$ $(\mathrm{M}+\mathrm{H})^{+} ;{ }^{1} \mathrm{H}$ NMR $\left(500 \mathrm{MHz}, \mathrm{DMSO}-d_{6}\right) \delta 12.74($ br s, $1 \mathrm{H}), 8.43$ $(\mathrm{s}, 1 \mathrm{H}), 7.92(\mathrm{~s}, 1 \mathrm{H}), 7.60(\mathrm{~d}, J=7.88 \mathrm{~Hz}, 1 \mathrm{H}), 7.57(\mathrm{~s}, 1 \mathrm{H}), 7.55(\mathrm{~d}$, $J=7.57 \mathrm{~Hz}, 1 \mathrm{H}), 7.28(\mathrm{t}, J=7.70 \mathrm{~Hz}, 1 \mathrm{H}), 7.23(\mathrm{t}, J=7.70 \mathrm{~Hz}, 1 \mathrm{H})$, $4.35(\mathrm{td}, J=4.49,9.30 \mathrm{~Hz}, 1 \mathrm{H}), 4.20(\mathrm{dd}, J=2.84,13.56 \mathrm{~Hz}, 1 \mathrm{H})$, $3.97-4.04(\mathrm{~m}, 1 \mathrm{H}), 3.93(\mathrm{dd}, J=10.40,13.56 \mathrm{~Hz}, 1 \mathrm{H}), 3.73(\mathrm{~s}, 3 \mathrm{H})$, $2.80(\mathrm{br} \mathrm{d}, J=3.47 \mathrm{~Hz}, 1 \mathrm{H}), 2.56(\mathrm{~s}, 3 \mathrm{H}), 2.15-2.27(\mathrm{~m}, 1 \mathrm{H}), 1.85-$ 
$2.04(\mathrm{~m}, 2 \mathrm{H}), 1.39-1.51(\mathrm{~m}, 1 \mathrm{H}), 0.81(\mathrm{~d}, J=6.62 \mathrm{~Hz}, 3 \mathrm{H}) ;{ }^{13} \mathrm{C}$ NMR (125 MHz, DMSO- $\left.d_{6}\right) \delta 171.3,158.0,151.6,150.8,150.4$, $146.2,136.9,130.4,128.8,122.9,122.5,118.2,115.7,112.2,109.7$, $107.8,71.3,49.4,34.1,28.8,28.7,25.5,24.5,16.8$.

$(R, E)$ - $5^{6}$-Bromo-1 ${ }^{1}, 2^{6}, 7$-trimethyl- $5^{2}, 5^{3}$-dihydro- $11 \mathrm{H}, 51 \mathrm{H}$-11-oxa4-aza-5(2,1)-benzo[d] imidazola-2(2,4)-pyridina-1 $(4,5)$-pyrazolacycloundecaphan-3-one (9Br). (R)-2-(5-((5-(2-Amino-6-bromo-1Hbenzo[d]imidazol-1-yl)-4-methylpentyl)oxy)-1-methyl-1 $H$-pyrazol-4yl)-6-methylisonicotinic acid 22a' (9.70 g, $18.4 \mathrm{mmol})$ was dissolved in $\mathrm{CH}_{2} \mathrm{Cl}_{2}(200 \mathrm{~mL})$, and $\mathrm{Et}_{3} \mathrm{~N}(10.3 \mathrm{~mL}, 73.6 \mathrm{mmol})$ was added. To the resultant solution was added TBTU $(7.09 \mathrm{~g}, 22.1 \mathrm{mmol})$, and the reaction mixture was stirred at room temperature for $15 \mathrm{~min}$. The reaction mixture was washed with water $(3 \times 100 \mathrm{~mL})$, and the organic phase was dried over $\mathrm{Na}_{2} \mathrm{SO}_{4}$, filtered, and concentrated under reduced pressure. The crude product was purified by chromatography on $\mathrm{SiO}_{2}$ using $\mathrm{CH}_{2} \mathrm{Cl}_{2} / \mathrm{MeOH}$ (100:0 to 95:5) as eluent. The resultant material was further purified by recrystallization from hot toluene to give the title compound $(5.24 \mathrm{~g}, 10.3 \mathrm{mmol}, 56 \%)$ as a white solid. Purity by method A1, $>95 \%$; RT $=1.46 \mathrm{~min}$; MS $\left(\mathrm{ESI}^{+}\right) \mathrm{m} / z$ 509/511 $(\mathrm{M}+\mathrm{H})^{+}$; HRMS $(m / z),[\mathrm{M}+\mathrm{H}]^{+}$calculated for $\mathrm{C}_{24} \mathrm{H}_{25} \mathrm{BrN}_{6} \mathrm{O}_{2}, 509.12948$; found, 509.12799; ${ }^{1} \mathrm{H}$ NMR (400 MHz, DMSO-d $\left.d_{6}\right) \delta 12.84$ (br s, $\left.1 \mathrm{H}\right), 8.41(\mathrm{~s}, 1 \mathrm{H}), 7.92(\mathrm{~s}, 2 \mathrm{H}), 7.56$ $(\mathrm{s}, 1 \mathrm{H}), 7.47(\mathrm{~d}, J=8.40 \mathrm{~Hz}, 1 \mathrm{H}), 7.39(\mathrm{dd}, J=1.80,8.40 \mathrm{~Hz}, 1 \mathrm{H})$, 4.28-4.41 (m, $1 \mathrm{H}), 4.11-4.20(\mathrm{~m}, 1 \mathrm{H}), 3.93-4.05(\mathrm{~m}, 2 \mathrm{H}), 3.73(\mathrm{~s}$, $3 \mathrm{H}), 2.72-2.87(\mathrm{~m}, 1 \mathrm{H}), 2.56(\mathrm{~s}, 3 \mathrm{H}), 2.14-2.28(\mathrm{~m}, 1 \mathrm{H}), 1.84-$ $2.05(\mathrm{~m}, 2 \mathrm{H}), 1.37-1.51(\mathrm{~m}, 1 \mathrm{H}), 0.81(\mathrm{~d}, J=6.59 \mathrm{~Hz}, 3 \mathrm{H}) ;{ }^{13} \mathrm{C}$ NMR (100 MHz, DMSO- $\left.d_{6}\right) \delta 172.1,158.5,152.4,151.2,150.9$, $146.4,137.4,132.4,128.6,125.7,118.6,116.2,115.5,114.3,113.0$, 108.2, 71.7, 50.0, 34.6, 29.1, 29.0, 26.0, 24.9, 17.1.

$(R, E)-11,26,7-T r i m e t h y l-56-((4-m e t h y l p i p e r a z i n-1-y l) m e t h y l)-$ 52,53-dihydro-11H,51H-11-oxa-4-aza-5(2,1)-benzo[d]imidazola-2$(2,4)$-pyridina-1(4,5)-pyrazolacycloundecaphan-3-one (BI-4020). $(R, E)-11,26,7-T r i m e t h y l-3-o x o-52,53$-dihydro- $11 \mathrm{H}, 51 \mathrm{H}$-11-oxa-4-aza5(2,1)-benzo[ $d]$ imidazola-2(2,4)-pyridina-1 (4,5)-pyrazolacycloundecaphane-56-carbaldehyde $27(2.00 \mathrm{~g}, 3.82 \mathrm{mmol}, 87 \%$ purity $)$ and 1methylpiperazine $(2.83 \mathrm{~g}, 28.25 \mathrm{mmol})$ were dissolved in $40 \mathrm{~mL}$ of $\mathrm{DCM}$, and $\mathrm{AcOH}(1.99 \mathrm{~g}, 19.86 \mathrm{mmol})$ and sodium triacetoxyborohydride $(2.26 \mathrm{~g}, 10.7 \mathrm{mmol})$ were added sequentially. The reaction mixture was stirred for $6 \mathrm{~h}$ at room temperature. The reaction was quenched with satd $\mathrm{NaHCO}_{3}(15 \mathrm{~mL})$, and the volatile components were evaporated under reduced pressure. The crude residue was partitioned between 2-methyltetrahydrofuran $(25 \mathrm{~mL})$ and satd $\mathrm{NH}_{4} \mathrm{Cl}(20 \mathrm{~mL})$, and the resulting organic layer was washed with $5 \%$ brine $(25 \mathrm{~mL})$. The final organic layer was dried over magnesium sulfate and concentrated under reduced pressure to dryness, and the crude product was purified by Combiflash using $10 \% \mathrm{MeOH}$ in DCM $\left(R_{f} 0.18\right.$ in $10 \% \mathrm{MeOH}$ in DCM) yielding $1.5 \mathrm{~g}$ of off-white foam $(72.4 \%, 2.76 \mathrm{mmol})$ of the desired product BI-4020. Purity by method Al, >95\%; RT = $1.26 \mathrm{~min}$; $\mathrm{MS}\left(\mathrm{ESI}^{+}\right) \mathrm{m} / z 543(\mathrm{M}+\mathrm{H})^{+}$; HRMS $(m / z),[\mathrm{M}+\mathrm{H}]^{+}$calculated for $\mathrm{C}_{30} \mathrm{H}_{38} \mathrm{~N}_{8} \mathrm{O}_{2}, 543.31905$; found, 543.31976; ${ }^{1} \mathrm{H}$ NMR (500 MHz, DMSO- $d_{6}$ ) $\delta 12.67$ (br s, $1 \mathrm{H}), 8.42(\mathrm{~s}, 1 \mathrm{H}), 7.92(\mathrm{~s}, 1 \mathrm{H}), 7.56(\mathrm{~s}, 1 \mathrm{H}), 7.49(\mathrm{~s}, 1 \mathrm{H}), 7.47(\mathrm{~d}, J$ $=8.20 \mathrm{~Hz}, 1 \mathrm{H}), 7.43-7.48(\mathrm{~m}, 1 \mathrm{H}), 7.16(\mathrm{dd}, J=0.95,8.20 \mathrm{~Hz}, 1 \mathrm{H})$, $4.35(\mathrm{td}, J=4.57,9.14 \mathrm{~Hz}, 1 \mathrm{H}), 4.19(\mathrm{dd}, J=2.99,13.71 \mathrm{~Hz}, 1 \mathrm{H})$, $3.96-4.03(\mathrm{~m}, 1 \mathrm{H}), 3.92(\mathrm{dd}, J=10.09,13.56 \mathrm{~Hz}, 1 \mathrm{H}), 3.71-3.75$ $(\mathrm{m}, 1 \mathrm{H}), 3.73(\mathrm{~s}, 2 \mathrm{H}), 3.55(\mathrm{~d}, J=3.15 \mathrm{~Hz}, 2 \mathrm{H}), 2.72-2.85(\mathrm{~m}, 1 \mathrm{H})$, $2.55(\mathrm{~s}, 3 \mathrm{H}), 2.17-2.47(\mathrm{~m}, 8 \mathrm{H}), 2.14(\mathrm{~s}, 3 \mathrm{H}), 1.86-2.03(\mathrm{~m}, 2 \mathrm{H})$, $1.40-1.52(\mathrm{~m}, 1 \mathrm{H}), 0.80(\mathrm{~d}, J=6.62 \mathrm{~Hz}, 3 \mathrm{H}) ;{ }^{13} \mathrm{C} \mathrm{NMR}(125 \mathrm{MHz}$, DMSO- $\left.d_{6}\right) \delta 171.3,157.9,151.7,150.8,150.4,146.2,136.9,133.4$, 130.4, 127.8, 123.5, 118.2, 115.7, 111.8, 109.8, 107.8, 71.3, 62.2, 54.7, 52.5, 49.3, 45.7, 34.1, 28.7, 28.7, 25.5, 24.5, 16.8 .

4-Carboxy-4'-methoxy-[2,3'-bipyridin]-1'-ium Chloride (13d). tert-Butyl-2-bromoisonicotinate $(6.50 \mathrm{~g} ; 25.18 \mathrm{mmol})$, monolithium 4-methoxypyridine-3-boronate $(8.17 \mathrm{~g} ; 50.37 \mathrm{mmol})$, tri-tert-butylphosphonium tetrafluoroborate (731 $\mathrm{mg} ; 2.52 \mathrm{mmol}$ ), and palladium(II) acetate $(565 \mathrm{mg} ; 2.52 \mathrm{mmol})$ were dissolved in $195 \mathrm{~mL}$ of $1,2-$ dimethoxyethane and $65 \mathrm{~mL}$ of water. The mixture was flushed with argon and stirred at room temperature for $5 \mathrm{~min}$. Cesium carbonate (13.95 g; $42.81 \mathrm{mmol})$ then was added, and stirring was continued at $80{ }^{\circ} \mathrm{C}$ for $16 \mathrm{~h}$. The reaction mixture was poured on water and extracted with DCM once. The organic layer was dried over $\mathrm{MgSO}_{4}$ and concentrated under reduced pressure. The residue was purified applying preparative high performance chromatography (method P3). The resulting tert-butyl 2-(4-methoxypyridin-3-yl)pyridine-4-carboxylate $(4.86 \mathrm{~g} ; 16.12 \mathrm{mmol}$ ) was dissolved in $276 \mathrm{~mL}$ of acetonitrile, and $11 \mathrm{~mL}$ of concentrated hydrochloric acid $(131.08 \mathrm{mmol})$ was added. The mixture was stirred at $55{ }^{\circ} \mathrm{C}$ for $16 \mathrm{~h}$. The precipitate was filtered off, washed with cold acetonitrile, and dried in a vacuum to give $4.18 \mathrm{~g}(62 \%, 15.69 \mathrm{mmol})$ of the title compound.

Purity by method A2, 96\%; RT $=0.21 \mathrm{~min}$; MS $\left(\mathrm{ESI}^{+}\right) \mathrm{m} / z 231$ $(\mathrm{M}+\mathrm{H})^{+}$.

(R)-5-((5-Bromo-2-nitrophenyl)amino)-4-methylpentyl Methanesulfonate (15). (R)-5-((5-Bromo-2-nitrophenyl)amino)-4-methylpentan-1-ol $42(20.0 \mathrm{~g}, 63.2 \mathrm{mmol})$ and $\mathrm{Et}_{3} \mathrm{~N}(13.2 \mathrm{~mL}, 94.8 \mathrm{mmol})$ were mixed with $\mathrm{CH}_{2} \mathrm{Cl}_{2}(85 \mathrm{~mL})$, and the resultant solution was cooled to $0{ }^{\circ} \mathrm{C}$. $\mathrm{MsCl}(5.87 \mathrm{~mL}, 75.8 \mathrm{mmol})$ was added dropwise at 0 ${ }^{\circ} \mathrm{C}$, and upon completion of the addition the cooling bath was removed and the reaction mixture was allowed to stir at room temperature for $1 \mathrm{~h}$. The mixture was then washed sequentially with saturated aqueous $\mathrm{NaHCO}_{3}$ solution and water, and the organic phase was dried over $\mathrm{Na}_{2} \mathrm{SO}_{4}$, filtered, and concentrated under reduced pressure to yield the title compound $(24.7 \mathrm{~g}, 62.5 \mathrm{mmol}, 99 \%)$ as an orange oil. HRMS $(m / z):[\mathrm{M}+\mathrm{H}]^{+}$calculated for $\mathrm{C}_{13} \mathrm{H}_{20} \mathrm{BrN}_{2} \mathrm{O}_{5} \mathrm{~S}$, 395.02708; found, 395.02683; ${ }^{1} \mathrm{H}$ NMR (400 MHz, $\left.\mathrm{CDCl}_{3}\right) \delta 8.09$ (br, $1 \mathrm{H}), 7.97(\mathrm{~d}, J=9.07 \mathrm{~Hz}, 1 \mathrm{H}), 6.96(\mathrm{~d}, J=1.98 \mathrm{~Hz}, 1 \mathrm{H}), 6.71$ (dd, $J=1.98,9.08 \mathrm{~Hz}, 1 \mathrm{H}), 4.22(\mathrm{t}, J=6.31 \mathrm{~Hz}, 2 \mathrm{H}), 3.21-3.15(\mathrm{~m}$, $1 \mathrm{H}), 3.11-3.05(\mathrm{~m}, 1 \mathrm{H}), 2.99(\mathrm{~s}, 3 \mathrm{H}), 1.93-1.70(\mathrm{~m}, 3 \mathrm{H}), 1.64-$ $1.55(\mathrm{~m}, 1 \mathrm{H}), 1.41-1.30(\mathrm{~m}, 1 \mathrm{H}), 1.04(\mathrm{~d}, J=6.69 \mathrm{~Hz}, 3 \mathrm{H}) ;{ }^{13} \mathrm{C}$ NMR $\left(100 \mathrm{MHz}, \mathrm{CDCl}_{3}\right) \delta 145.9,131.8,130.8,128.2,118.6,116.4$, 69.8, 49.1, 37.4, 32.3, 30.3, 26.6, 17.8 .

Methyl 2-(5-Hydroxy-1-methyl-1H-pyrazol-4-yl)-6-methylisonicotinate Hydrochloride (16a). Methyl 2-chloro-6-methylisonicotinate 28 (50.0 g, $269.4 \mathrm{mmol}$ ), 1-methyl-1H-pyrazol-5-ol 29 (52.9 g, $538.8 \mathrm{mmol}), \mathrm{PdCl}_{2}(\mathrm{dppf}) \cdot \mathrm{CH}_{2} \mathrm{Cl}_{2}(6.60 \mathrm{~g}, 8.08 \mathrm{mmol})$, powdered $\mathrm{Na}_{2} \mathrm{CO}_{3}(62.8 \mathrm{~g}, 592.7 \mathrm{mmol})$, and anisole $(1000 \mathrm{~mL})$ were heated at $130{ }^{\circ} \mathrm{C}$ under nitrogen for $16 \mathrm{~h}$. The reaction mixture was then cooled to room temperature and was filtered through a $2 \mathrm{~cm}$ pad of Celite. The Celite pad was washed with toluene $(200 \mathrm{~mL})$. The dark filtrate was treated with $\mathrm{MeOH}(150 \mathrm{~mL})$, followed by dropwise addition of $4 \mathrm{M} \mathrm{HCl}$ in dioxane $(100 \mathrm{~mL}, 400 \mathrm{mmol})$. The resultant slurry was stirred at room temperature for $1 \mathrm{~h}$ and then was filtered. The filter cake was washed with toluene and heptane, and was then dried under vacuum at $50{ }^{\circ} \mathrm{C}$ to yield the title compound $(47.5 \mathrm{~g}, 98.4 \mathrm{wt} \%, 164.7$ mmol, $61 \%)$ as a yellow solid. HRMS $(m / z):[\mathrm{M}+\mathrm{H}-\mathrm{HCl}]^{+}$ calculated for $\mathrm{C}_{12} \mathrm{H}_{14} \mathrm{~N}_{3} \mathrm{O}_{3}, 248.10297$; found, 248.10291; ${ }^{1} \mathrm{H}$ NMR $\left(400 \mathrm{MHz}, \mathrm{D}_{2} \mathrm{O}\right) \delta 8.17(\mathrm{~s}, 1 \mathrm{H}), 8.03(\mathrm{~m}, 1 \mathrm{H}), 7.65(\mathrm{~m}, 1 \mathrm{H}), 3.91(\mathrm{~s}$, $3 \mathrm{H}), 3.42(\mathrm{~s}, 3 \mathrm{H}), 2.63(\mathrm{~s}, 3 \mathrm{H}) ;{ }^{13} \mathrm{C}$ NMR $\left(100 \mathrm{MHz}, \mathrm{D}_{2} \mathrm{O}\right) \delta 164.3$, $160.3,151.9,147.9,143.8,132.5,120.1,117.9,95.5,53.9,30.2$, 19.3.

Methyl (R)-2-(5-((5-((5-Bromo-2-nitrophenyl)amino)-4methylpentyl)oxy)-1-methyl-1H-pyrazol-4-yl)-6-methylisonicotinate (17). (R)-5-((5-Bromo-2-nitrophenyl)amino)-4-methylpentyl methanesulfonate $15(13.8 \mathrm{~g}, 95 \%$ purity, $33.1 \mathrm{mmol})$ and methyl 2-(5-hydroxy-1-methyl-1H-pyrazol-4-yl)-6-methylisonicotinate hydrochloride 16a (9.63 g, $33.9 \mathrm{mmol})$ were dissolved in DMF $(50 \mathrm{~mL})$. $\mathrm{K}_{2} \mathrm{CO}_{3}(11.4 \mathrm{~g}, 82.8 \mathrm{mmol})$ then was added, and the mixture was stirred at $60{ }^{\circ} \mathrm{C}$ for $18 \mathrm{~h}$. The reaction mixture was then cooled to room temperature, diluted with methyl tert-butyl ether, and washed twice with water. The organic phase was then dried over $\mathrm{Na}_{2} \mathrm{SO}_{4}$, filtered, and concentrated under reduced pressure to yield the title compound (15.4 g, $28.2 \mathrm{mmol}, 85 \%$ ) as an orange oil. HRMS $(\mathrm{m} / z)$ : $[\mathrm{M}+\mathrm{H}]^{+}$calculated for $\mathrm{C}_{24} \mathrm{H}_{29} \mathrm{BrN}_{5} \mathrm{O}_{5}, 546.13466$; found, 546.13479; ${ }^{1} \mathrm{H}$ NMR (400 MHz, $\mathrm{CDCl}_{3}$ ) $\delta 8.16$ (br m, $\left.1 \mathrm{H}\right), 8.01$ (d, $J=9.12 \mathrm{~Hz}, 1 \mathrm{H}), 7.88(\mathrm{~s}, 1 \mathrm{H}), 7.87-7.86(\mathrm{~m}, 1 \mathrm{H}), 7.48-7.47$ $(\mathrm{m}, 1 \mathrm{H}), 7.00(\mathrm{~d}, J=1.94 \mathrm{~Hz}, 1 \mathrm{H}), 6.73(\mathrm{dd}, J=1.98,9.09 \mathrm{~Hz}, 1 \mathrm{H})$, $4.16(\mathrm{t}, J=6.39 \mathrm{~Hz}, 2 \mathrm{H}), 3.94(\mathrm{~s}, 3 \mathrm{H}), 3.75(\mathrm{~s}, 3 \mathrm{H}), 3.28-3.22(\mathrm{~m}$, $1 \mathrm{H}), 3.16-3.10(\mathrm{~m}, 1 \mathrm{H}), 2.61(\mathrm{~s}, 3 \mathrm{H}), 2.02-1.81(\mathrm{~m}, 3 \mathrm{H}), 1.77-$ $1.69(\mathrm{~m}, 1 \mathrm{H}), 1.53-1.43(\mathrm{~m}, 1 \mathrm{H}), 1.10(\mathrm{~d}, J=6.67 \mathrm{~Hz}, 3 \mathrm{H}) ;{ }^{13} \mathrm{C}$ NMR $\left(100 \mathrm{MHz}, \mathrm{CDCl}_{3}\right) \delta 166.1,159.1,152.2,151.4,145.9,138.0$, $137.9,131.7,130.8,128.2,118.9,118.6,116.3,107.3,74.8,52.6,49.2$, $34.3,32.6,30.8,27.3,24.7,17.8$. 
Methyl (R)-2-(5-((5-((2-Amino-5-bromophenyl)amino)-4methylpentyl)oxy)-1-methyl-1H-pyrazol-4-yl)-6-methylisonicotinate (18). Methyl $(R)-2-(5-((5-((5-b r o m o-2-n i t r o p h e n y l) a m i n o)-4-$ methylpentyl)oxy)-1-methyl-1H-pyrazol-4-yl)-6-methylisonicotinate $17(2.75 \mathrm{~g}, 5.03 \mathrm{mmol})$ and $50 \%$ wet catalyst $1 \% \mathrm{Pt} / 2 \% \mathrm{~V} / \mathrm{C}(2.4 \mathrm{~g}$, $0.015 \mathrm{mmol} \mathrm{Pt}$ ) were added to a $100 \mathrm{~mL}$ hydrogenation autoclave, followed by addition of $\mathrm{MeOH}(40 \mathrm{~mL})$. The reaction mixture was purged with nitrogen three times and then with hydrogen once, followed by hydrogenation under $100 \mathrm{psi}_{2}$ at $20^{\circ} \mathrm{C}$ for $16 \mathrm{~h}$. The reaction mixture was filtered through Celite to remove the catalyst, and then the solvent was removed under reduced pressure to yield the title compound ( $2.54 \mathrm{~g}, 4.92 \mathrm{mmol}, 98 \%)$ as a dark oil. HRMS $(\mathrm{m} / z)$ : $[\mathrm{M}+\mathrm{H}]^{+}$calculated for $\mathrm{C}_{24} \mathrm{H}_{31} \mathrm{BrN}_{5} \mathrm{O}_{3}, 516.16048$; found, 526.16075; ${ }^{1} \mathrm{H}$ NMR $\left(400 \mathrm{MHz}, \mathrm{CDCl}_{3}\right) \delta 7.81(\mathrm{~s}, 2 \mathrm{H}), 7.80(\mathrm{~m}$, $1 \mathrm{H}), 7.41(\mathrm{br} \mathrm{s}, 1 \mathrm{H}), 6.66(\mathrm{dd}, J=2.1,8.1 \mathrm{~Hz}, 1 \mathrm{H}), 6.49(\mathrm{~d}, J=2.1$ $\mathrm{Hz}, 1 \mathrm{H}), 4.06(\mathrm{t}, J=6.4 \mathrm{~Hz}, 1 \mathrm{H}), 3.88(\mathrm{~s}, 3 \mathrm{H}), 3.67(\mathrm{~s}, 3 \mathrm{H}), 3.05(\mathrm{br}$ s, $3 \mathrm{H}), 2.95$ (dd, $J=6.4,12.2 \mathrm{~Hz}, 1 \mathrm{H}), 2.85(\mathrm{dd}, J=6.4,12.0 \mathrm{~Hz}$, $1 \mathrm{H}), 2.54(\mathrm{~s}, 3 \mathrm{H}), 1.76(\mathrm{~m}, 4 \mathrm{H}), 1.34(\mathrm{~m}, 1 \mathrm{H}), 0.97(\mathrm{~d}, J=6.5 \mathrm{~Hz}$, $3 \mathrm{H}) ;{ }^{13} \mathrm{C}$ NMR $\left(100 \mathrm{MHz}, \mathrm{CDCl}_{3}\right) \delta 166.2,159.2,152.2,151.6$, $139.6,138.1,138.0,132.7,120.5,119.0,117.8,116.4,114.0,113.3$, 107.3, 75.1, 52.6, 50.2, 34.3, 32.8, 30.9, 27.4, 24.7, 18.0.

Methyl (R)-2-(5-((5-(2-Amino-6-bromo-1H-benzo[d]imidazol-1yl)-4-methylpentyl)oxy)-1-methyl-1H-pyrazol-4-yl)-6-methylisonicotinate (22a). Methyl (R)-2-(5-((5-((2-amino-5-bromophenyl)amino)-4-methylpentyl)oxy)-1-methyl-1H-pyrazol-4-yl)-6-methylisonicotinate 18 (2.60 g, $5.03 \mathrm{mmol})$ was dissolved in $\mathrm{CH}_{2} \mathrm{Cl}_{2}(25 \mathrm{~mL})$ and tert-butanol $(5 \mathrm{~mL})$. The resultant solution was treated with cyanogen bromide $(0.64 \mathrm{~g}, 6.04 \mathrm{mmol})$, and the reaction mixture was stirred at room temperature for $18 \mathrm{~h}$. The reaction mixture was treated with saturated aqueous $\mathrm{NaHCO}_{3}$ solution and stirred for 10 $\min$. The layers were separated, and the organic phase was washed again with saturated aqueous $\mathrm{NaHCO}_{3}$ solution. The organic phase was then dried over $\mathrm{Na}_{2} \mathrm{SO}_{4}$, filtered, and concentrated under reduced pressure to yield the title compound (2.26 g, $4.17 \mathrm{mmol}, 83 \%)$ as a dark foamy solid. This compound was difficult to purify by chromatography or crystallization and was taken into the next steps directly. HRMS $(m / z):[\mathrm{M}+\mathrm{H}]^{+}$calculated for $\mathrm{C}_{25} \mathrm{H}_{30} \mathrm{BrN}_{6} \mathrm{O}_{3}$, 541.15573; found, 541.15537; ${ }^{1} \mathrm{H}$ NMR $\left(400 \mathrm{MHz}, \mathrm{CDCl}_{3}\right) \delta 7.89-$ $7.87(\mathrm{~m}, 2 \mathrm{H}), 7.47-7.46(\mathrm{~m}, 1 \mathrm{H}), 7.27-7.19(\mathrm{~m}, 3 \mathrm{H}), 4.11-4.06$ $(\mathrm{m}, 2 \mathrm{H}), 3.94(\mathrm{~s}, 3 \mathrm{H}), 3.86-3.81(\mathrm{~m}, 1 \mathrm{H}), 3.75-3.69(\mathrm{~m}, 1 \mathrm{H}), 3.68$ $(\mathrm{s}, 3 \mathrm{H}), 2.60(\mathrm{~s}, 3 \mathrm{H}), 2.19-2.11(\mathrm{~m}, 1 \mathrm{H}), 2.00-1.92(\mathrm{~m}, 1 \mathrm{H}), 1.83-$ $1.66(\mathrm{~m}, 2 \mathrm{H}), 1.48-1.38(\mathrm{~m}, 1 \mathrm{H}), 0.99(\mathrm{~d}, J=6.63 \mathrm{~Hz}, 3 \mathrm{H}) ;{ }^{13} \mathrm{C}$ $\mathrm{NMR}\left(100 \mathrm{MHz}, \mathrm{CDCl}_{3}\right) \delta 166.3,159.3,154.2,152.2,151.4,140.4$, $137.98,137.95,135.6,124.6,119.0,117.3,116.3,112.4,111.1,107.4$, $74.8,52.7,49.2,34.3,33.2,30.7,27.2,24.7,17.4$.

(R)-2-(5-((5-(2-Amino-6-bromo-1H-benzo[d]imidazol-1-yl)-4methylpentyl)oxy)-1-methyl-1H-pyrazol-4-yl)-6-methylisonicotinic Acid (22a'). Methyl (R)-2-(5-((5-(2-amino-6-bromo-1H-benzo[d]imidazol-1-yl)-4-methylpentyl)oxy)-1-methyl-1H-pyrazol-4-yl)-6methylisonicotinate 22a $(1.80 \mathrm{~g}, 3.32 \mathrm{mmol})$ was dissolved in THF $(30 \mathrm{~mL})$. To the reaction mixture was added a solution of $\mathrm{NaOH}$ pellets $(0.53 \mathrm{~g}, 13.3 \mathrm{mmol})$ in water $(30 \mathrm{~mL})$. The reaction mixture was stirred at room temperature for $45 \mathrm{~min}$, and then the THF was removed by distillation under reduced pressure. The solution was acidified with $6 \mathrm{M}$ aqueous $\mathrm{HCl}$ to $\mathrm{pH}=5$, resulting in the formation of a slurry. The solid was filtered and washed with water, and dried under vacuum to yield the title compound ( $1.71 \mathrm{~g}, 3.24 \mathrm{mmol}, 98 \%)$ as a dark solid. HRMS $(\mathrm{m} / z):[\mathrm{M}+\mathrm{H}]^{+}$calculated for $\mathrm{C}_{24} \mathrm{H}_{28} \mathrm{BrN}_{6} \mathrm{O}_{3}$, 527.14008; found, 527.13971; ${ }^{1} \mathrm{H}$ NMR (400 MHz, DMSO-d $\left.d_{6}\right) \delta 7.89-7.84(\mathrm{~m}, 2 \mathrm{H}), 7.70-7.53(\mathrm{~m}, 2 \mathrm{H}), 7.46(\mathrm{~m}, 2 \mathrm{H})$, 7.12 (br s, 2H), 4.07 (br, 2H), 3.98-3.84 (m, 2H), $3.63(\mathrm{~s}, 3 \mathrm{H}), 2.51$ $(\mathrm{s}, 3 \mathrm{H}), 2.12-2.00(\mathrm{~m}, 1 \mathrm{H}), 1.99-1.85(\mathrm{~m}, 1 \mathrm{H}), 1.82-1.67(\mathrm{~m}, 1 \mathrm{H})$, $1.66-1.50(\mathrm{~m}, 1 \mathrm{H}), 1.47-1.29(\mathrm{~m}, 1 \mathrm{H}), 0.83(\mathrm{~d}, J=6.26 \mathrm{~Hz}, 3 \mathrm{H})$; ${ }^{13} \mathrm{C}$ NMR (100 MHz, DMSO- $\left.d_{6}\right) \delta 168.5,158.7,155.0,151.6,151.5$, $142.1,137.6,137.5,135.1,124.4,119.5,116.2,115.3,112.0,111.8$, 107.6, 75.4, 48.0, 34.5, 32.5, 30.1, 27.1, 24.7, 16.7.

(R,E)-11,26,7-Trimethyl-3-oxo-52,53-dihydro-11H,51H-11-oxa-4aza-5(2,1)-benzo[d]imidazola-2(2,4)-pyridina-1 $(4,5)$-pyrazolacycloundecaphane-56-carbaldehyde (27). (R,E)-5 - -Bromo- $1^{1}, 2^{6}, 7$-trimethyl- $5^{2}, 5^{3}$-dihydro- $11 H, 51 H$-11-oxa-4-aza-5(2,1)-benzo[d]imidazola-2(2,4)-pyridina-1 (4,5)-pyrazolacycloundecaphan-3-one
$9 \mathrm{Br}(2.27 \mathrm{~g}, 4.46 \mathrm{mmol}), \mathrm{Pd}(\mathrm{OAc})_{2}(50.0 \mathrm{mg}, 0.223 \mathrm{mmol}), \mathrm{di}(1-$ adamantyl)- $n$-butylphosphine $(240 \mathrm{mg}, 0.668 \mathrm{mmol})$, dioxane (34 $\mathrm{mL}$ ), and TMEDA (1.34 mL, $8.91 \mathrm{mmol}$ ) were charged to a HEL reactor under nitrogen. The reaction mixture was heated to $100{ }^{\circ} \mathrm{C}$ for $24 \mathrm{~h}$ under $80 \mathrm{psi}$ of $\mathrm{CO} / \mathrm{H}_{2}$ syngas. After being cooled to room temperature, the reaction was filtered through a filter paper to remove precipitates, and the filtrate was concentrated under reduced pressure. The crude residue was purified by flash chromatography on $\mathrm{SiO}_{2}$ using an elution gradient of $0-4 \% \mathrm{MeOH}$ in $\mathrm{CH}_{2} \mathrm{Cl}_{2}$. The title compound was obtained as a white solid $(2.00 \mathrm{~g}, 3.80 \mathrm{mmol}, 85 \%)$. HRMS $(m / z):[\mathrm{M}+\mathrm{H}]^{+}$calculated for $\mathrm{C}_{25} \mathrm{H}_{27} \mathrm{~N}_{6} \mathrm{O}_{3}, 459.21392$; found, 459.21363; ${ }^{1} \mathrm{H}$ NMR (400 MHz, $\left.\mathrm{CDCl}_{3}\right) \delta 12.27$ (br s, $\left.1 \mathrm{H}\right)$, $10.04(\mathrm{~s}, 1 \mathrm{H}), 8.47(\mathrm{~s}, 1 \mathrm{H}), 8.16(\mathrm{~s}, 1 \mathrm{H}), 7.83(\mathrm{~d}, J=0.9 \mathrm{~Hz}, 1 \mathrm{H})$, $7.77(\mathrm{dd}, J=8.1,1.3 \mathrm{~Hz}, 1 \mathrm{H}), 7.64(\mathrm{~d}, J=0.9 \mathrm{~Hz}, 1 \mathrm{H}), 7.47(\mathrm{~d}, J=$ $8.1 \mathrm{~Hz}, 1 \mathrm{H}), 4.45(\mathrm{~m}, 1 \mathrm{H}), 4.38(\mathrm{~m}, 1 \mathrm{H}), 3.89(\mathrm{~m}, 1 \mathrm{H}), 3.78$ (two overlapping peaks, $4 \mathrm{H}), 2.86(\mathrm{~m}, 1 \mathrm{H}), 2.63(\mathrm{~s}, 3 \mathrm{H}), 2.28(\mathrm{~m}, 1 \mathrm{H}), 2.1$ $(\mathrm{m}, 1 \mathrm{H}), 1.98(\mathrm{~m}, 1 \mathrm{H}), 1.55(\mathrm{~m}, 1 \mathrm{H}), 0.93(\mathrm{~d}, J=6.6 \mathrm{~Hz}, 3 \mathrm{H}) ;{ }^{13} \mathrm{C}$ NMR $\left(100 \mathrm{MHz}, \mathrm{CDCl}_{3}\right) \delta 191.0,175.2,159.0,154.4,151.3,151.2$, $145.3,138.4,133.2,132.5,131.5,127.3,118.8,116.8,111.5,108.9$, 71.3, 50.6, 34.3, 29.61, 29.59, 26.4, 24.9, 17.7 .

(R)-5-((5-Bromo-2-nitrophenyl)amino)-4-methylpentan-1-ol (42). 4-Bromo-2-fluoro-1-nitrobenzene 41 (14.0 g, $63.6 \mathrm{mmol}),(R)$ 5-amino-4-methylpentan-1-ol hydrochloride 43 (10.5 g, 97.7 wt \%, $66.8 \mathrm{mmol})$, and $\mathrm{K}_{2} \mathrm{CO}_{3}(19.3 \mathrm{~g}, 140.0 \mathrm{mmol})$ were stirred in DMF $(42 \mathrm{~mL})$ for $24 \mathrm{~h}$ at room temperature. The reaction mixture was then diluted with water and extracted with methyl tert-butyl ether. The organic phase was dried over $\mathrm{Na}_{2} \mathrm{SO}_{4}$, filtered, and concentrated under reduced pressure to yield the title compound $(20.0 \mathrm{~g}, 63.2$ mmol, 99\%) as an orange oil. HRMS $(\mathrm{m} / z):[\mathrm{M}+\mathrm{H}]^{+}$calculated for $\mathrm{C}_{12} \mathrm{H}_{18} \mathrm{BrN}_{2} \mathrm{O}_{3}, 317.04953$; found, 317.04942; ${ }^{1} \mathrm{H}$ NMR (400 MHz, $\left.\mathrm{CDCl}_{3}\right) \delta 8.10(\mathrm{br}, 1 \mathrm{H}), 7.96(\mathrm{~d}, J=9.14 \mathrm{~Hz}, 1 \mathrm{H}), 6.95(\mathrm{~d}, J=1.98$ $\mathrm{Hz}, 1 \mathrm{H}), 6.68(\mathrm{dd}, J=1.95,9.08 \mathrm{~Hz}, 1 \mathrm{H}), 3.63(\mathrm{t}, J=6.39 \mathrm{~Hz}, 2 \mathrm{H})$, 3.21-3.15 (m, 1H), 3.08-3.02 (m, 1H), $2.04(\mathrm{~s}, 1 \mathrm{H}), 1.91-1.83(\mathrm{~m}$, $1 \mathrm{H}), 1.71-1.48(\mathrm{~m}, 3 \mathrm{H}), 1.35-1.26(\mathrm{~m}, 1 \mathrm{H}), 1.03(\mathrm{~d}, J=6.74 \mathrm{~Hz}$, $3 \mathrm{H}) ;{ }^{13} \mathrm{C}$ NMR $\left(100 \mathrm{MHz}, \mathrm{CDCl}_{3}\right) \delta 146.0,131.8,130.7,128.1$, 118.5, 116.4, 62.8, 49.2, 32.5, 30.7, 29.9, 18.0.

Protein Production, Crystallization, and Structure Determination. An EGFR kinase construct comprising amino acids 696-1022 was expressed as a GST-fusion protein in insect cells. In addition to the mutations T790M, L858R, the construct also contained three mutations to improve crystallization with "EEK" (865-867) mutated to "AAA" as described by Hanan et al., 2004. ${ }^{61}$ Protein was purified by a three-step procedure using a $20 \mathrm{~mL}$ GSTrap-column (GE Health Care), followed by tag-cleavage with thrombin, a second passage over the GSTrap column, and a final gel filtration step on a Superdex75 26/60 column (GE Health Care). Pure and monomeric protein was pooled, buffer exchanged into $25 \mathrm{mM}$ TRIS $/ \mathrm{HCl}, \mathrm{pH}=8.0,100 \mathrm{mM}$ $\mathrm{NaCl}, 2 \mathrm{mM}$ DTT, $2 \mathrm{mM}$ TCEP, concentrated to $11 \mathrm{mg} / \mathrm{mL}$, and stored in aliquots at $-80{ }^{\circ} \mathrm{C}$ until crystallization.

For crystallization, the protein was diluted to $8 \mathrm{mg} / \mathrm{mL}$. Crystals were grown at $20{ }^{\circ} \mathrm{C}$ from $10 \%$ PEG10000, $8 \%$ ethylene glycol, 0.10 M HEPES pH 7.5 by hanging drop method. For crystallization, $1 \mu \mathrm{L}$ of the protein solution was mixed with $0.5 \mu \mathrm{L}$ of the reservoir solution and placed over $300 \mu \mathrm{L}$ of the reservoir solution in 15-well plates (Qiagen). Ligand complexes were generated by soaking apo crystals with $5 \mathrm{mM}$ of the respective ligand for $3 \mathrm{~h}$. For cryo protection, crystals were briefly immersed in a reservoir solution containing $20 \%$ $(\mathrm{v} / \mathrm{v}) \mathrm{L}-(+)-2,3-$ butanediol and frozen in liquid nitrogen.

Diffraction data were measured at $100 \mathrm{~K}$ at the Swiss Light Source (beamline PXI/X06SA). Data were integrated with XDS and scaled with XSCALE. ${ }^{62}$ Molecular replacement was performed with MOLREP. ${ }^{63}$ The structures were refined with REFMAC. ${ }^{64}$

Protein crystallography has been done by Proteros Biostructures (Martinsried). Coordinates and structure factors have been deposited at the PDB with PDB codes 6S9B (compound 1), 6S9C (compound 5), and 6S9D (compound 6).

Biochemical EGFR Inhibition Assays. These assays measure the inhibitory effect of compounds on the phosphorylation activity of EGFR enzyme forms on poly-GT substrate in the presence of ATP. 
The following enzyme forms of EGFR have been used in these assays at the given concentrations: EGFR WT (Life Technologies; PV4190), final assay concentration $1.5 \mathrm{nM}$; and EGFR (d746-750 T790M C797S) (SignalChem; E10-12UG), final assay concentration $15 \mathrm{nM}$.

Test compounds dissolved in DMSO were dispensed onto assay plates (Proxiplate 384 PLUS, white, PerkinElmer; 6008289) using an Access Labcyte Workstation with the Labcyte Echo 55x. For the chosen highest assay concentration of $100 \mu \mathrm{M}, 150 \mathrm{~nL}$ of compound solution was transferred from a $10 \mathrm{mM}$ DMSO compound stock solution. A series of 115 -fold dilutions per compound was transferred to the assay plate, and compound dilutions were tested in duplicates. DMSO was added as backfill to a total volume of $150 \mathrm{~nL}$. The assay runs on a fully automated robotic system.

$5 \mu \mathrm{L}$ of EGFR enzyme form in assay buffer ( $50 \mathrm{mM}$ HEPES $\mathrm{pH}$ 7.3, $10 \mathrm{mM} \mathrm{MgCl}_{2}, 1 \mathrm{mM}$ EGTA, 0.01\% Tween 20, $2 \mathrm{mM} \mathrm{DTT)} \mathrm{was}$ dispensed into columns $1-23$, and then $5 \mu \mathrm{L}$ of ATP and ULightpoly-GT substrate (PertkinElmer; TRF0100-M) mixed in assay buffer was added to all wells (final assay concentration of ATP $100 \mu \mathrm{M}$ and ULight-poly-GT substrate $200 \mathrm{nM}$ ).

After 90 min incubation at room temperature, $5 \mu \mathrm{L}$ of EDTA (final assay concentration $50 \mathrm{mM}$ ) and LANCE Eu-anti-P-Tyr (PT66) antibody (PerkinElmer, AD0069) (final assay concentration $6 \mathrm{nM}$ ) mix were added to stop the reaction and start the binding of the antibody.

After an additional $60 \mathrm{~min}$ incubation at room temperature, the signal was measured in a PerkinElmer Envision HTS Multilabel Reader using the TR-FRET LANCE Ultra specs of PerkinElmer (used wavelengths: excitation $320 \mathrm{~nm}$, emission1 $665 \mathrm{~nm}$, emission2 615 $\mathrm{nm})$.

Each plate contains 16 wells of a negative control (diluted DMSO instead of test compound; with EGFR enzyme form; column 23) and 16 wells of a positive control (diluted DMSO instead of test compound; without EGFR enzyme form; column 24).

Negative and positive control values were used for normalization, and $\mathrm{IC}_{50}$ values were calculated and analyzed using a 4 parametric logistic model.

These biochemical EGFR enzyme form compound dose-response assays quantify the kinase activity via phosphorylation of a tagged poly-GT substrate. The results of the assay are provided as $\mathrm{IC}_{50}$ values. The lower were the reported biochemical EGFR enzyme form $\mathrm{IC}_{50}$ values for a given compound, the more potent the compound inhibits the EGFR enzyme form kinase activity on poly-GT substrate.

$\mathrm{Ba} / \mathrm{F} 3$ Proliferation Data. Ba/F3 cells (purchased from DSMZ, cat. no. ACC300) were grown in RPMI-1640 medium supplemented with $10 \% \mathrm{FCS}$ at $37^{\circ} \mathrm{C}$ in $5 \% \mathrm{CO}_{2}$ atmosphere in the presence of 10 $\mathrm{ng} / \mathrm{mL}$ IL-3 (purchased from R\&D). To generate Ba/F3 EGFR models, $\mathrm{Ba} / \mathrm{F} 3$ cells were transduced with retroviruses encoding the Green Fluorescent Protein (GFP) and EGFR isoforms EGFRwt, EGFRdel19, or EGFRdel19 TM CS. Platinum-E cells (Cell Biolabs) were used for retrovirus packaging. $\mathrm{Ba} / \mathrm{F} 3$ cells were transduced with a retrovirus encoding only GFP to generate EGFR-independent $\mathrm{Ba}$ / F3 cells. Retrovirus and $4 \mu \mathrm{g} / \mathrm{mL}$ Polybrene was added to Ba/F3 cells for spinfection. Infection efficiency was confirmed by measuring GFPpositive cells using a cell analyzer. Cells with an infection efficiency of $10-20 \%$ were further cultivated in the presence of Puromycin $(1 \mu \mathrm{g} /$ $\mathrm{mL}$ ) to select for transduced cells. Following selection, IL-3 was withdrawn from transgenic $\mathrm{Ba} / \mathrm{F} 3$ cells expressing the oncogenic EGFR alleles EGFRdel19 and EGFRdel19 TM CS to render the growth of the cells dependent on transgenic EGFR activity. At IL-3 withdrawal EGF ligand (conc., source) was added to cells expressing EGFRwt, which are dependent on ligand stimulation in the absence of IL-3. Empty vector-transduced cells were maintained in medium containing IL-3 to generate EGFR-independent control cells. For proliferation assays, $\mathrm{BaF} / 3$ cells were seeded into a 96 -well plates at 5 $\times 103 / 100 \mu \mathrm{L}$ in growth media. Compounds were added by using a HP D3000 Digital Dispenser. All treatments were performed in technical and biological triplicates. Treated cells were incubated for 72 $\mathrm{h}$ at $37{ }^{\circ} \mathrm{C}$ with $5 \% \mathrm{CO}_{2}$. CellTiter-Glo Luminescent Cell Viability Assay (Promega) was performed, and chemoluminescence was measured by using the multilabel Plate Reader VICTOR X4. The raw data were imported into and analyzed with the Boehringer Ingelheim proprietary software MegaLab (curve fitting based on the program PRISM, GraphPad Inc.).

Ba/F3 p-EGFR Biomarker Assay. 60.000 Ba/F3 EGFRdel19 TM CS expressing cells were seeded in $60 \mu \mathrm{L}$ of DMEM with $10 \%$ FBS per well into a TC 384-well plate (Greiner 781182). $60 \mathrm{~nL}$ of compound solution was added with the Echo Access System (Labcyte). All treatments were done in technical and biological duplicates. Treated cells were incubated for $4 \mathrm{~h}$ at $37{ }^{\circ} \mathrm{C}$ with $5 \%$ $\mathrm{CO}_{2}$. Plates were then centrifuged for $10 \mathrm{~min}$, and medium was removed by the EL406 Washer and replaced by $20 \mu \mathrm{L}$ of a 1.6 -fold lysis buffer of the p-EGF Receptor (p-Tyr1068) TGRERS kit (PerkinElmer). After incubation at rt with agitation on a plate shaker (700 rpm) for $20 \mathrm{~min}$, plates were centrifuged for $5 \mathrm{~min}$, and $4 \mu \mathrm{L}$ of the lysate was transferred to a Proxiplate-384 Plus (PerkinElmer). Five microliters of Acceptor Mix (reaction buffer + activation buffer + AlphaScreen Acceptor beads, PerkinElmer) was added, and plates were shaken for $1 \mathrm{~min}(14000 \mathrm{rpm})$ and incubated for $2 \mathrm{~h}$ at room temperature under subdued light. Three microliters of Donor Mix (dilution buffer + AlphaScreen Donor beads, PerkinElmer 6760002) were added per well, and plates were shaken for $1 \mathrm{~min}$. After $2 \mathrm{~h}$ at rt, plates were read on an Envision2 (PerkinElmer) using standard 384 AlphaScreen settings. The raw data were imported into and analyzed with the Boehringer Ingelheim proprietary software MegaLab (curve fitting based on the program PRISM, GraphPad Inc.).

Proliferation Assays with A431 and PC-9del19 T790M C7975 Cells. A431 cells were obtained from ATCC (CRL-1555 lot no. 1179038) and cultured in DMEM containing 10\% FBS and supplemented with sodium pyruvate. Parental PC-9 cells were purchased from ECACC (90071810 lot no. 14A030) and cultured in RPMI (Gibco 61870) containing 10\% FBS. Genome engineering was used to insert the mutations T790M and C797S into exon 20 of the endogenous EGFR locus, resulting in the isolation of the PC-9 $9^{\text {del19 }}$ T790M C797S variant. Successful introduction of the two mutations was verified using DNA sequencing, RNA sequencing, and dose-response treatments with EGFR TKI.

5000 A431 cells and 2000 PC-9 $9^{\text {del19 }}$ T790M C797s cells were plated per well in a 96-well plate. Twenty-four hours after plating, cells were treated with compounds. All treatments were performed in technical and biological triplicates. Treated cells were incubated for $96 \mathrm{~h}$ at 37 ${ }^{\circ} \mathrm{C}$ with $5 \% \mathrm{CO}_{2}$. CellTiter-Glo Luminescent Cell Viability Assay (Promega, \#G7572) was performed, and luminescence signalsS were detected by using the multilabel Plate Reader VICTOR X4. Quantifications of viable cells were calculated by normalization of compound treated cells to DMSO treated cells. $\mathrm{IC}_{50}$ values were calculated using Megalab Software (Boehringer Ingelheim).

In Vivo Studies in Mice. Mice were group-housed (8-10 mice per cage) under pathogen-free and controlled environmental conditions $\left(21 \pm 1.5{ }^{\circ} \mathrm{C}\right.$ temperature, $55 \pm 10 \%$ humidity $)$ and handled according to the institutional, governmental, and European Union guidelines (Austrian Animal Protection Laws, GV-SOLAS, and FELASA guidelines). Animal studies were approved by the internal ethics committee and the local governmental committee. For the biomarker and xenograft studies, $6-8$ week old females BomTac:NMRI-Foxn $1^{n u}$ mice; Taconic, Denmark) were engrafted subcutaneously with $5 \times 10^{6} \mathrm{PC}-9^{\text {del19 T790M C797S }}$ cells. Animals were randomized according to tumor size 7 days after cell injection $(N=8 /$ group for compound and $N=10$ for vehicle treated mice). Animals were treated daily with $25 \mathrm{mg} / \mathrm{kg}$ osimertinib, $10 \mathrm{mg} / \mathrm{kg}$ BI-4020, or with the vehicle (Natrosol $0.5 \%$ ) only. Tumor size and body weight were measured three times weekly. Animals were examined daily and sacrificed on the basis of severity criteria including tumor size exceeding $1500 \mathrm{~mm}^{3}$ or tumor necrosis. For the biomarker experiment, animals were randomized 17 days after cell injection $(N=4)$ and once treated 1 day later with $10 \mathrm{mg} / \mathrm{kg} \mathrm{BI-4020}$ or with the vehicle only. Tumor samples were harvested 6, 18, and $24 \mathrm{~h}$ later and frozen in liquid nitrogen for analysis.

One-sided decreasing Mann-Whitney tests were used to compare tumor volumes. The $p$ values were adjusted for multiple comparisons 
according to Bonferroni-Holm. For all analysis, $p$ values under 0.05 represented a statistically significant effect.

In Vivo $p$-EGFR Biomarker Experiments. Proteins from PC$9^{\text {del19 T790M C797S }}$ tumor samples were extracted using ReadyPrep Mini Grinders (BioRad, \#1632146). Tumor tissue was disrupted with a pestle in Tris Lysis Buffer (MSD, \#R60TX-2) supplemented with Halt Protease and Phosphatase Inhibitor Cocktail (100X) (Thermo Scientific, \#78446). After $10 \mathrm{~min}$ of incubation on ice, samples were centrifuged at $13000 \mathrm{rpm}$ for $5 \mathrm{~min}$ at $4{ }^{\circ} \mathrm{C}$. Supernatant was shock frozen in LN2 and stored at $-80{ }^{\circ} \mathrm{C}$ overnight. Protein concentrations were determined using Bradford assay. For Wes Protein Simple analysis, $0.5 \mu \mathrm{g}$ of total protein was analyzed using EGFR, p-EGFR, and GAPDH antibodies (EGF Receptor (D38B1) XP Rabbit mAb \#4267; Phospho-EGF Receptor (Tyr1068) (D7A5) XP Rabbit mAb \#3777, Cell Signaling Technology) (Anti-GAPDH antibody - Loading Control (ab9485), abam). Protein levels were quantified using Wes Protein Simple Compass Software.

DMPK Assays. Aqueous solubility was determined from $1 \mathrm{mg} / \mathrm{mL}$ solid compound dispensed into aqueous Mcllvaine buffer ( $\mathrm{pH} 4.5$ or 6.8), or dissolved in acetonitrile/water (1:1) as reference. Dissolved concentrations were determined with an Agilent 1200 HPLC/DADUV system.

Plasma protein binding (PPB) was determined by equilibrium dialysis. Plasma was spiked with EGFR TKI and dialyzed against Soerensen buffer ( $\mathrm{pH}$ 7.4) for $3 \mathrm{~h}$ at $37{ }^{\circ} \mathrm{C}$. PPB was calculated by quantifying EGFR TKI concentrations in plasma and buffer by HPLC/MS-MS. In vivo hepatic clearance (CL) was predicted by in vitro incubations of $1 \mu \mathrm{M}$ EGFR TKI with cryopreserved hepatocytes (Celsis IVT) and measured depletion over $240 \mathrm{~min}$ by quantitation of EGFR TKI by LC/MS/MS and using the well-stirred model. Data for hepatic $\mathrm{CL}$ were reported as $\% \mathrm{QH}$ values. $\% \mathrm{QH}$ values were determined by normalizing the hepatic CL by the respective blood follow through the liver (e.g., $90 \mathrm{~mL} / \mathrm{min} / \mathrm{kg}$ for mouse, $20.7 \mathrm{~mL} /$ $\mathrm{min} / \mathrm{kg}$ for human). For BI-4020, the predicted CL by human hepatocytes is $9.7 \mathrm{~mL} / \mathrm{min} / \mathrm{kg}$. This corresponds to a clearance of $(9.7 \mathrm{~mL} / \mathrm{min} / \mathrm{kg} / 20.7 \mathrm{~mL} / \mathrm{min} / \mathrm{kg}=0.47) 47 \% \mathrm{QH}$.

PAMPA parameters were determined by using a chamber separated by a microfilter disc (coated with structured layers of immobilized artificial phospholipid membranes) into a donor and an acceptor area. The time-dependent compound concentrations between the two champers are measured by LC/MS and compared to the concentration in the donor compartment prior to incubation. From this information, the permeability coefficient through the artificial membrane is calculated. ${ }^{65}$

For mouse pharmacokinetics (PK) analysis, NMRI mice $(n=3$ per group) were dosed with BI-4042 orally $(10 \mathrm{mg} / \mathrm{kg})$ or intravenously $(1 \mathrm{mg} / \mathrm{kg})$. Five plasma samples were obtained per mouse at defined time points. After precipitation of the plasma protein with acetonitrile, the concentrations of BI-4020 were measured using LC-MS/MS against a calibration curve to calculate the concentration in plasma. The obtained concentration-time profiles are displayed in Figure S4.

\section{ASSOCIATED CONTENT}

\section{S Supporting Information}

The Supporting Information is available free of charge on the ACS Publications website at DOI: 10.1021/acs.jmedchem.9b01169.

Details for the QM-calculation for Figure 4; description of the analytic and preparative HPLC methods as well as synthesis and analytic data (RT, MS, HRMS, and ${ }^{1} \mathrm{H}$ NMR) of compounds 13a, 13e, 16b, 16c, 20a, 20b, 22b, 22c, 24, 25a, 25, 26, 34, 35, 35a, 36, 37, 39, 40, 43, and 44; X-ray data collection and refinement statistics for compounds 1, 5, 6, and $9 \mathrm{Br}$; HPLC-traces for compounds 1, 2, 3, 3a, 4, 5, 6, 7, 8, 9, 9Br, and BI4020; list of kinases of the kinase selectivity panels; and biochemical data for 6-BI-4020 and PK graphs of BI4020 (PDF)
Molecular-formula strings (CSV)

\section{Accession Codes}

Coordinates and structure factors have been deposited at the $\mathrm{PDB} / \mathrm{CCDC}$ with $\mathrm{PDB} / \mathrm{CCDC}$ codes $6 \mathrm{~S} 9 \mathrm{~B}$ (compound 1), 6S9C (compound 5), 6S9D (compound 6), and 1941612 (compound 9Br). We will release coordinates and experimental data upon publication.

\section{AUTHOR INFORMATION}

\section{Corresponding Author}

*E-mail: harald.engelhardt@boehringer-ingelheim.com.

ORCID $\odot$

Harald Engelhardt: 0000-0001-8170-1893

Eugene Chong: 0000-0002-5038-0131

Peter Ettmayer: 0000-0002-8422-2625

Nina Gonnella: 0000-0001-8944-7180

Nitinchandra D. Patel: 0000-0001-9571-6658

Jonathan T. Reeves: 0000-0002-3051-3304

\section{Present Address}

${ }^{\S}$ Merck Healthcare KGaA, Frankfurter Strasse 250, Darmstadt 64293, Germany.

\section{Author Contributions}

${ }$ H.E. and D.B. contributed equally.

\section{Notes}

The authors declare no competing financial interest.

\section{ACKNOWLEDGMENTS}

We would like to thank Amy Gao, Gabriele Glendinning, Christoph Harrer, Susanne Mayer, Julia Mosler, Scott Pennino, Christian Salamon, Markus Spina, Elisabeth Traxler, June Wang, and Anika Weiss for excellent project support. This work was supported by the Austrian Research Promotion Agency (FFG) [grant number 872827].

\section{ABBREVIATIONS USED}

HATU, 1-[bis(dimethylamino)methylene]-1H-1,2,3-triazolo$[4,5-b]$ pyridinium 3-oxid hexafluorophosphate

\section{REFERENCES}

(1) Roskoski, R. J. There are 49 FDA-Approved Small Molecule Protein Kinase Inhibitors as of 12 April 2019. http://www.brimr.org/ PKI/PKIs.htm (accessed May 3, 2019).

(2) Smyth, L. A.; Collins, I. Measuring and Interpreting the Selectivity of Protein Kinase Inhibitors. Journal of chemical biology 2009, 2 (3), 131-151.

(3) Anastassiadis, T.; Deacon, S. W.; Devarajan, K.; Ma, H.; Peterson, J. R. Comprehensive Assay of Kinase Catalytic Activity Reveals Features of Kinase Inhibitor Selectivity. Nat. Biotechnol. 2011, 29 (11), 1039.

(4) Tang, Z. H.; Lu, J. J. Osimertinib Resistance in Non-Small Cell Lung Cancer: Mechanisms and Therapeutic Strategies. Cancer Lett. 2018, 420, 242-246.

(5) Ricordel, C.; Friboulet, L.; Facchinetti, F.; Soria, J. C. Molecular Mechanisms of Acquired Resistance to Third-Generation EGFR-TKIs in EGFR T790M-Mutant Lung Cancer. Annals of Oncology 2018, 29, No. i28-i37.

(6) Lategahn, J.; Keul, M.; Rauh, D. Lessons to be Learned: The Molecular Basis of Kinase-Targeted Therapies and Drug Resistance in Non-Small Cell Lung Cancer. Angew. Chem., Int. Ed. 2018, 57 (9), 2307-2313.

(7) Zhu, S. J.; Zhao, P.; Yang, J.; Ma, R.; Yan, X. E.; Yang, S. Y.; Yang, J. W.; Yun, C. H. Structural Insights into Drug Development 
Strategy Targeting EGFR T790M/C797S. Oncotarget 2018, 9 (17), 13652-13665.

(8) Elkins, J. M.; Fedele, V.; Szklarz, M.; Abdul Azeez, K. R.; Salah, E.; Mikolajczyk, J.; Romanov, S.; Sepetov, N.; Huang, X.-P.; Roth, B. L.; Al Haj Zen, A.; Fourches, D.; Muratov, E.; Tropsha, A.; Morris, J.; Teicher, B. A.; Kunkel, M.; Polley, E.; Lackey, K. E.; Atkinson, F. L.; Overington, J. P.; Bamborough, P.; Muller, S.; Price, D. J.; Willson, T. M.; Drewry, D. H.; Knapp, S.; Zuercher, W. J. Comprehensive Characterization of the Published Kinase Inhibitor Set. Nat. Biotechnol. 2016, 34 (1), 95-103.

(9) Drewry, D. H.; Wells, C. I.; Andrews, D. M.; Angell, R.; Al-Ali, H.; Axtman, A. D.; Capuzzi, S. J.; Elkins, J. M.; Ettmayer, P.; Frederiksen, M.; Gileadi, O.; Gray, N.; Hooper, A.; Knapp, S.; Laufer, S.; Luecking, U.; Mueller, S.; Muratov, E.; Denny, R. A.; Saikatendu, K. S.; Treiber, D. K.; Zuercher, W. J.; Willson, T. M. Progress Towards a Public Chemogenomic Set for Protein Kinases and a Call for Contributions. PLoS One 2017, 12, 1-21.

(10) Driggers, E. M.; Hale, S. P.; Lee, J.; Terrett, N. K. The Exploration of Macrocycles for Drug Discovery - An Underexploited Structural Class. Nat. Rev. Drug Discovery 2008, 7 (7), 608-624.

(11) Johnson, T. W.; Richardson, P. F.; Bailey, S.; Brooun, A.; Burke, B. J.; Collins, M. R.; Cui, J. J.; Deal, J. G.; Deng, Y.-L.; Dinh, D.; Engstrom, L. D.; He, M.; Hoffman, J.; Hoffman, R. L.; Huang, Q.; Kania, R. S.; Kath, J. C.; Lam, H.; Lam, J. L.; Le, P. T.; Lingardo, L.; Liu, W.; McTigue, M.; Palmer, C. L.; Sach, N. W.; Smeal, T.; Smith, G. L.; Stewart, A. E.; Timofeevski, S.; Zhu, H.; Zhu, J.; Zou, H. Y.; Edwards, M. P. Discovery of (10R)-7-Amino-12-fluoro-2,10,16trimethyl-15-oxo-10,15,16,17-tetrahydro-2H-8,4-(metheno)pyrazolo$[4,3-\mathrm{h}][2,5,11]$-benzoxadiazacyclotetradecine-3-carbonitrile (PF06463922), a Macrocyclic Inhibitor of Anaplastic Lymphoma Kinase (ALK) and c-ros Oncogene 1 (ROS1) with Preclinical Brain Exposure and Broad-Spectrum Potency against ALK-Resistant Mutations. J. Med. Chem. 2014, 57 (11), 4720-4744.

(12) Midha, A.; Dearden, S.; McCormack, R. EGFR Mutation Incidence in Non-Small-Cell Lung Cancer of Adenocarcinoma Histology: a Systematic Review and Global Map by Ethnicity (mutMapII). Am. J. Cancer Res. 2015, 5, 2892-2911.

(13) Konduri, K.; Gallant, J.-N.; Chae, Y. K.; Giles, F. J.; Gitlitz, B. J.; Gowen, K.; Ichihara, E.; Owonikoko, T. K.; Peddareddigari, V.; Ramalingam, S. S.; Reddy, S. K.; Eaby-Sandy, B.; Vavala, T.; Whiteley, A.; Chen, H.; Yan, Y.; Sheehan, J. H.; Meiler, J.; Morosini, D.; Ross, J. S.; Stephens, P. J.; Miller, V. A.; Ali, S. M.; Lovly, C. M. EGFR Fusions as Novel Therapeutic Targets in Lung Cancer. Cancer Discovery 2016, 6 (6), 601-611.

(14) Mitsudomi, T.; Morita, S.; Yatabe, Y.; Negoro, S.; Okamoto, I.; Tsurutani, J.; Seto, T.; Satouchi, M.; Tada, H.; Hirashima, T.; Asami, K.; Katakami, N.; Takada, M.; Yoshioka, H.; Shibata, K.; Kudoh, S.; Shimizu, E.; Saito, H.; Toyooka, S.; Nakagawa, K.; Fukuoka, M. Gefitinib Versus Cisplatin Plus Docetaxel in Patients With NonSmall-Cell Lung Cancer Harboring Mutations of the Epidermal Growth Factor Receptor (WJTOG3405): an Open Label, Randomised Phase 3 trial. Lancet Oncol. 2010, 11 (2), 121-128.

(15) Park, K.; Tan, E.-H.; O’Byrne, K.; Zhang, L.; Boyer, M.; Mok, T.; Hirsh, V.; Yang, J. C.-H.; Lee, K. H.; Lu, S.; Shi, Y.; Kim, S.-W.; Laskin, J.; Kim, D.-W.; Arvis, C. D.; Kolbeck, K.; Laurie, S. A.; Tsai, C.-M.; Shahidi, M.; Kim, M.; Massey, D.; Zazulina, V.; Paz-Ares, L. Afatinib Versus Gefitinib as First-Line Treatment of Patients with EGFR Mutation-Positive Non-Small-Cell Lung Cancer (LUX-Lung 7): a Phase 2B, Open-Label, Randomised Controlled Trial. Lancet Oncol. 2016, 17 (5), 577-589.

(16) Soria, J. C.; Ohe, Y.; Vansteenkiste, J.; Reungwetwattana, T.; Chewaskulyong, B.; Lee, K. H.; Dechaphunkul, A.; Imamura, F.; Nogami, N.; Kurata, T.; Okamoto, I.; Zhou, C.; Cho, B. C.; Cheng, Y.; Cho, E. K.; Voon, P. J.; Planchard, D.; Su, W. C.; Gray, J. E.; Lee, S. M.; Hodge, R.; Marotti, M.; Rukazenkov, Y.; Ramalingam, S. S. Osimertinib in Untreated EGFR-Mutated Advanced Non-Small-Cell Lung Cancer. N. Engl. J. Med. 2018, 378 (2), 113-125.

(17) Zhou, C.; Wu, Y.-L.; Chen, G.; Feng, J.; Liu, X.-Q.; Wang, C.; Zhang, S.; Wang, J.; Zhou, S.; Ren, S.; Lu, S.; Zhang, L.; Hu, C.; Hu,
C.; Luo, Y.; Chen, L.; Ye, M.; Huang, J.; Zhi, X.; Zhang, Y.; Xiu, Q.; Ma, J.; Zhang, L.; You, C. Erlotinib Versus Chemotherapy as FirstLine Treatment for Patients with Advanced EGFR Mutation-Positive Non-Small-Cell Lung Cancer (OPTIMAL, CTONG-0802): a Multicentre, Open-Label, Randomised, Phase 3 Study. Lancet Oncol. 2011, 12 (8), 735-742.

(18) Wu, Y.-L.; Cheng, Y.; Zhou, X.; Lee, K. H.; Nakagawa, K.; Niho, S.; Tsuji, F.; Linke, R.; Rosell, R.; Corral, J.; Migliorino, M. R.; Pluzanski, A.; Sbar, E. I.; Wang, T.; White, J. L.; Nadanaciva, S.; Sandin, R.; Mok, T. S. Dacomitinib Versus Gefitinib as First-Line Treatment for Patients with EGFR-Mutation-Positive Non-Small-Cell Lung Cancer (ARCHER 1050): a Randomised, Open-Label, Phase 3 Trial. Lancet Oncol. 2017, 18 (11), 1454-1466.

(19) Blakely, C. M.; Bivona, T. G. Resiliency of Lung Cancers to EGFR Inhibitor Treatment Unveiled, Offering Opportunities to Divide and Conquer EGFR Inhibitor Resistance. Cancer Discovery 2012, 2 (10), 872-875.

(20) Kobayashi, S.; Boggon, T. J.; Dayaram, T.; Jaenne, P. A.; Kocher, O.; Meyerson, M.; Johnson, B. E.; Eck, M. J.; Tenen, D. G.; Halmos, B. EGFR Mutation and Resistance of Non-Small-Cell Lung Cancer to Gefitinib. N. Engl. J. Med. 2005, 352 (8), 786-792.

(21) Wang, S.; Cang, S.; Liu, D. Third-Generation Inhibitors Targeting EGFR T790M Mutation in Advanced Non-Small Cell Lung Cancer. J. Hematol. Oncol. 2016, 9, 34/1-34/7.

(22) Cross, D. A. E.; Ashton, S. E.; Ghiorghiu, S.; Eberlein, C.; Nebhan, C. A.; Spitzler, P. J.; Orme, J. P.; Finlay, M. R. V.; Ward, R. A.; Mellor, M. J.; Hughes, G.; Rahi, A.; Jacobs, V. N.; Brewer, M. R.; Ichihara, E.; Sun, J.; Jin, H.; Ballard, P.; Al-Kadhimi, K.; Rowlinson, R.; Klinowska, T.; Richmond, G. H. P.; Cantarini, M.; Kim, D.-W.; Ranson, M. R.; Pao, W. AZD9291, an Irreversible EGFR TKI, Overcomes T790M-Mediated Resistance to EGFR Inhibitors in Lung Cancer. Cancer Discovery 2014, 4 (9), 1046-1061.

(23) Janne, P. A.; Yang, J. C.-H.; Kim, D.-W.; Planchard, D.; Ohe, Y.; Ramalingam, S. S.; Ahn, M.-J.; Kim, S.-W.; Su, W.-C.; Horn, L.; Haggstrom, D.; Felip, E.; Kim, J.-H.; Frewer, P.; Cantarini, M.; Brown, K. H.; Dickinson, P. A.; Ghiorghiu, S.; Ranson, M. AZD9291 in EGFR Inhibitor-Resistant Non-Small-Cell Lung Cancer. N. Engl. J. Med. 2015, 372 (18), 1689-1699.

(24) Mok, T. S.; Wu, Y. L.; Ahn, M. J.; Garassino, M. C.; Kim, H. R.; Ramalingam, S. S.; Shepherd, F. A.; He, Y.; Akamatsu, H.; Theelen, W. S. M. E.; Lee, C. K.; Sebastian, M.; Templeton, A.; Mann, H.; Marotti, M.; Ghiorghiu, S.; Papadimitrakopoulou, V. A. Osimertinib or Platinum-Pemetrexed in EGFR T790M-Positive Lung Cancer. N. Engl. J. Med. 2017, 376 (7), 629-640.

(25) Ortiz-Cuaran, S.; Scheffler, M.; Plenker, D.; Dahmen, 1.; Scheel, A. H.; Fernandez-Cuesta, L.; Meder, L.; Lovly, C. M.; Persigehl, T.; Merkelbach-Bruse, S.; Bos, M.; Michels, S.; Fischer, R.; Albus, K.; Koenig, K.; Schildhaus, H.-U.; Fassunke, J.; Ihle, M. A.; Pasternack, H.; Heydt, C.; Becker, C.; Altmueller, J.; Ji, H.; Mueller, C.; Florin, A.; Heuckmann, J. M.; Nuernberg, P.; Ansen, S.; Heukamp, L. C.; Berg, J.; Pao, W.; Peifer, M.; Buettner, R.; Wolf, J.; Thomas, R. K.; Sos, M. L. Heterogeneous Mechanisms of Primary and Acquired Resistance to Third-Generation EGFR Inhibitors. Clin. Cancer Res. 2016, 22 (19), 4837-4847.

(26) Song, H.-N.; Jung, K. S.; Yoo, K. H.; Cho, J.; Lee, J. Y.; Lim, S. H.; Kim, H. S.; Sun, J.-M.; Lee, S.-H.; Ahn, J. S.; Park, K.; Choi, Y.-L.; Park, W.; Ahn, M.-J. Acquired C797S Mutation upon Treatment with a T790M-Specific Third-Generation EGFR Inhibitor (HM61713) in Non-Small Cell Lung Cancer. J. Thorac. Oncol. 2016, 11 (4), No. e45e47.

(27) Thress, K. S.; Paweletz, C. P.; Felip, E.; Cho, B. C.; Stetson, D.; Dougherty, B.; Lai, Z.; Markovets, A.; Vivancos, A.; Kuang, Y.; Ercan, D.; Matthews, S. E.; Cantarini, M.; Barrett, J. C.; Janne, P. A.; Oxnard, G. R. Acquired EGFR C797S Mutation Mediates Resistance to AZD9291 in Non-Small Cell Lung Cancer Harboring EGFR T790M. Nat. Med. (N. Y., NY, U. S.) 2015, 21 (6), 560-562.

(28) Yang, Z.; Yang, N.; Ou, Q.; Xiang, Y.; Jiang, T.; Wu, X.; Bao, H.; Tong, X.; Wang, X.; Shao, Y. W.; Liu, Y.; Wang, Y.; Zhou, C. Investigating Novel Resistance Mechanisms to Third-Generation 
EGFR Tyrosine Kinase Inhibitor Osimertinib in Non-Small Cell Lung Cancer Patients. Clin. Cancer Res. 2018, 24 (13), 3097-3107.

(29) Yu, H. A.; Drilon, A. E.; Riely, G. J.; Tian, S. K.; Borsu, L.; Arcila, M. E.; Ladanyi, M. Acquired Resistance of EGFR-Mutant Lung Cancer to a T790M-Specific EGFR Inhibitor: Emergence of a Third Mutation (C797S) in the EGFR Tyrosine Kinase Domain. JAMA Oncol 2015, 1 (7), 982-984.

(30) Ramalingam, S. S.; Yang, J. C. H.; Lee, C. K.; Kurata, T.; Kim, D.-W.; John, T.; Nogami, N.; Ohe, Y.; Mann, H.; Rukazenkov, Y.; Ghiorghiu, S.; Stetson, D.; Markovets, A.; Carl Barrett, J.; Thress, K. S.; Jaenne, P. A. Osimertinib as First-Line Treatment of EGFR Mutation-Positive Advanced Non-Small-Cell Lung Cancer. J. Clin. Oncol. 2018, 36 (9), 841-849.

(31) Hei, Y. Y.; Shen, Y.; Wang, J.; Zhang, H.; Zhao, H. Y.; Xin, M.; Cao, Y. X.; Li, Y.; Zhang, S. Q. Synthesis and Evaluation of 2,9Disubstituted 8-Phenylthio/Phenylsulfinyl-9H-Purine as New EGFR Inhibitors. Bioorg. Med. Chem. 2018, 26 (8), 2173-2185.

(32) Chen, L.; Zhang, Y.; Liu, J.; Wang, W.; Li, X.; Zhao, L.; Wang, W.; Li, B. Novel 4-Arylaminoquinazoline Derivatives with (E)Propen-1-yl moiety as Potent EGFR Inhibitors with Enhanced Antiproliferative Activities Against Tumor Cells. Eur. J. Med. Chem. 2017, 138 (Supplement C), 689-697.

(33) Günther, M.; Lategahn, J.; Juchum, M.; Döring, E.; Keul, M.; Engel, J.; Tumbrink, H. L.; Rauh, D.; Laufer, S. Trisubstituted Pyridinylimidazoles as Potent Inhibitors of the Clinically Resistant L858R/T790M/C797S EGFR Mutant: Targeting of Both Hydrophobic Regions and the Phosphate Binding Site. J. Med. Chem. 2017, 60 (13), 5613-5637.

(34) Fukuda, T.; Umeki, T.; Tokushima, K.; Xiang, G.; Yoshida, Y.; Ishibashi, F.; Oku, Y.; Nishiya, N.; Uehara, Y.; Iwao, M. Design, Synthesis, and Evaluation of A-Ring-Modified Lamellarin $\mathrm{N}$ Analogues as Noncovalent Inhibitors of the EGFR T790M/L858R Mutant. Bioorg. Med. Chem. 2017, 25 (24), 6563-5680.

(35) Zhang, H.; Wang, J.; Shen, Y.; Wang, H. Y.; Duan, W. M.; Zhao, H. Y.; Hei, Y. Y.; Xin, M.; Cao, Y. X.; Zhang, S. Q. Discovery of 2,4,6-Trisubstitued Pyrido[3,4-d]pyrimidine Derivatives as new EGFR-TKIs. Eur. J. Med. Chem. 2018, 148, 221-237.

(36) Juchum, M.; Günther, M.; Döring, E.; Sievers-Engler, A.; Lämmerhofer, M.; Laufer, S. Trisubstituted Imidazoles with a Rigidized Hinge Binding Motif Act As Single Digit nM Inhibitors of Clinically Relevant EGFR L858R/T790M and L858R/T790M/ C797S Mutants: An Example of Target Hopping. J. Med. Chem. 2017, 60 (11), 4636-4656.

(37) Lu, X.; Zhang, T.; Zhu, S.-J.; Xun, Q.; Tong, L.; Hu, X.; Li, Y.; Chan, S.; Su, Y.; Sun, Y.; Chen, Y.; Ding, J.; Yun, C.-H.; Xie, H.; Ding, K. Discovery of JND3229 as a New EGFRC797S Mutant Inhibitor with In Vivo Monodrug Efficacy. ACS Med. Chem. Lett. 2018, 9 (11), $1123-1127$

(38) Hanan, E. J.; Baumgardner, M.; Bryan, M. C.; Chen, Y.; Eigenbrot, C.; Fan, P.; Gu, X. H.; La, H.; Malek, S.; Purkey, H. E.; Schaefer, G.; Schmidt, S.; Sideris, S.; Yen, I.; Yu, C.; Heffron, T. P. 4Aminoindazolyl-dihydrofuro[3,4-d]pyrimidines as Non-cCvalent Inhibitors of Mutant Epidermal Growth Factor Receptor Tyrosine Kinase. Bioorg. Med. Chem. Lett. 2016, 26 (2), 534-539.

(39) Heald, R.; Bowman, K. K.; Bryan, M. C.; Burdick, D.; Chan, B.; Chan, E.; Chen, Y.; Clausen, S.; Dominguez-Fernandez, B.; Eigenbrot, C.; Elliott, R.; Hanan, E. J.; Jackson, P.; Knight, J.; La, H.; Lainchbury, M.; Malek, S.; Mann, S.; Merchant, M.; Mortara, K.; Purkey, H.; Schaefer, G.; Schmidt, S.; Seward, E.; Sideris, S.; Shao, L.; Wang, S.; Yeap, K.; Yen, I.; Yu, C.; Heffron, T. P. Noncovalent Mutant Selective Epidermal Growth Factor Receptor Inhibitors: A Lead Optimization Case Study. J. Med. Chem. 2015, 58 (22), 8877-8895.

(40) Hanan, E. J.; Eigenbrot, C.; Bryan, M. C.; Burdick, D. J.; Chan, B. K.; Chen, Y.; Dotson, J.; Heald, R. A.; Jackson, P. S.; La, H.; Lainchbury, M. D.; Malek, S.; Purkey, H. E.; Schaefer, G.; Schmidt, S.; Seward, E. M.; Sideris, S.; Tam, C.; Wang, S.; Yeap, S. K.; Yen, I.; Yin, J.; Yu, C.; Zilberleyb, I.; Heffron, T. P. Discovery of Selective and Noncovalent Diaminopyrimidine-Based Inhibitors of Epidermal
Growth Factor Receptor Containing the T790M Resistance Mutation. J. Med. Chem. 2014, 57 (23), 10176-10191.

(41) Bryan, M. C.; Burdick, D. J.; Chan, B. K.; Chen, Y.; Clausen, S.; Dotson, J.; Eigenbrot, C.; Elliott, R.; Hanan, E. J.; Heald, R.; Jackson, P.; La, H.; Lainchbury, M.; Malek, S.; Mann, S. E.; Purkey, H. E.; Schaefer, G.; Schmidt, S.; Seward, E.; Sideris, S.; Wang, S.; Yen, I.; Yu, C.; Heffron, T. P. Pyridones as Highly Selective, Noncovalent Inhibitors of T790M Double Mutants of EGFR. ACS Med. Chem. Lett. 2016, 7 (1), 100-104.

(42) Park, H.; Jung, H.-Y.; Mah, S.; Hong, S. Discovery of EGF Receptor Inhibitors That Are Selective for the d746-750/T790M/ C797S Mutant through Structure-Based de Novo Design. Angew. Chem., Int. Ed. 2017, 56 (26), 7634-7638.

(43) Chan, B. K.; Hanan, E. J.; Bowman, K. K.; Bryan, M. C.; Burdick, D.; Chan, E.; Chen, Y.; Clausen, S.; Dela Vega, T.; Dotson, J.; Eigenbrot, C.; Elliott, R. L.; Heald, R. A.; Jackson, P. S.; Knight, J. D.; La, H.; Lainchbury, M. D.; Malek, S.; Purkey, H. E.; Schaefer, G.; Schmidt, S.; Seward, E. M.; Sideris, S.; Shao, L.; Wang, S.; Yeap, S. K.; Yen, I.; Yu, C.; Heffron, T. P. Discovery of a Noncovalent, MutantSelective Epidermal Growth Factor Receptor Inhibitor. J. Med. Chem. 2016, 59 (19), 9080-9093.

(44) Patel, H. M.; Pawara, R.; Ansari, A.; Noolvi, M.; Surana, S. Design and Synthesis of Quinazolinones as EGFR Inhibitors to Overcome EGFR Resistance Obstacle. Bioorg. Med. Chem. 2017, 25 (10), 2713-2723.

(45) Wang, S.; Song, Y.; Liu, D. EAI045: The Fourth-Generation EGFR Inhibitor Overcoming T790M and C797S resistance. Cancer Lett. 2017, 385, 51-54.

(46) Spellmon, N.; Li, C.; Yang, Z. Allosterically Targeting EGFR Drug-Resistance Gatekeeper Mutations. J. Thorac. Dis. 2017, 9 (7), $1756-1758$.

(47) Kannan, S.; Venkatachalam, G.; Lim, H. H.; Surana, U.; Verma, C. Conformational Landscape of the Epidermal Growth Factor Receptor Kinase Reveals a Mutant Specific Allosteric Pocket. Chemical Science 2018, 9 (23), 5212-5222.

(48) Caporuscio, F.; Tinivella, A.; Restelli, V.; Semrau, M. S.; Pinzi, L.; Storici, P.; Broggini, M.; Rastelli, G. Identification of SmallMolecule EGFR Allosteric Inhibitors by High-Throughput Docking. Future Med. Chem. 2018, 10 (13), 1545-1553.

(49) Zhao, P.; Yao, M. Y.; Zhu, S. J.; Chen, J. Y.; Yun, C. H. Crystal Structure of EGFR T790M/C797S/V948R in Complex with EAI045. Biochem. Biophys. Res. Commun. 2018, 502 (3), 332-337.

(50) To determine the kinase selectivity for a given compound, the "SelectScreen Kinase Profiling Services" from ThermoFisher was used. The activity of a compound was determined in biochemical assays using single concentration measurements. The results were provided as percent inhibition values. A compound displaying a percent inhibition value of greater $70 \%$ was defined as hit. Three different kinase panels were used ( 30 kinases, 238 kinases, and 393 kinases), and the lists of kinases for these repective panels are provided in Tables S5-S7. The EGFR ${ }^{\mathrm{L} 858 \mathrm{R} \text { T790M C797S }}$ kinase assay was used as positive control.

(51) Traxler, P.; Furet, P. Strategies Toward the Design of Novel and Selective Protein Tyrosine Kinase Inhibitors. Pharmacol. Ther. 1999, 82 (2-3), 195-206.

(52) Chai, J.-D.; Head-Gordon, M. Long-range Corrected Hybrid Density Functionals With Damped Atom-Atom Dispersion Corrections. Phys. Chem. Chem. Phys. 2008, 10 (44), 6615-6620.

(53) Alihodžić, S.; Bukvić, M.; Elenkov, I. J.; Hutinec, A.; Koštrun, S.; Pešić, D.; Saxty, G.; Tomašković, L.; Žiher, D. Current Trends in Macrocyclic Drug Discovery and Beyond-Ro5. Prog. Med. Chem. 2018, 57, 113-233.

(54) Whitty, A.; Viarengo, L. A.; Zhong, M. Progress Towards the Broad Use of Non-Peptide Synthetic Macrocycles in Drug Discovery. Org. Biomol. Chem. 2017, 15 (37), 7729-7735.

(55) Ermert, P. Design, Properties and Recent Application of Macrocycles in Medicinal Chemistry. Chimia 2017, 71 (10), 678702 . 
(56) Labute, P. LowModeMD - Implicit Low-Mode Velocity Filtering Applied to Conformational Search of Macrocycles and Protein Loops. J. Chem. Inf. Model. 2010, 50 (5), 792-800.

(57) Kamenik, A. S.; Lessel, U.; Fuchs, J. E.; Fox, T.; Liedl, K. R. Peptidic Macrocycles - Conformational Sampling and Thermodynamic Characterization. J. Chem. Inf. Model. 2018, 58 (5), 982-992.

(58) Klebl, B., Mueller, G., Hamacher, M., Eds. Protein Kinases as Drug Targets. Methods and Principles in Medicinal Chemistry; WileyVCH Verlag GmbH \& Co. KGaA: Weinheim, 2011; Vol. 49, 373 pp.

(59) Baell, J. B.; Nissink, J. W. M. Seven Year Itch: Pan-Assay Interference Compounds (PAINS) in 2017-Utility and Limitations. ACS Chem. Biol. 2018, 13 (1), 36-44.

(60) Baell, J. B.; Holloway, G. A. New Substructure Filters for Removal of Pan Assay Interference Compounds (PAINS) from Screening Libraries and for Their Exclusion in Bioassays. J. Med. Chem. 2010, 53 (7), 2719-2740.

(61) Hanan, E. J.; Eigenbrot, C.; Bryan, M. C.; Burdick, D. J.; Chan, B. K.; Chen, Y.; Dotson, J.; Heald, R. A.; Jackson, P. S.; La, H.; Lainchbury, M. D.; Malek, S.; Purkey, H. E.; Schaefer, G.; Schmidt, S.; Seward, E. M.; Sideris, S.; Tam, C.; Wang, S.; Yeap, S. K.; Yen, I.; Yin, J.; Yu, C.; Zilberleyb, I.; Heffron, T. P. Discovery of Selective and Noncovalent Diaminopyrimidine-Based Inhibitors of Epidermal Growth Factor Receptor Containing the T790M Resistance Mutation. J. Med. Chem. 2014, 57 (23), 10176-10191.

(62) Kabsch, W. XDS. Acta Crystallogr., Sect. D: Biol. Crystallogr. 2010, 66 (Pt 2), 125-132.

(63) Winn, M. D.; Ballard, C. C.; Cowtan, K. D.; Dodson, E. J.; Emsley, P.; Evans, P. R.; Keegan, R. M.; Krissinel, E. B.; Leslie, A. G. W.; McCoy, A.; McNicholas, S. J.; Murshudov, G. N.; Pannu, N. S.; Potterton, E. A.; Powell, H. R.; Read, R. J.; Vagin, A.; Wilson, K. S. Overview of the CCP4 Suite and Current Developments. Acta Crystallogr., Sect. D: Biol. Crystallogr. 2011, 67 (4), 235-242.

(64) Vagin, A. A.; Steiner, R. A.; Lebedev, A. A.; Potterton, L.; McNicholas, S.; Long, F.; Murshudov, G. N. REFMAC5 Dictionary: Organization of Prior Chemical Knowledge and Guidelines for its Use. Acta Crystallogr., Sect. D: Biol. Crystallogr. 2004, D60 (12,Pt. 1), 2184-2195.

(65) Luippold, A. H.; Arnhold, T.; Joerg, W.; Krueger, B.; Suessmuth, R. D. Application of a Rapid and Integrated Analysis System (RIAS) as a High-Throughput Processing Tool For In Vitro ADME Samples by Liquid Chromatography/tandem Mass Spectrometry. J. Biomol. Screening 2011, 16 (3), 370-377. 